Université de Montréal

\title{
Escherichia coli STb toxin induces apoptosis in intestinal epithelial cell lines
}

\author{
par \\ Hamida Claudia Syed \\ Département de pathologie et microbiologie \\ Faculté de médecine vétérinaire
}

Mémoire présenté à la Faculté de médecine vétérinaire en vue de l'obtention du grade de maître ès sciences (M.Sc.) en sciences vétérinaires option microbiologie

Décembre 2011

(C) Hamida Claudia Syed, 2011 
Université de Montréal

Faculté de médecine vétérinaire

Ce mémoire intitulé :

\section{Escherichia coli STb toxin induces apoptosis in intestinal epithelial cell lines}

présenté par :

Hamida Claudia Syed

a été évalué par un jury composé des personnes suivantes :

Mario Jacques, président-rapporteur

J. Daniel Dubreuil, directeur de recherche

Mariela Segura, membre du jury 
RÉSUMÉ 
La toxine stable à la chaleur de type $\mathrm{b}(\mathrm{STb})$ est une des toxines produites par les souches Enterotoxigenic Escherichia coli (ETEC) impliquée dans le développement de la diarrhée. Une étude antérieure par Goncalves et al. (2009) a démontré que les cellules ayant internalisé la toxine STb démontraient une morphologie qui rappelle l'apoptose. Le changement du potentiel membranaire observé par Goncalves et al. (2009) nous a incité à vérifier la capacité de la toxine STb à induire l'apoptose des cellules HRT-18 et IEC-18 par la voie intrinsèque. Les cellules HRT-18 et IEC-18 ont été traitées avec de la toxine purifiée pour une durée de 24 heures puis ells ont été récoltées et examinées pour des caratéristiques de l'apoptose. L'activation des caspases-9 et -3, mais pas de la caspase-8, a été observée dans les deux lignées cellulaires à l'aide des substrats fluorescents spécifiques pour chaque caspase. L'ADN extrait des cellules HRT-18 et IEC-18 a révélé une fragmentation lorsque migré sur gel d'agarose. La condensation et la fragmentation des noyaux ont été observées en microscopie à fluorescence suite à une coloration de l'ADN au Hoechst 33342. Les indices apoptotiques des cellules HRT-18 et IEC-18 traitées avec des quantités croissantes de STb montrent une doseréponse pour les deux lignées. L'activation de la caspase-9 est une indication que la voie intrinsèque de l'apoptose est activée dans les cellules HRT-18 et IEC-18. L'absence de l'activation de la caspase-8 démontre que la voie extrinsèque n'est pas impliquée dans la mort cellulaire médiée par STb. 
Mots clés: apoptose, caspase, mort cellulaire, fragmentation de l'ADN, ETEC, fragmentation nucléaire, toxine $\mathrm{STb}$. 
ABSTRACT 
Heat-stable toxin $\mathrm{b}(\mathrm{STb})$ is one of the toxins produced by Enterotoxigenic Escherichia coli (ETEC) strains implicated in the development of diarrhea. A previous study conducted by Goncalves et al. (2009) showed that cells having internalized STb toxin demonstrated apoptotic-like morphology. The change in the mitochondrial membrane potential observed by Goncalves et al. (2009) prompted us to verify the ability of STb toxin to induce apoptosis via the intrinsic pathway in HRT-18 and IEC-18 cells. Both cell lines were treated with purified $\mathrm{STb}$ toxin for a period of 24 hours, harvested, and examined for apoptotic features. Activation of caspases- 9 and -3 , but not -8 , was observed in HRT-18 and IEC-18 cells as determined with the use of fluorescent substrates specific to each caspase. Extracted DNA revealed DNA laddering when migrated on agarose gels. Nuclear condensation and fragmentation of Hoechst 33342 stained DNA of HRT-18 and IEC-18 cells were visualized by fluorescence microscopy. Apoptotic indexes of HRT-18 and IEC-18 cells treated with increasing amounts of $\mathrm{STb}$ toxin revealed dose-dependent responses in both cell lines. The activation of caspase- 9 is an indication of the intrinsic pathway being activated in HRT-18 and IEC-18 cells by STb toxin. The lack of caspase- 8 activation demonstrates that the extrinsic pathway of apoptosis is not involved in the programmed cell death mediated by STb.

Key words: apoptosis, caspase, cell death, DNA laddering, ETEC, nuclear fragmentation, STb toxin. 


\section{TABLE OF CONTENTS}

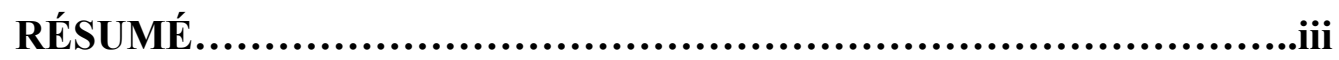

ABSTRACT ..............................................................

TABLE OF CONTENTS..................................................viii

LIST OF FIGURES......................................................

LIST OF ABBREVIATIONS...........................................xii

ACKNOWLEDGMENTS ...............................................xvii

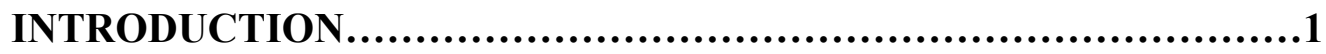

REVIEW OF THE LITERATURE.......................................4

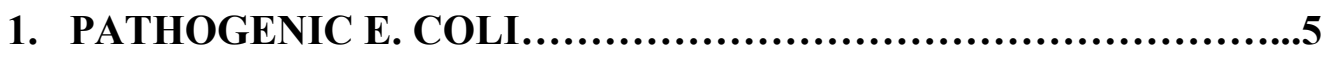

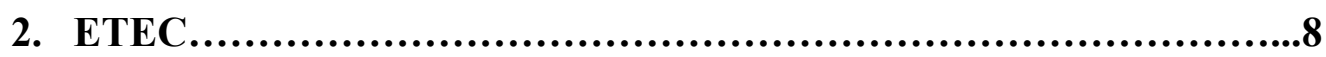

2.1 ETEC VIRULENCE FACTORS......................................10

2.2 COLONIZATION FACTORS............................................10

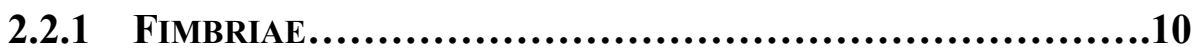

2.2.2 AFIMBRIAE................................................

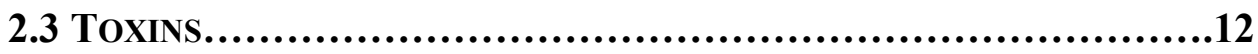

2.3.1. LT TOXIN...................................................12

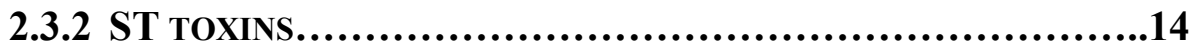

2.3.2.1 EAST-1 .............................................14

2.3.2.2 STa ToXIN.......................................15

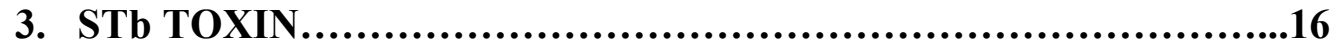

3.1 GENETICS.....................................................17

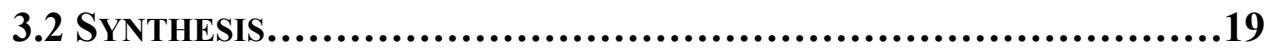

3.3 BIOCHEMICAL STRUCTURE........................................22

3.4 RECEPTOR OF STb TOXIN.........................................24

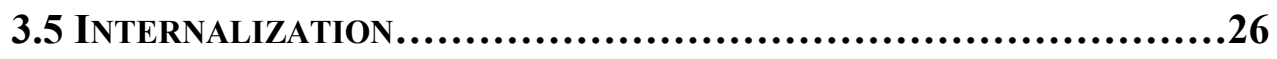

3.6 MODE OF ACTION.................................................28

3.7 IMMUNOGENIC POTENTIAL..........................................32 


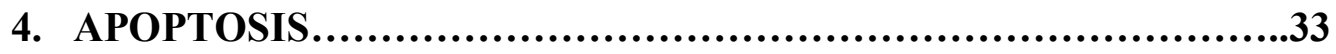

4.1 GENETIC REGULATION OF APOPTOSIS.................................36

4.2 BCL-2 FAMILY PROTEINS.............................................39

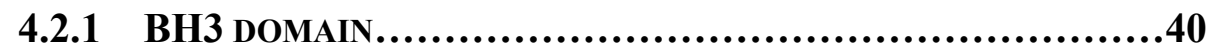

4.3 CASPASES.............................................................42

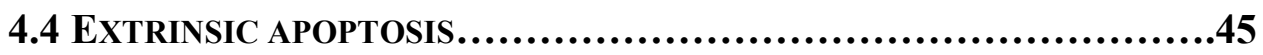

4.5 INTRINSIC APOPTOSIS.............................................46

5. IONS IMPLICATED IN APOPTOSIS..............................49

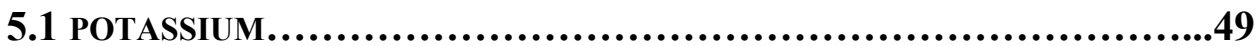

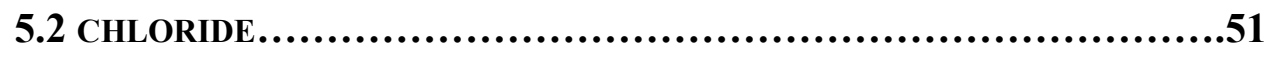

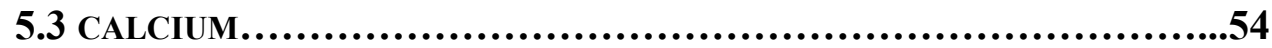

6. TOXINS INDUCING APOPTOSIS..............................56

6.1 ENTEROTOXINS................................................56

6.1.1 CLOSTRIDIUM DIFFICILE TOXIN A...........................56

6.1.2 ESCHERICHIA COLI LT TOXIN..................................57

6.2 PORE-FORMING ENTEROTOXINS...................................58

6.2.1 VIBRIO CHOLERAE CYTOLYSIN................................58

6.2.2 CLOSTRIDIUM PERFRINGENS ENTEROTOXIN....................58

6.3 PORE-FORMING TOXINS.............................................59

6.3.1 STAPHYLOCOCCUS AUREUS $\alpha$-TOXIN...........................59

6.3.2 HELICOBACTER PYLORI VACA...................................60

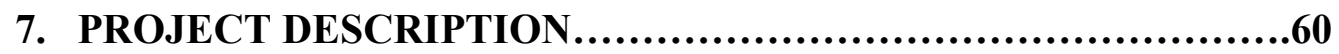

METHODOLOGY AND RESULTS.................................62

Article:

Escherichia coli STb toxin induces apoptosis in intestinal epithelial

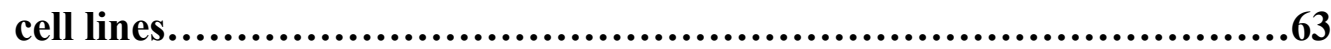

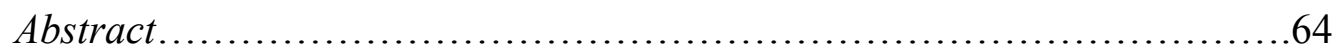

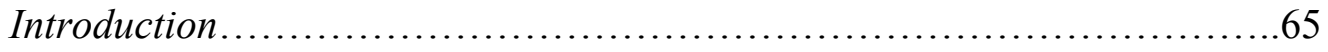

Materials and methods....................................................69

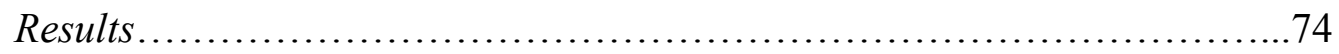


Discussion ..................................................... 76

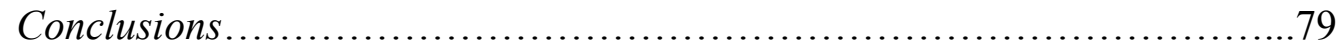

References..................................................... 80

Acknowledgments...............................................86

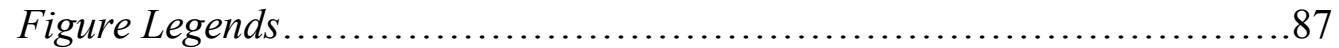

Figures...................................................... 89

DISCUSSION.................................................................94

1. CELl-TYPE AND APOPTOSIS....................................95

2. CASPASE INVOLVEMENT IN STB-MEDIATED APOPTOSIS.............97

3. FRAGMENTATION OF DNA AND NUCLEI BY STB...................99

4. APOPTOSIS INDUCED BY STB IS DOSE-DEPENDENT....................100

5. APOPTOSIS INDUCTION BY ENTERIC PATHOGENS..................101

CONCLUSION...................................................................104

FUTURE DIRECTIONS.............................................107

1. Cell-Cycle analysis...............................................108

2. INVOLVEMENT OF OLIGOMERIZATION IN APOPTOSIS INDUCTION...109

3. APOPTOSIS IN IN VIVO CONDITIONS...............................110

4. DEVELOPMENT OF A LOCAL INHIBITOR OF APOPTOSIS..............110

REFERENCES...................................................112 


\section{LIST OF FIGURES}

\section{REVIEW OF THE LITERATURE}

Figure 1: Mode of action of ETEC bacteria.............................

Figure 2: Synthesis of STb toxin...................................20

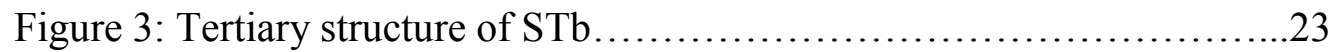

Figure 4: Proposed mode of action of STb..............................29

Figure 5: Comparison of the cellular death pathway in C. elegans and

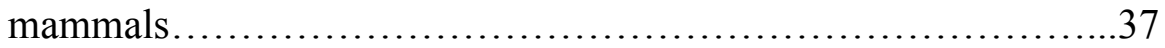

Figure 6: BCL-2 family proteins.................................40

Figure 7: Extrinsic and intrinsic apoptosis ..........................48

Figure 8: Cell shrinkage during apoptosis............................53

\section{ARTICLE}

Figure 1: Caspase activation in HRT-18 cells treated with STb.............89

Figure 2: Caspase activation in IEC-18 cells treated with STb..............90

Figure 3: Gel electrophoresis DNA extracted from HRT-18 and IEC-18 cells

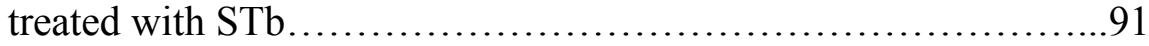

Figure 4: Condensed and fragmented nuclei in HRT-18 and IEC-18 cells....92

Figure 5: STb induces a dose-dependent apoptosis in HRT-18 and IEC-18 cells. 


\section{LIST OF ABBREVIATIONS}

$\mathrm{AAA}^{+} \quad$ ATPase domain

AAF Aggregative adherence fimbriae

AB toxin $\quad$ A: activity domain; $B$ : binding domain

Ac

Acetyl

ADN Acide déoxyribonucléique

ADP Adenosine diphosphate

$\mathrm{A} / \mathrm{E}$

Attaching and effacing

Afa afimbriae adhesins

AGS Gastric epithelial cells

AIDA-I Adhesin Involved in Diffuse Adherence

Ala

Alanine

AMP Adenosine monophosphate

APAF-1 Apoptosis Protease Activating Factor-1

Arg Arginine

Asp Aspartic acid

AVD Apoptotic Volume Decrease

BAK Bcl-2 homologous antagonist/killer

BAX Bcl-2-associated $X$ protein

BCL-2 B-cell lymphoma 2

$\mathrm{BH} \quad$ B-cell lymphoma 2 homology domain

BID BH3 interacting-domain death agonist

BIK Bcl-2-interacting killer

BIM Bcl-2-like protein 11

cAMP cylic AMP

CARD Caspase Activation and Recruitment Domain

CD Circular Dichroism

CED-3 Cell Death Protein 3

CED-4 Cell Death Protein 4 
CED-9 Cell Death Protein 9

CFA/I Colonization Factor Antigen I

CFTR Cystic fibrosis transmembrane conductance regulator

cGMP cyclic GMP

CHAPS 3-[(3-cholamidopropyl)dimethylammonio]-1-propanesulfonate

Cif Cycle inhibiting factor

CPE Clostridium perfringens enterotoxin

CS Coli Surface Antigen

CT Cholera toxin

DAEC Diffusely Adherent Escherichia coli

DAF Decay Accelerating Factor

DEVD Aspartic Acid - Glutamic Acid - Valine - Aspartic Acid

DFF DNA Fragmentation Factor

DMEM Dulbecco’s Modified Eagle Medium

DNA Deoxyribonucleic acid

DsbA Disulfide-bond A oxidoreductase

DsbC Disulfide-bond C oxidoreductase

DISC Death-Inducing Signaling Pathway

DTT Dithiothreitol

EAEC Enteroaggregative Escherichia coli

EAST-1 Enteroaggregative heat-stable toxin 1

EDTA Ethylene diamine tetraacetic acid

EGL-1 Egg-Laying Protein 1

EHEC Enterohemorrhagic Escherichia coli

EIEC Enteroinvasive Escherichia coli

ELISA Enzyme-linked immunosorbent assay

EPEC Enteropathogenic Escherichia coli

Esp E. coli secreted protein

ETEC Enterotoxigenic Escherichia coli

FADD Fas Associated Death Domain

FasL Fas Ligand 


\begin{tabular}{|c|c|}
\hline FasR & Fas Receptor \\
\hline FBS & Fetal Bovine Serum \\
\hline FITC & Fluorescein isothiocyanate \\
\hline G protein & guanine nucleotide-binding protein \\
\hline GC-C & guanylate cyclase type $\mathrm{C}$ \\
\hline Gly & Glycine \\
\hline GM1 & Monosialotetrahexosylganglioside \\
\hline GMP & Guanosine monophosphate \\
\hline GTP & Guanosine triphosphate \\
\hline HEPES & 4-(2-hydroxyethyl)-1-piperazineethanesulfonic acid \\
\hline HRT-18 & Human Colon Tumour Cells \\
\hline IAP & Inhibitor of Apoptosis Protein \\
\hline ICE & Interleukin- $1 \beta$ Converting Enzyme \\
\hline IEC-18 & Rat Ileum Epithelial Cells \\
\hline Ile & Isoleucine \\
\hline IPTG & Isopropyl- $\beta$-D-thio-galactoside \\
\hline IS & Insertion Sequence \\
\hline \multirow[t]{2}{*}{$\mathrm{JC}-1$} & 5,5',6,6'-tetrachloro-1,1',3,3'- \\
\hline & tetraethylbenzimidazolylcarbocyanine iodide \\
\hline $\mathrm{KLH}$ & Keyhole Limpet Hemacyanin \\
\hline LEE & Locus of enterocyte effacement \\
\hline \multirow[t]{2}{*}{ LExD } & Leucine - Glutamic Acid - Threonine or Histidine - \\
\hline & Aspartic Acid \\
\hline $\mathrm{LT}$ & Heat-labile \\
\hline Lys & Lysine \\
\hline MBP & Maltose-binding Protein \\
\hline MBP-STb & Maltose-binding protein - Heat stable enterotoxin $b$ \\
\hline Met & Methionine \\
\hline mRNA & messenger Ribonucleic acid \\
\hline NMDA & N-methyl-d-aspartate \\
\hline NMEC & Neonatal Meningitis Escherichia coli \\
\hline
\end{tabular}




$\begin{array}{ll}\text { nmol } & \text { nanomole } \\ \text { NMR } & \text { Nuclear Magnetic Resonance } \\ \text { NMDGCl } & \text { N-methyl-D-glucamine hydrochloride } \\ \text { OMM } & \text { outer mitochondrial membrane } \\ \text { OmpF } & \text { Outer membrane protein F } \\ \text { ORF } & \text { Open Reading Frame } \\ \text { PARP-1 } & \text { Poly [ADP-ribose] polymerase 1 } \\ \text { PBS } & \text { Phosphate Buffered Saline } \\ \text { Pen/Strep } & \text { Penicillin/Streptomcyin } \\ \text { Pet } & \text { Plasmid-encoded toxin } \\ \text { Phe } & \text { Phenylalanine } \\ \text { PI } & \text { Propidium Iodide } \\ \text { PMSF } & \text { phenylmethylsulfonyl fluoride } \\ \text { PTP } & \text { permeability transition pore } \\ \text { Rb } & \text { Retinoblastoma protein } \\ \text { RP-HPLC } & \text { Reverse Phase - High Performance Liquid Chromatography } \\ \text { RPMI } & \text { Roswell Park Memorial Institute } \\ \text { SDS-PAGE } & \text { sodium dodecyl sulfate polyacrylamide gel electrophoresis } \\ \text { SepA } & \text { serine-protease autotransporter } \\ \text { ShET1 } & \text { Shigella enterotoxin 1 } \\ \text { SMAC } & \text { Small mitochondria-derived activator of caspases } \\ \text { ST } & \text { Heat-stable } \\ \text { STa } & \text { Heat-stable enterotoxin a } \\ \text { STb } & \text { Heat-stable enterotoxin b } \\ \text { Stx } & \text { Shiga toxin } \\ \text { tBID } & \text { Truncated BID } \\ \text { TLR-4 } & \text { Toll-like receptor 4 } \\ \text { TNF } & \text { Tumour Necrosis Factor } \\ \text { TNFR } & \text { Tumour Necrosis Factor Receptor } \\ \text { TolC } & \text { Outer membrane channel protein } \\ \text { TRADD } & \text { TNF receptor-associated death domain } \\ \text { PRA } & \end{array}$


TUNEL Terminal deoxynucleotidyl transferase dUTP nick end labeling

T3SS Type 3 Secretion System

TxA Clostridium difficile toxin A

Tyr Tyrosine

UPEC Uropathogenic Escherichia coli

VacA Helicobacter pylori vacuolating toxin A

Val Valine

VCC Vibrio cholerae cytolysin

WD40 Sequence of $\sim 40$ amino acids ending with Tryptophan Aspartic Acid 


\section{ACKNOWLEDGMENTS}

I would like to thank first and foremost my director, Dr. J. Daniel Dubreuil, for welcoming me into his lab and giving me the opportunity to work on this project. Ce fut un véritable plaisir d'être étudiante sous ta direction, merci pour ta disponibilité, ton appui et ton implication dans mon projet. Merci de m’avoir donné la possibilité de présenter mes résultats à la CSM et de publier un chapitre de livre pour la SFET. Surtout merci pour avoir cru en moi tout au long de ma maîtrise.

I would like to thank members of my graduate committee, Dr. Michaël Mourez and Dr. Mariela Segura, for their advice and interest in my project, and for being there whenever I needed them. Thank you to Dr. Segura for accepting to correct my thesis as a jury member.

Thank you to my lab members Clément Mukiza, Cristina Paiva de Sousa, and Makrem Arfaoui for making life in the lab fun! As well, thank you to past student Marie-Astrid Albert for helping me find my footing in the Dubreuil lab.

Thank you to Samuel-Mohammed Chekabab (Simo) for encouraging me to broaden my horizons scientifically and for giving me the chance to work on his manuscript, but mostly, thank you for your friendship. 
Thank you to Dr. Mario Jacques for accepting to act as my reporting president for the correction of this thesis.

Thank you to Dr. Carl Gagnon and his post-docs Dr. Chantal Provost and Dr. Christian Savard for their insightful discussions on apoptosis and for helping me learn the ins and outs of fluorescence microscopy, a technique so useful to my project.

Thank you to my parents and my brothers for understanding the demands of my life as a graduate student, their continued support through my Master's degree, and for encouraging me during the difficult periods. 
INTRODUCTION 
Enterotoxigenic Escherichia coli (ETEC) bacteria constitute an important cause of diarrhea in children under the age of 5 years old residing in developing countries. Tourists from industrialized nations visiting these countries are also susceptible to the diarrhea mediated by ETEC strains (Okoh et al., 2008). In addition to inducing diarrhea in Man, ETEC causes diarrhea in animals, particularly in swine (Nagy et al., 2005).

The virulence factors produced by ETEC are mainly adhesins and enterotoxins. Heat-stable enterotoxin $b(\mathrm{STb})$ is one of the toxins produced by ETEC and is most commonly associated with porcine diarrhea (Dubreuil, 2008). Aside from causing diarrhea, STb induces morphological changes at the histological and cellular levels. Intestines exposed to STb toxin revealed shortening and atrophy of villi as well as a reduction of mucosal surfaces (Rose et al., 1987). The formation of non-specific pores has been observed in brush border membrane vesicles treated with pure toxin (Goncalves et al., 2007). Cultured cells having internalized STb displayed apoptotic-like morphology (Goncalves et al., 2009).

The induction of apoptosis of intestinal epithelial cells by toxins produced by enteric pathogens such as Clostridium perfringens (Chakrabarti et al., 2005), Clostridium difficile (Carneiro et al., 2006), and Vibrio cholerae (Saka et al., 2008) has been reported. 
Programmed cell death has been proposed as a mechanism to gain access to underlying mucosa (Hausmann, 2010) to promote colonization of the gut by enteric pathogens (Lupp et al., 2007), thus contributing to the development of infection mediated by enteric pathogens.

The thesis presented here describes the mechanism employed by STb toxin to induce apoptosis in intestinal epithelial cells and the implication of this phenomenon in the pathogenesis of $\mathrm{STb}^{+}$ETEC strains. 
REVIEW OF THE LITERATURE 


\section{PATHOGENIC E. COLI}

Pathogenic E. coli are commensal strains which have acquired genes coding for virulence factors responsible for the induction of illnesses and the adaptation of $E$. coli to broader ecological niches. The virulence factors allowing E. coli to modulate the development of illnesses consist of adhesins, toxins, secretion systems, invasins, and iron acquisition systems (Johnson et al., 2009). Genes coding for these virulence factors are usually carried on mobile genetic elements such as transposons, plasmids, and pathogenicity islands which are transmitted by DNA transfer mechanisms such as conjugation, transformation, and transduction (Kaper et al., 2004). Pathogenic E. coli constitute important causes of extra-intestinal and intestinal infections. Meningitis, urinary infections, septicemia, and pneumonia are examples of the extra-intestinal ailments caused by extra-intestinal pathogenic E. coli Neonatal Meningitis Escherichia coli (NMEC) and Uropathogenic Escherichia coli (UPEC). Intestinal infections mediated by pathogenic E. coli consist in the development of diarrhea (Croxen et al., 2010). The six pathotypes implicated in the promotion of diarrhea are classified according to the combination of virulence factors they express and can be regrouped as follows: Enteroaggregative Escherichia coli (EAEC), Enteroinvasive Escherichia coli (EIEC), Enterohemorrhagic Escherichia coli (EHEC), Enteropathogenic Escherichia coli (EPEC), Diffusely Adherent Escherichia coli (DAEC), and Enterotoxigenic Escherichia coli (ETEC) (Johnson et al., 2009). 
EAEC possess the particularity of forming aggregates appearing as stacked bricks while adhering to intestinal cells. The formation of aggregates is mediated by the Aggregative adherence fimbriae (AAF), an adhesin type which is also implicated in the formation of biofilms with intestinal mucin. Aside from AAF, the EAEC pathotype secretes toxins such as Plasmidencoded toxin (Pet), Shigella enterotoxin 1 (ShET1), and Enteroaggregative heat-stable toxin 1 (EAST-1), all of which are implicated in the secretion of electrolytes and water (Harrington et al., 2006).

The EIEC pathotype is similar to Shigella and distinguishes itself from the other intestinal pathotypes by its ability to invade host cells due to the expression of Ipa invasins, effector proteins secreted by the Type 3 Secretion System (T3SS). Invasion of host cells is followed by vacuole lysis, intracellular multiplication, and colonization of adjacent cells. In addition to invasins, EIEC possesses other virulence factors such as the serine-protease autotransporter (SepA) and ShET1 which contribute to the cytotoxicity caused by these bacteria. As EIEC is similar to Shigella, the diarrhea mediated by this pathotype can be likened to the shigellosis elaborated by Shigella sp. (Parsot, 2005).

EHEC bacteria produce attaching and effacing (A/E) lesions and carry the locus of enterocyte effacement (LEE) pathogenicity island similarly to the 
EPEC pathotype. The production of Stx toxins by EHEC, however, is a characteristic which distinguishes this pathotype from EPEC. The bloody diarrhea development by EHEC is dependent on the expression of the AB Shiga-like toxin (also called verocytotoxin). EHEC bacteria are also responsible for the induction of hemolytic-uremic syndrome (Schmidt, 2010). Serotype $\mathrm{O} 157$ is the most common member of the EHEC pathotype implicated in the development of diarrhea (Pennington, 2010).

As previously stated, EPEC carry the LEE and produce A/E lesions in the intestine. The histopathology of $\mathrm{A} / \mathrm{E}$ lesions is the result of intimate bacterial adherence, microvilli effacement, and the accumulation of polymerized actin beneath adherent bacteria giving rise to pedestal formation. Pedestal formation is mediated by the expression of intimin, which is implicated in intimate adherence of EPEC to host cells, Tir, the translocated receptor of intimin, and Escherichia coli secreted proteins (Esp), effector proteins secreted by T3SS responsible for disrupting the epithelium (Garmendia et al., 2005).

DAEC are characterized by the diffuse adherent pattern they exhibit on Hep-2 and HeLa cells (Nataro et al., 1987). Diffuse adherence is mediated by the expression of F1845, afimbriae adhesins (Afa), and Adhesin Involved in Diffuse Adherence (AIDA-I). The fimbriae F1845 interacts with its receptor Decay Accelerating Factor (DAF) causing the formation of long cellular extensions of the host cell around the bacteria (Servin, 2005). 


\section{ETEC}

ETEC bacteria are an important cause of diarrhea in children under the age of 5 years residing in developing countries as well as in travelers from industrialized countries (Nagy et al., 2005). ETEC strains are responsible for 210 million cases of diarrhea annually in Man (Kaper et al., 2004). Poor sanitation practices and an inadequate clean water supply in developing countries are responsible for the high contamination level of water with pathogenic bacteria such as ETEC, thus explaining the prevalence of ETECmediated diarrhea in Man in these countries. Bangladesh, Mexico, Peru, Egypt, Argentina, and Nicaragua are among the developing countries plagued by ETEC-mediated diarrhea (Qadri et al., 2005). In addition to targeting Man, ETEC bacteria also induce diarrhea in farm animals such as swine and calves (Nagy et al., 2005). The susceptibility of swine to ETEC will vary according to age: piglets younger than one week experience higher mortality rates than piglets older than one week. Moreover, ETEC triggers weight loss and growth retards in piglets older than one week indicating the age of the animal influences on the outcome of the disease developed (Dubreuil, 2008). As the swine commonly infected with ETEC are destined to the porcine industry, morbidity and mortality in these animals caused by ETEC constitute an important source of financial losses in the porcine industry (Nagy et al., 1999).

The development of diarrhea by ETEC depends on the expression of both colonization factors and toxin. The ingestion of ETEC bacteria through 
contaminated food and water is the first step in the mediation of diarrhea (Okoh et al., 2008), and is followed by bacterial adhesion to the intestine resulting from the interaction between colonization factors and their receptors at the surface of enterocytes. Bacteria colonize the intestine and produce, in proximity to enterocytes, heat-labile (LT) and heat-stable (ST) toxins responsible for the induction of diarrhea characterized by the secretion of electrolytes and water (Okoh et al., 2008) (Figure 1).

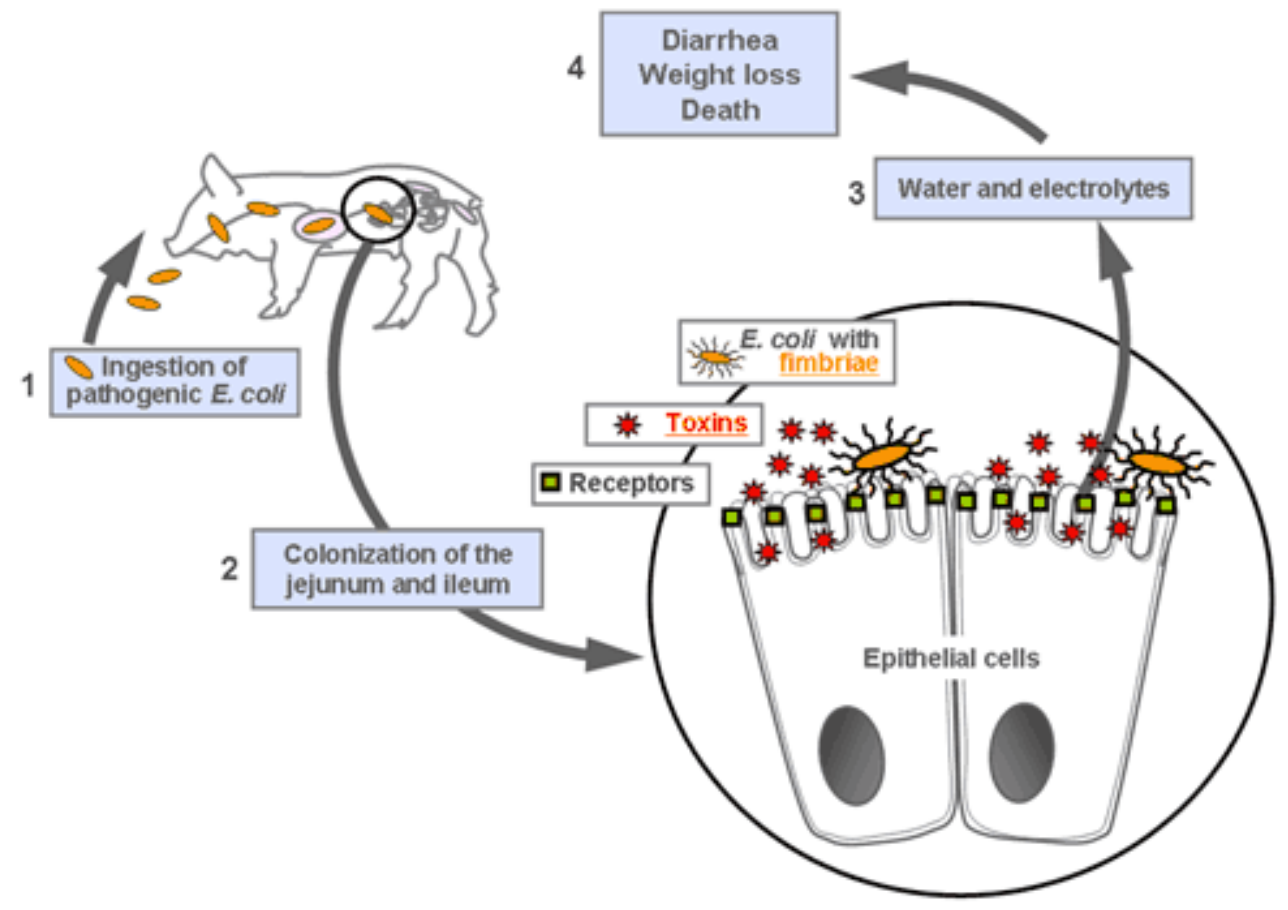

Figure 1: Mode of action of ETEC bacteria. 1. ETEC bacteria are ingested via contaminated food and water. 2. ETEC colonize the intestine with the help of adhesins, this is step is followed by the production of toxins. 3. Toxins stimulate the secretion of water and electrolytes. 4. Diarrhea, weight loss, and death of piglets ensue. (www.ecl-lab.ca) 


\subsection{ETEC VIRULENCE FACTORS}

Colonization factors and enterotoxins are the virulence factors associated with the ETEC pathotype. The genes coding for these virulence factors are carried on plasmids which also carry antibiotic resistance genes (Fairbrother et al., 2005).

\subsection{COLONIZATION FACTORS}

Colonization factors are protein structures expressed at the bacterial surface which play a role in the development of the pathogenesis caused by ETEC. Abolishment of colonization factors results in bacteria being unable to attach and colonize the intestine suggesting that colonization factors are essential to the progression of the diarrhea mediated by ETEC. Fimbriae constitute the most common colonization factor expressed by ETEC bacteria, however, the presence of afimbriae colonization factors has also been reported (Gaastra et al., 1996).

\subsubsection{FIMBRIAE}

ETEC fimbriae are proteinaecous filaments composed of minor and major subunits, the latter being of variable molecular masses and essential to the function of adhesion (Gaastra et al., 1996). The operons coding for fimbriae are generally carried on large plasmids and are composed of genes coding for 
the major and minor subunits of the fimbriae as well as the proteins implicated in their transport and assembly (Turner et al., 2006). The expression of fimbriae is regulated by phase variation mechanisms reflecting changes in environmental conditions such as $\mathrm{pH}$ and temperature, thus, allowing ETEC bacteria to adapt to such changes (Nagy et al., 1999).

The naming nomenclature of colonization factors is based on host tropism: animal colonization factors are assigned "F" (Turner et al., 2006) while human colonization factors are called Colonization Factor Antigen I (CFA/I) and coli surface antigens (CS) (Gaastra et al., 1996). The fimbriae F4 (K88), F5 (K99), F6 (987P), F41, F42, F165, F17 and F18 are commonly associated with animal strains (Nagy et al., 1999), with F4 and F18 being most prevalent in post-weaning diarrhea in piglets (Fairbrother et al., 2005).

\subsubsection{AFIMBRIAE}

The Adhesin Involved in Diffuse Adhesion (AIDA-I) belongs to the family of autotransporters anchored to the external membrane of bacteria (Benz et al., 1992) and is responsible for diffuse adherence of bacteria to host cells (Benz et al., 1989). AIDA-I has been identified as a potential adhesin in porcine ETEC strains (Ravi et al., 2007) expressing the fimbriae F18 associated with postweaning diarrhea (Niewerth et al., 2001). The gene coding for AIDA-I is prevalent in diarrheagenic strains carrying the gene coding for STb toxin 
(Ngeleka et al., 2003). Thus far, AIDA-I has not been isolated from strains originating from animals other than swine (Niewerth et al., 2001).

\subsection{TOXINS}

Toxins elaborated by ETEC strains are classed according to their resistance to heat and their molecular masses. Heat-labile toxins (LT) are sensitive to treatments to heat and possess high molecular masses. Heat-stable toxins (ST), on the other hand, are resistant to treatments to heat and have low molecular masses. LT toxins are subdivided as LT-I and LT-II toxins while ST toxins consist of STa, STb, and EAST-1. Toxins are produced at a later stage in the development of diarrhea and are responsible for the secretion of water and electrolytes.

\subsubsection{LT TOXIN}

LT toxin was first isolated from a pathogenic porcine strain in 1969 by Gyles and Barnum (Gyles et al., 1969) and has been shown to induce diarrhea in Man (Qadri et al., 2005) and in animals (Nagy et al., 2005). LT has also been associated with severe diarrhea and septicemia in piglets (Berberov et al., 2004). LT toxin is an $84 \mathrm{kDa} \mathrm{AB}$ toxin composed of one A subunit and five $\mathrm{B}$ subunits linked to each other by a disulfide bonds (Sixma et al., 1991). The A subunit of the toxin is an ADP-ribosyl transferase implicated in the 
development of diarrhea (Sixma et al., 1993). The B subunits are responsible for binding the ganglioside GM1 which constitutes the receptor of the toxin (Spangler, 1992). The LT-I and LT-II forms of the LT toxin differ in the B subunits they possess: a homology of $57 \%$ has been reported between the B subunits shared by LT-I and LT-II (Pickett et al., 1987). Of the two, LT-I is most commonly associated with animal and human ETEC strains. A homology of 55\% has been reported between LT and cholera toxin (CT) suggesting they are conserved and possess similar modes of actions (Pickett et al., 1989).

In order to cause diarrhea, LT first binds the GM1 ganglioside present at the surface of enterocytes via the B subunits (Griffiths et al., 1986, Tsuji et al., 1985). Receptor binding is followed by internalization of LT into vesicles which are retrograde transported to the Golgi apparatus and endoplasmic reticulum (Rappuoli et al., 1999). Proteolytic cleavage of the A subunit into $A_{1}$ and $A_{2}$ domains (Lencer et al., 1997) occurs and is followed by the translocation of the $A_{1}$ domain into the cytosol. The $A_{1}$ domain ADPribosylates the $\alpha$-unit of the $G_{\text {s }}$ protein, the $G$ protein regulating the activity of adenylate cyclase, resulting in the permanent activation of adenylate cyclase (Rappuoli et al., 1999) which in turn causes abnormal increases in cyclic AMP (cAMP) levels (Nataro et al., 1998). Augmented cAMP levels are followed by the activation of cAMP-dependent protein kinase A and the phosphorylation of chloride channels such as Cystic fibrosis transmembrane conductance regulator (CFTR). This leads to chloride secretion from crypt epithelial cells 
and the inhibition of sodium absorption by villous enterocytes resulting in secretory diarrhea (Spangler, 1992).

\subsubsection{ST ToxINS}

ST toxins are heat-stable toxins produced ETEC strains. EAST-1, STa, and $\mathrm{STb}$ are the toxins belonging to this group.

\subsubsection{EAST-1}

EAST-1 was first isolated from the strain EAEC 17-2 (Savarino et al., 1991) and later isolated from human and animal ETEC strains (Veilleux et al., 2006). EAST-1 causes an increase in cyclic GMP (cGMP) levels in enterocytes similarly to STa toxin (discussed below). As EAST-1 bears structural similarities to STa toxin, it is believed that EAST-1 possesses a similar mode of action (Savarino et al., 1993). The gene coding for EAST-1, astA, is frequently isolated from porcine ETEC strains harbouring the genes for F4 and STa toxin (Choi et al., 2001). The gene astA has also been isolated from healthy subjects, thus the ability of EAST-1 to induce diarrhea mediated by ETEC strains (Ngeleka et al., 2003) and to stimulate loss of electrolytes from intestines (Berberov et al., 2004) currently remains elusive. 


\subsubsection{STa ToXIN}

The STa toxin is coded by the gene estA located on the transposon Tn1681 which is itself carried by plasmids (So et al., 1980). STa is first synthesized as a 72 amino acid pre-polypeptide which is translocated to the periplasm via the sec machinery (Okamoto et al., 1990). This pre-polypeptide then undergoes proteolytic cleavage yielding an intermediate 53 amino acid form of the toxin which is secreted in the extracellular milieu to be cleaved again, thus, giving rise to mature STa toxin, a toxin of 18 or 19 amino acids (Rasheed et al., 1990). STa is a structural analogue to guanyline, an endogenous peptide regulating the transport of water and electrolytes across the epithelium (Giannella, 1995).

The pathogenesis mediated by STa toxin begins by the binding of the toxin to the trans-membrane guanylate cyclase type $\mathrm{C}$ receptor $(\mathrm{GC}-\mathrm{C})$ resulting in the activation of the guanylate cyclase in enterocytes. Stimulated guanylate cyclase, in turn, synthesizes cGMP from Guanosine triphosphate (GTP) resulting in the rise of cGMP levels (Vaandrager, 2002). Increases in cGMP levels lead to cGMP-dependent protein kinase II phosphorylation of CFTR causing its activation. Secretion of chloride and water by osmosis and inhibition of sodium absorption ensues leading to the occurrence of diarrhea (Sears et al., 1996, Vaandrager, 2002). 


\section{STb TOXIN}

STb toxin was isolated by Burgess et al. in 1978 from the porcine ETEC strain P16 (Burgess et al., 1978). Prior to the identification of STb, STa was the only known ST toxin associated with ETEC strains. Abnormalities observed during the purification process of the ST indicated the production of more than one ST toxin by the strain P16. Indeed, this toxin revealed itself to be insoluble in methanol, a feature which clearly distinguishes it from methanol-soluble STa toxin. The activity of this new toxin was then evaluated in ligated intestines of newborn piglets, weaned piglets, rabbits, and calves. This toxin was shown to be active in the intestines of weaned piglets and rabbits and inactive in the intestines of newborn piglets and calves, contrary to STa toxin. The differences in the activities of the ST toxins in the intestines of newborn piglets and weaned piglets further confirmed the production of a toxin other than STa by the strain P16. The discovery of this new toxin could explain the variability of ST activity in ligated rabbit intestines and in mice leading to the speculation that ETEC strains produce more than one ST toxin. As the variability observed arose from ST toxin, this new methanol-insoluble toxin was named STb enterotoxin (Burgess et al., 1978). 


\subsection{GENETICS}

The gene $e s t B$ which codes for STb toxin was first shown to be carried on a transposon by Lee et al. (1985). This transposon, which itself is carried on the P307 plasmid, is flanked by defective IS2 elements yet is capable of transposing from one plasmid to another. Transposition assays conducted by Lee et al. (1985) demonstrated that the transposon carrying the gene est $B$ uses a simple transposition mechanism to transpose from the pBR322 plasmid to the F plasmid. As the sizes of pBR322, the F plasmid, and estB gene are, respectively, $14 \mathrm{~kb}, 4 \mathrm{~kb}$, and $1 \mathrm{~kb}$, the estimated the size of the transposon carrying the gene coding for $\mathrm{STb}$ was $9 \mathrm{~kb}$ (Lee et al., 1985). The transposition of the gene $e s t B$ seems to be a mechanism by which virulence factors are disseminated from one ETEC strain to another. The gene coding for $\mathrm{STb}$ toxin from various clinical isolates appeared uniform in size, however, flanking sequences are heterogeneous suggesting that the est $B$ gene can be found on heterogeneous transposons. Indeed, the plasmids carrying the transposon coding for $\mathrm{STb}$ are also heterogeneous as they carry genes coding for STa, LT, colonization factors, and colicin (Harnett et al., 1985).

The transposon carrying the estB gene was designated $\mathrm{Tn} 4521(\mathrm{Hu}$ et al., 1987) and was further characterized in studies conducted by $\mathrm{Hu}$ et al. (1987; 1988). Terminal regions were shown to be composed of IS2 sequences in an inverted position (Hu et al., 1987). Mutations of different regions of Tn4521 
resulted in the finding that the right terminal area was required for transposition. An ORF located within the right terminal area codes for a 159 amino acid protein which was shown by frameshift mutation to be essential for transposition. This suggested that this protein could be a possible transposase for the functional transposon $\mathrm{Tn} 4521$ (Hu et al., 1988).

As STb toxin produced by ETEC strains is relatively low, the strength of the promoter controlling the expression of est $B$ gene was assessed by Spandau and Lee (1987) (Spandau et al., 1987). The promoter and the 5' coding sequence of est $B$ gene were fused to the lac $Z$ gene such that the production of $\beta$ galactosidase was under the control of the est $B$ gene promoter. The strength of the promoter controlling estB gene expression was compared to the strength of the ompF and lac operons fused to the lacZ gene. The mRNA transcript of each promoter was analyzed by Northern blot and in vitro transcription. Low levels of the mRNA transcript of the lac $Z$ gene were observed under the control of the promoter of the estB gene indicating a weak promoter. Quantification of the $\beta$-galactosidase protein produced under the control of the estB gene promoter yielded low protein levels further confirming a weak promoter. 


\subsection{SYNTHESIS}

Nucleotide sequencing of the estB gene revealed STb toxin is synthesized as a 71 amino acid peptide. The presence of a peptide-like sequence in the amino terminal region suggests $\mathrm{STb}$ is synthesized as a pre-toxin and is subsequently transported across the bacterial membrane (Lee et al., 1983) (Figure 2). Indeed, amino acid sequencing of STb produced by ETEC cultures revealed a protein of 48 amino acids (Kupersztoch et al., 1990) while SDS-PAGE experiments determined the molecular mass of mature $\mathrm{STb}$ toxin to be $5.2 \mathrm{kDa}$ (Lawrence et al., 1990). The first 23 amino acids present in the pre-toxin were not observed in the extracellular form of STb suggesting that proteolytic cleavage plays a role in the maturation of STb (Kupersztoch et al., 1990). Cellular fraction experiments demonstrated that the same form of STb, confirmed by amino acid sequencing, is present in the periplasm and extracellularly. According to the authors, this suggested proteolytic cleavage yielding mature $\mathrm{STb}$ occurs in the periplasm. As the $\sec A$ gene is implicated in the conversion of periplasmic and outer membrane proteins from their precursor into the mature forms, the implication of $\sec A$ in the conversion of $\mathrm{STb}$ pre-toxin into mature $\mathrm{STb}$ was investigated. Bacteria mutated in the $\sec A$ gene did not express mature extracellular STb indicating that the conversion of $\mathrm{STb}$ to its mature form is dependent on $\sec A$ gene expression (Kupersztoch et al., 1990). 


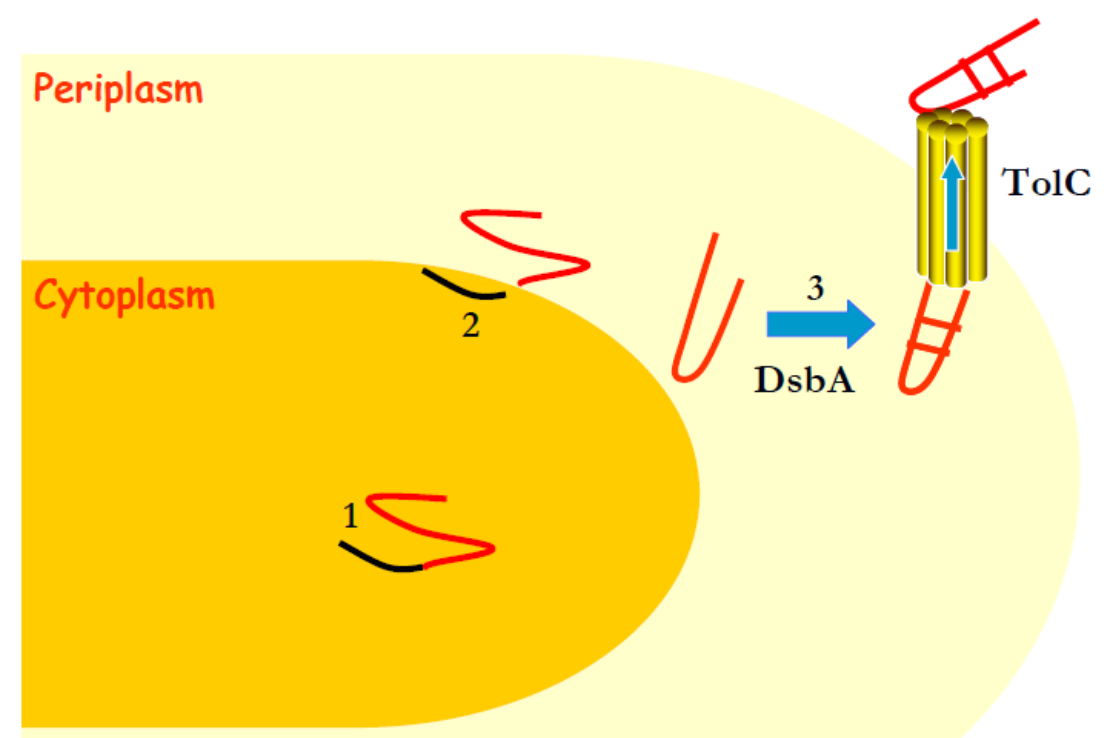

Figure 2: Synthesis of STb toxin. 1. STb is first synthesized in the cytoplasm as a pre-polypeptide. 2. Proteolytic cleavage occurs in the periplasm giving rise to mature $\mathrm{STb}$. 3. DsbA assures the formation of disulfide bonds in the periplasm. Mature $\mathrm{STb}$ is then secreted into the extracellular medium via TolC. (Taillon, 2010).

Proteolytic cleavage is followed by the formation of disulfide bonds in the periplasm (Dreyfus et al., 1992). Indeed, the presence of 4 cysteine residues observed by Burgess et al. (1978) pointed to the possibility of disulfide bonds being formed between these residues. Furthermore, the observation that treatment of STb toxin with a reducing agent caused a decrease in toxicity supported the hypothesis that disulfide bonds may be present in mature $\mathrm{STb}$ (Dreyfus et al., 1992). STb peptides which became unlinked following DTT treatment were sequenced in order to determine the cysteine residues implicated in the formation of the disulfide bonds. The cysteine residues at the 
10-48 and 21-36 positions of mature STb formed disulfide bonds with each other. Oligonucleotide-directed mutagenesis eliminating one or both disulfide bonds resulted in the inability of STb to translocate from the periplasm to the extracellular environment and reduce the toxic activity of STb. Taken together, these findings indicate both of the disulfide bonds are essential for the translocation of $\mathrm{STb}$ from the periplasm to the extracellular environment and are necessary for STb to retain its toxic activity (Dreyfus et al., 1992). A subsequent study confirmed the role of disulfide bonds in STb toxicity (Arriaga et al., 1995).

The implication of Disulfide-bond A oxidoreductase (DsbA) in the formation of disulfide bonds of STb was verified by Okamoto et al. (1995). Cellular fraction of DsbA mutants revealed STb is not present in either the periplasm or in culture supernatants. This suggested that DsbA is implicated in the maturation of $\mathrm{STb}$ toxin. Indeed, complementation of $d s b A$ - strains with wildtype strains resulted in the detection of STb in the periplasm and in culture supernatant. The role of DsbA in the formation of disulfide bonds in STb toxin was determined by substituting DsbA with Disulfide-bond C oxidoreductase (DsbC), another protein implicated in disulfide bond formation in E. coli. Substitution experiments revealed a lack of disulfide bonds in STb indicating that DsbA, but not DsbC, is involved in disulfide formation in STb. 
The implication of Outer membrane channel protein (TolC) and DsbA in the secretion of mature STb from the periplasm to the extracellular environment has also been demonstrated (Foreman et al., 1995). Bacteria harboring TolC mutants were unable to secrete $\mathrm{STb}$ into the extracellular environment. This indicates that TolC could act as channel permitting the passage of STb from the periplasm into the extracellular medium. Although the protein DsbA is implicated in the formation of disulfide bonds between cysteine residues (Okamoto et al., 1995), Foreman et al. (1995) observed that STb was not detected in the extracellular environment of DsbA mutants. Indeed, the absence of disulfide bonds renders STb susceptible to proteolytic cleavage and, thus, results in the absence of STb in the extracellular medium.

\subsection{BiochemicAL STRUCTURE}

Nuclear Magnetic Resonance (NMR) studies revealed that mature STb toxin is composed of two antiparallel alpha-helices separated by a glycine-rich loop (Figure 3) (Sukumar et al., 1995). The first $\alpha$-helix, located between the amino acid residues 10 to 22 , is hydrophilic, explaining the exposure of the lateral chains of amino acids Asp $8, \mathrm{His}_{12}, \mathrm{Gln}_{15}, \mathrm{Lys}_{18}, \mathrm{Glu}_{19}$, $\mathrm{Lys}_{22}$, and $\mathrm{Lys}_{23}$ to the solvent. The second $\alpha$-helix ranges from amino acid residues 38 to 44 and is hydrophobic. The glycine-rich loop is located between residues 21 and 36 and contains a cluster of hydrophobic residues. The authors of this study also conducted Circular Dichroism (CD) experiments revealing loss of the 
disulfide bridges results in loss of STb structure, which was associated with a loss of function (Sukumar et al., 1995), findings observed by Dreyfus et al. (1992) and Arriaga et al. (1995).

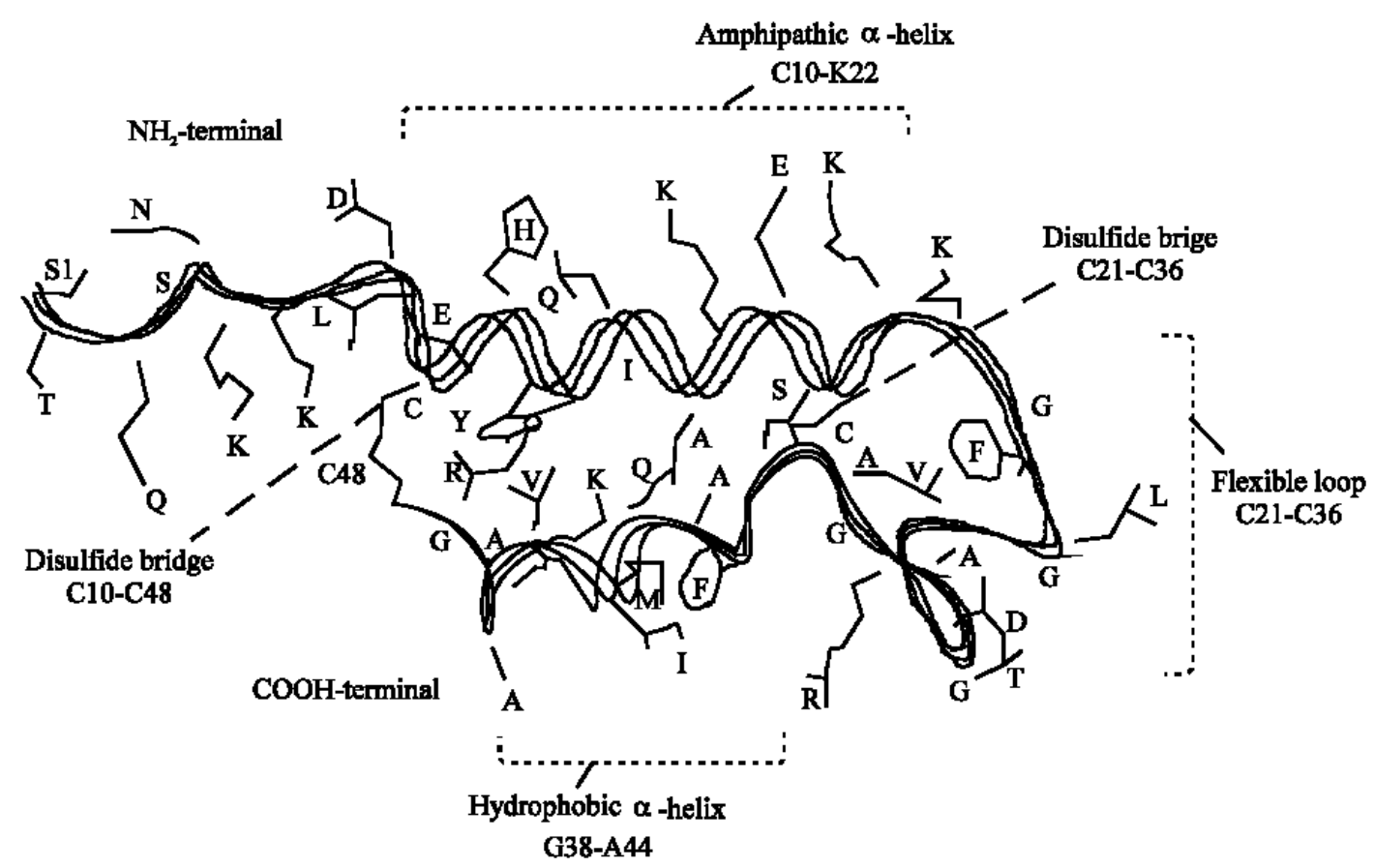

Figure 3: Tertiary structure of STb toxin. Mature STb is composed of an amphipathic $\alpha$-helix, a glycine-rich flexible loop, a hydrophobic $\alpha$-helix, and two disulfide bonds. (Sukumar et al., 1995)

The $\alpha$-helix in the carboxy-terminal region has been shown to be implicated in the formation of oligomers by STb toxin. Site-directed mutagenesis of residues located in this $\alpha$-helix identified the hydrophobic amino acids $\mathrm{Phe}_{37}$, $\mathrm{Ile}_{41}$, and $\mathrm{Met}_{42}$ as being indispensable to the formation hexamers and heptamers. The effect of temperature on the formation of oligomers was also evaluated and revealed that temperature has no effect on oligomerization of 
STb. Treatment of STb with $\beta$-mercaptoethanol, a reducing agent which prevents the formation of disulfide bonds, interferes with the formation of oligomers indicating proper structure is required for the formation of oligomers. The influence of the presence or absence of sulfatide, the toxin's receptor, was also investigated and demonstrated that oligomerization occurs independently of the presence of sulfatide (Labrie et al., 2001b).

\subsection{RECEPTOR OF STb TOXIN}

The chemical nature of the receptor of STb was first determined by Rousset et al. (1998a) who observed the attachment of STb to microvilli of frozen porcine tissue cuts. Attachment assays conducted by Rousset et al. (1998a) revealed that attachment of STb to microvilli occurs rapidly with saturation occurring after 10 minutes. The optimum $\mathrm{pH}$ of this attachment has been reported to be 5.8 while temperature has no effect on attachment. Attachment of STb to all tissues tested (jejunum, duodenum, caecum, liver, spleen, and kidney) was reported. These observations suggest that the molecule acting as a potential receptor for STb is a surface molecule ubiquitously present on these tissues. In order to determine the chemical nature of STb's receptor, tissues were subjected to enzymatic and chemical treatments prior to attachment assays conducted with $\mathrm{STb}$, identifying a glycosphingolipid as a potential receptor (Rousset et al., 1998a). 
In a subsequent study by Rousset et al. (1998b), attachment of STb to various commercial glycolipids was tested revealing strong attachments to acidic glycosphingolipids and to certain gangliosides. Amongst the glycolipids tested, attachment of STb to sulfatide was the strongest and occurred in a dosedependent and saturable manner. A lipid extracted from jejunum brush border epithelial cells was analyzed by thin layer chromatography revealing the presence of a molecule having the same migration distance as commercial sulfatide, an acidic glycosphingolipid abundantly present at the surface of intestinal epithelial cells. In addition, this molecule was also recognized by an anti-sulfatide antibody. These results permitted the identification of sulfatide as a functional receptor for STb toxin (Rousset et al., 1998b). Indeed, pretreatment of ligated rat intestine segments with either laminine, known to interact specifically with sulfatide, or sulfatase resulted in a decrease of STb activity supporting the finding that sulfatide could be the receptor of $\mathrm{STb}$ (Rousset et al., 1999). Mass spectrometry would later confirm sulfatide as the receptor of STb toxin (Beausoleil et al., 2002b).

The affinity and physical characteristics of the binding of STb to sulfatide was determined by microplate binding assays. These experiments demonstrated that STb binds to sulfatide with a high specifity in a dose-dependent and saturable manner (Beausoleil et al., 2001). However, the affinity of this interaction was described as weak as demonstrated by the kd value of $2-6+/-$ $1.5 \mu \mathrm{M}$ and was partially inhibited by elevated concentrations of charged 
carbohydrates. The kd value obtained by the authors is in accordance with the value obtained by Chao and Dreyfus (1997) who studied the interaction of STb with intestinal epithelial cells such as T84 and HT29 cells. The affinity of STb to sulfatide would be re-evaluated with the use of SPR (Surface Plasmon Resonance) technology obtaining a $\mathrm{kd}$ value of $2.4+/-0.6 \mathrm{nM}$ indicating a higher affinity of STb to sulfatide (Goncalves et al., 2008) than that reported by Beausoleil and Dubreuil (2001). The kd value obtained by Goncalves et al. (2008) was in accordance with values obtained for other toxins possessing glycolipid molecules as functional receptors. Carrageenan was shown to inhibit the interaction between STb and sulfatide as well as permeabilization of cell membranes caused by STb (Goncalves et al., 2008). Thus, carrageenan could represent a molecule that could be used as a prophylactic agent to protect piglets against STb during the post-weaning period.

\subsection{INTERNALIZATION}

Internalization of STb toxin was first reported by Chao and Dreyfus (1997) who had observed that STb integrates within the membrane of cells following its attachment to epithelial cells. The internalization of STb occurred independently of temperature, cytoskeleton rearrangements, energy, and hypertonic conditions. These results suggested that the processes of clathrindependent and -independent, caveolae internalization or micropinocytosis were not implicated in STb uptake. The authors of this study emitted the 
hypothesis that the formation of a stable complex with lipids rather than internalization by a ligand could be the mode of STb internalization. As well, the authors suggested that the toxin associated to the membrane could directly penetrate the membrane to interact with regulatory proteins such as $\mathrm{G}$ proteins (Chao et al., 1997).

The fate of STb following uptake was studied by Labrie et al. (2002) in vivo in rat intestinal epithelial cells using an anti-STb gold labeled assay and transmission electron microscopy revealing that $\mathrm{STb}$ does not seem to target a particular organelle as gold particles were observed dispersed throughout cells. Internalization of wild-type and the mutant I41E-M42R characterized by decreased hydrophobicity were compared and revealed diminished uptake of the mutant indicating these amino acids are essential to proper internalization of STb (Labrie et al., 2002). Indeed, site-specific mutagenesis of the residues $\mathrm{Phe}_{37}, \mathrm{Ile}_{41}$ and Met ${ }_{42}$ demonstrated they are necessary to the binding of STb to its receptor as these mutations resulted in reduced binding (Labrie et al., 2001a), thus supporting the decrease of the uptake of these mutants observed by Labrie et al. (2002). The toxicity of these mutants was evaluated in the rat loop assay revealing decreased toxicity compared to the wildtype. The contribution of the residues $\mathrm{Gly}_{22}, \mathrm{Gly}_{23}$, and $\mathrm{Arg}_{29}$ of the flexible loop was evaluated and also exhibited decreased binding and toxicity of STb toxin. Overall, these data suggested that hydrophobic and electrostatic interactions are important for STb binding and toxicity (Labrie et al., 2001a). 


\subsection{Mode OF ACTION}

A distinguishing characteristic of the colibacillosis mediated by STb in animals is the lack of adenylate cyclase and guanylate cyclase activation as observed in diarrhea induced by LT and STa toxins (Hitotsubashi et al., 1992, Peterson et al., 1995). The binding of STb toxin is followed by uptake of the toxin resulting in the stimulation of a pertussis-sensitive $\mathrm{G}$ protein and in an increase of intracellular calcium levels. Augmented calcium levels are the result of an influx of calcium ions inside cells as demonstrated by Dreyfus et al. (1993). Pretreatment of cells with inhibitors of calcium channels following $\mathrm{STb}$ treatment revealed a lack of increase of intracellular calcium levels indicating increases of calcium levels are the result of an influx from the extracellular medium. Calcium influx leads to the activation of a calmodulindependent kinase II protein as the activation was not observed in cells pretreated with calcium channel inhibitors (Fujii et al., 1997, Dreyfus et al., 1993). Calmodulin-dependent kinase II protein stimulates the opening of an ionic channel as well as the activation of a kinase $\mathrm{C}$ protein and of CFTR (Dreyfus et al., 1993).

Augmented calcium levels also regulate the activities of the phospholipases $\mathrm{A}_{2}$ and $\mathrm{C}$ and induce the release of arachidonic acid from membrane phospholipids which in turn leads to the production of prostaglandin $E_{2}$ and serotonin (5-HT) (Peterson et al., 1995, Fujii et al., 1995). Release of these 
secretagogues occurs in a dose-dependent manner in response to increasing quantities of $\mathrm{STb}$ in the intestinal lumen. Indeed, treatment of rats with ketanserin, an antagonist of serotonin receptors, results in decreased intestinal secretion by STb implying a role of serotonin in the mode of action of $\mathrm{STb}$ (Harville et al., 1995). Moreover, Fujii et al. (1995) demonstrated serotonin release and fluid accumulation is proportional to the quantity of STb used to treat cells. These results are in accordance with the observations made by Harville and Dreyfus (1995).

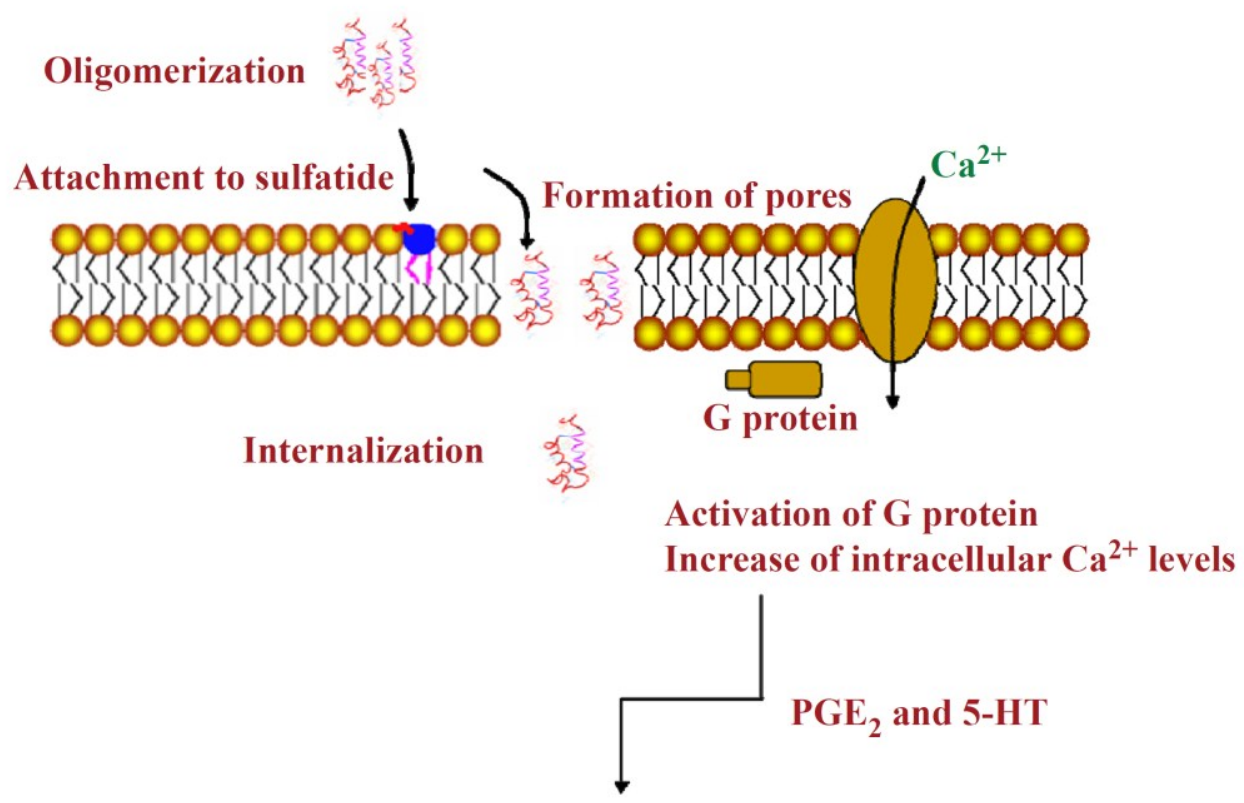

Secretion of electrolytes and water

Figure 4: Proposed mode of action of STb toxin. Oligomerized STb toxin binds to its receptor, sulfatide (blue), and is internalized presumably through the formation of pores. Pores also permit an influx of calcium to occur resulting in the activation of a $G$ protein and in an increase of intracellular 
calcium levels. Augmented calcium levels stimulate prostaglandin $E_{2}$ and serotonin $(5-\mathrm{HT})$ which in turn are responsible for stimulating the secretion of electrolytes and water. (Taillon, 2010).

Stimulation of secretagogues is followed by the secretion of electrolytes, which include $\mathrm{Na}^{+}, \mathrm{Cl}^{-}$, and $\mathrm{HCO}^{-}$, and water in the intestinal lumen (Figure 4). Fluid accumulation caused by STb was evaluated in mouse intestinal loop assays by Hitotsubashi et al. (1992). The authors observed fluid accumulation occurs as rapidly as 30 minutes following STb treatment and with maximum accumulation occurring at 3 hours (Hitotsubashi et al., 1992). The diarrhea caused by STb was reported to be accompanied by histological damages characterized by shortening and atrophy of the villi as well as replacement of columnar epithelial cells with cuboidal or squamous cells (Whipp et al., 1986, Whipp et al., 1987). The shortening and atrophy of the villi were subsequently confirmed using morphometric techniques (Rose et al., 1987). Swine, lamb, and rabbit intestines exposed to STb-positive filtrates were measured and revealed reduction of villous epithelial surface area and mucosal volume in swine and lamb intestines. These data supports the hypothesis that a species ability to secrete in response to STb treatment is required for histological damages to occur (Whipp et al., 1986). The damages observed by Whipp et al. (1986) and Rose et al. (1987) have been attributed to loss of absorptive capacity as well as to the induction of net secretion caused by STb.

The ability to form pores by STb in swine brush border membrane vesicles was evaluated by Goncalves et al. (2007). Brush border membrane vesicles 
were treated with pure toxin followed by a treatment to valinomcyin, a potent membrane potential generator, which in turn results in an efflux of potassium ions. The membrane potential sensitive probe revealed a decrease in the membrane potential of the vesicles treated with STb and valinomycin indicating STb permeabilizes the membrane to ions other than potassium. The lack of change in membrane potential of vesicles treated with STb but not valinomycin suggests the permeability of STb is nonspecific. The ability of $\mathrm{STb}$ to form pores was also assessed in this study. Vesicles treated with $\mathrm{STb}$ and valinomycin were placed in an isotonic solution of N-methyl-D-glucamine hydrochloride (NMDGCl). Fluorescence levels increased before leveling off with increasing quantities of STb toxin indicating pore formation depends on the interaction of STb with its receptor and occurs in a dose-dependent and saturable manner. The pores formed by $\mathrm{STb}$ could be partially responsible for the loss of electrolytes and water observed during diarrhea mediated by STb (Goncalves et al., 2007).

A subsequent study by Goncalves et al. (2009) evaluating the internalization mechanism of $\mathrm{STb}$ revealed $\mathrm{STb}$ induces apoptotic-like morphology of cultured cells characterized by cell shrinkage, membrane blebbing, granular cytoplasm, and enlarged nuclei. Cells labeled with PI revealed colocalization of FITC-labeled STb with mitochondrion which was observed by confocal microscopy after 6 hours and became more pronounced after 12 hours. Cells treated with STb demonstrated dose-dependent changes in mitochondrial 
membrane potential, over time, as measured with the fluorescent probe JC-1 and flow cytometry. Though not proven by Goncalves et al., (2009) the results obtained by the authors suggest STb could possibly possess the ability to kill eukaryotic cells.

\subsection{Immunogenic Potential}

The capacity of STb to induce neutralizing antibodies was verified by immunizing rabbits with purified toxin isolated from ETEC porcine strains. ELISA assay was used to determine the level of antibodies present in the serum of immunized rabbits revealing low levels of antibodies. A poor level of antibody production was also observed following the administration of booster shots suggesting that STb is a poor immunogen (Dubreuil et al., 1991). The low yield in antibodies was attributed to the small size of the toxin. Subsequent studies examined the production of neutralizing antibodies against $\mathrm{STb}$ in rabbits and mice immunized with the fusion proteins ompF-STb- $\beta$ galacosidase (Lawrence et al., 1990) and STb-KLH (Urban et al., 1990), respectively, in an attempt to circumvent the small size of $\mathrm{STb}$ toxin. Immunization of animals with fusion proteins containing STb increased the production of antibodies against $\mathrm{STb}$, measured by ELISA, in both of these studies. 
Similarly, a subsequent study also revealed an augmentation in the production of anti-STb neutralizing antibodies in rabbits immunized with the fusion protein maltose binding protein-heat stable toxin $\mathrm{b}$ (MBP-STb) (Dubreuil et al., 1996). The authors also evaluated the production of neutralizing antibodies following the immunization of rabbits with a fusion protein comprised of MBP and truncated STb revealing a lack of production of antibodies. This suggested that the conformation and each amino acid influenced the immunogenic properties of STb toxin. However, neutralizing antibodies directed against STb are incapable of neutralizing STa or CT toxins indicating STb possesses distinctive immunogenic properties not shared with either STa or CT and pointing to the possibility of STb possessing a differing mode of action than STa or CT (Hitotsubashi et al., 1992).

\section{APOPTOSIS}

The term apoptosis was first coined by Kerr, Wyllie, and Currie in 1972 to describe a form of programmed cellular death distinctive from necrosis (Kerr et al., 1972). The term apoptosis originates from Greek ("falling off" as leaves fall from trees) and is used to describe a controlled physiological process of removing individual components of an organism without damage or destruction of the organism. Kerr and his colleagues observed that apoptosis of embryonic tissues was consistently accompanied by structural changes such as membrane blebbing, cell shrinkage, chromatin condensation, and nuclear 
fragmentation which were visualized by electron microscopy. The structural changes of apoptosis occur in two phases: the first consisting of nuclear and cytoplasmic condensation followed by the breaking up of the cell into membrane-bound vesicles (Kerr, 1971), and the second consisting of the elimination of these apoptotic bodies by either phagocytosis or degradation by other cells (Kerr, 1972).

The formation of apoptotic bodies is characterized by nuclei and cytoplasmic condensation, nuclear fragmentation, and detachment of cells from tissues (Kerr, 1971). Apoptotic bodies are condensed cell fragments harboring condensed chromatin and tightly-packed organelles (Kerr, 1972). The exact composition of apoptotic bodies will vary and depend on the cellular constituents present at the time of the formation of these bodies. The varied composition of apoptotic bodies also influences their size: small apoptotic bodies are composed of nuclear chromatin whereas large ones are composed of cytoplasmic components. The degree of condensation of apoptotic bodies is thought to be the result of water exclusion which also influences their size (Kerr et al., 1972).

The presence of apoptotic bodies in intact cells suggested elimination of these bodies by phagocytosis. Kerr et al. (1972) believed these bodies were being engulfed by cells due to changes in the properties of their surface membranes. Ingested apoptotic bodies then undergo a process within phagosomes that is 
similar to in vitro autolysis of whole cells (Trump et al., 1965). The membranes of the apoptotic bodies inside phagosomes as well as the membranes of the organelles located within these apoptotic bodies are degraded, ribosomes become swollen and undistinguishable, and cessation of metabolic activities of the apoptotic bodies occurs. Lysosomal enzymes are then acquired as a result of the fusion of the phagosomes with lysosomes and contribute to the degradation of apoptotic bodies. The process of phagocytosis and subsequent elimination of apoptotic bodies usually occurs within a 24hour timeframe (Kerr, 1971).

According to Kerr et al., (1972) the appearance of apoptotic bodies in healthy tissues indicates apoptosis occurs in healthy tissues as a result of normal cell turnover. Indeed, apoptosis is considered as a form of controlled cell death occurring in healthy adult mammalian tissues contributing to the maintenance of the cell population within these tissues. The occurrence of apoptosis in embryonic tissues at specific time points during development supported the notion of apoptosis being a form of controlled death responsible for the maintenance of cellular populations (Saunders, 1966). Kerr et al. (1972) had observed that the susceptibility of embryonic cells to apoptosis varies depending on the developmental stage in which they are. The developmental timing of apoptosis and the consistent accompanying morphological changes highlighted the possibility of apoptosis being genetically regulated (Kerr et al., 1972). 


\subsection{Genetic Regulation of Apoptosis}

The genetic regulation of apoptosis was confirmed by studies conducted by the team led by Horvitz using Caenorhabditis elegans (Yuan et al., 1993, Yuan et al., 1992, Conradt et al., 1998, Hengartner et al., 1992, Hengartner et al., 1994) and will be discussed in greater detail below. The nematode C. elegans was chosen by Horvitz and his team to study cell death due to its small size, cellular simplicity, easy handling, and rapid generation time (Wood et al., 1988). Moreover, as C. elegans is transparent, death of individual cells is relatively easy to observe in the living organism. Horvitz and his team created mutants by transposon insertion in order to identify genes implicated in the process of apoptosis. Many of the genes subsequently identified were determined to possess a human counterpart and according to Horvitz and his team, suggested molecular mechanisms regulating cell death are conserved in nematodes and mammals (Figure 5). 


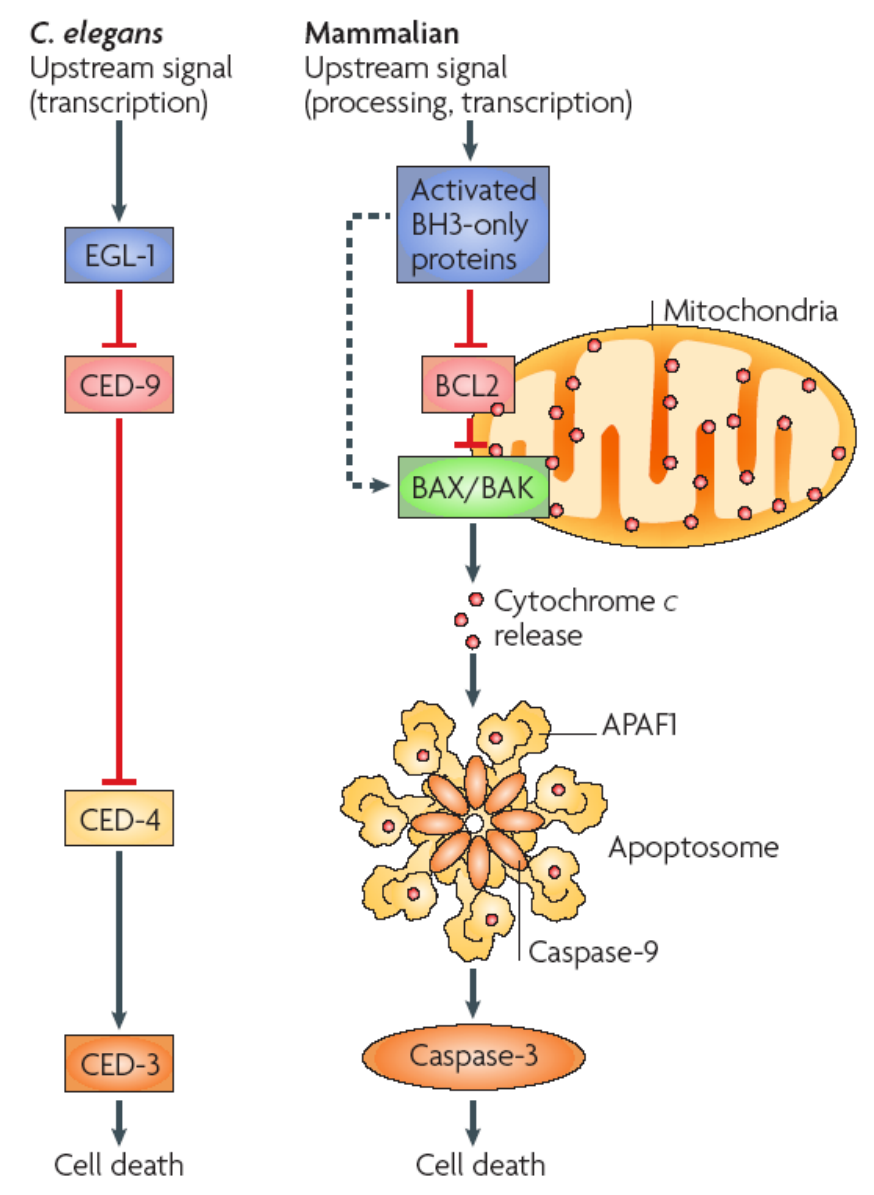

Figure 5: Comparison of the cellular death pathway in C. elegans and in mammals. Each protein implicated in cell death in C. elegans possesses a human homologue. (Degterev et al., 2008)

Studies conducted on ced-3 (Yuan et al., 1993), ced-4 (Yuan et al., 1992), ced9 (Hengartner et al., 1992, Hengartner et al., 1994), and egl-1 (Conradt et al., 1998) genes resulted in the inhibition of apoptosis, suggesting all four genes are essential to programmed cell death and that apoptosis is an active process. The Cell Death Protein 3 (CED-3) was shown to be similar to the human cysteine protease Interleukin-1 $\beta$ Converting Enzyme (ICE), suggesting it could be a caspase-like protein. Indeed, both CED-3 and ICE are generated as 
pro-proteins requiring proteolytic cleavage to be activated. CED-3 will then modulate cell death by activating downstream proteins responsible for cell death and by inactivating proteins which protect cells from death, similarly to caspase-3 in mammals (Yuan et al., 1993). Cleavage of CED-3 is mediated by Cell Death Protein 4 (CED-4), a protein bearing similar amino acid sequence to Apoptosis Protease Activating Factor-1 (APAF-1) (Yuan et al., 1992). The protein Egg-Laying Protein 1 (EGL-1) contains a B-cell lymphoma 2 homology domain 3-like domain (BH3) which allows it to interact with the Bcell lymphoma 2-like protein (BCL-2) Cell Death Protein 9 (CED-9) thereby suppressing the inhibition of apoptosis exerted by CED-9 (Conradt et al., 1998).

Decreased or elimination of CED-9 resulted in cells undergoing apoptosis instead of surviving. Conversely, over-expression of CED-9 causes cell survival (Hengartner et al., 1992). Amino acid sequencing of CED-9 revealed that it is similar to the human proto-oncogene BCL-2, a protein which suppresses cell death. Expression of cloned human BCL-2 in C. elegans caused cell survival in cells destined to die as well as in ced-9 deficient cells. These results suggest CED-9 and BCL-2 are functional homologues and support the idea of the conservation of molecular mechanisms regulating cell death in both nematodes and mammals (Hengartner et al., 1994). 


\subsection{BCL-2 FAmily Proteins}

B cell lymphoma 2 (BCL-2) family proteins have been shown to play essential roles in the regulation of apoptosis (Youle et al., 2008). The first protein discovered in this family was BCL-2 which was defined as the key oncogene in follicular lymphomas (Tsujimoto et al., 1985). Non-cancerous cells introduced with the BCL-2 protein demonstrated an increased capacity to survive in the absence of growth factors and showed a suppression of the expression of morphological features associated with apoptosis such as membrane blebbing, nuclear condensation, and DNA cleavage. These findings suggested that BCL-2 can both promote proliferation and actively block cell death in cancer cells which, unlike other known oncogenes at the time, were strictly attributed to the proliferation of cancer cells. Hence, BCL-2 was classed as an anti-apoptotic protein (Vaux et al., 1988, McDonnell et al., 1989).

Amino acid sequencing of BCL-2 family proteins revealed that these are structurally diverse yet share up to four BCL-2 homology domain (BH domains) and one transmembrane domain (TM) (Figure 6). Anti-apoptotic members possess all four $\mathrm{BH}$ domains while pro-apoptotic members possess up to three BH domains. Pro-apoptotic BCL-2 family proteins can be further subdivided into two categories: the first consisting of proteins harboring the $\mathrm{BH} 3$ domain in combination with $\mathrm{BH} 1$ and $\mathrm{BH} 2$ while the second class of proteins carry only the $\mathrm{BH} 3$ domain. The proteins carrying $\mathrm{BH} 3$ and another 
$\mathrm{BH}$ domain are known as BH1-3 proteins whereas proteins carrying solely the $\mathrm{BH} 3$ domain are known as BH3-only proteins (Degterev et al., 2008, Lomonosova et al., 2008).

1. Anti-apoptotic proteins, BH1-4-BCL-2, BCL-xL, MCL-1, A1, BCL-w

\begin{tabular}{|l|l|l|l|l|l|l|l|l|}
\hline BH4 & BH3 & BH1 & & BH2 & TM & BCL-2 \\
\hline
\end{tabular}

2. Pro-apoptotic proteins, BH1-3-BAX, BAK, BOK

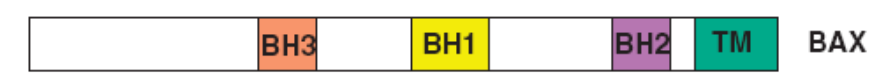

3. Pro-apoptotic proteins, BH3-only -BIK, BID, BIM, BAD,

PUMA, NOXA, HRK etc

\begin{tabular}{|l|l|l|}
\hline BH3 & TM & BIK \\
\hline
\end{tabular}

Figure 6: BCL-2 family proteins. Anti-apoptotic proteins are characterized by the presence of all four $\mathrm{BH}$ domains. Pro-apoptotic members harbor domains $\mathrm{BH} 1-\mathrm{BH} 3$ or only the $\mathrm{BH} 3$ domain. The $\mathrm{BH} 3$ domain is the core domain of all BCL-2 family proteins. (Lomonosova et al., 2008)

\subsubsection{BH3 DOMAIN}

The $\mathrm{BH} 3$ domain is the only domain present in all BCL-2 family proteins, and thus, considered the core-defining domain of this family of protein (Figure 6) (Youle et al., 2008). Consequently, this domain has been more extensively studied than the other domains associated with the BCL-2 family proteins. The confirmation that the $\mathrm{BH} 3$ domain is implicated in apoptosis comes from studies conducted on Bcl-2-interacting killer (BIK) and BCL-2 homologous antagonist/killer (BAK). Mutations of this domain in BAK and BIK resulted 
in the inability of these proteins to initiate apoptosis. Moreover, neither mutated BIK nor BAK is able to interact with the anti-apoptotic proteins of the BCL-2 family proteins to neutralize their anti-apoptotic effect exerted by BH4 suggesting the $\mathrm{BH} 3$ domain played a role in the induction of apoptosis (Boyd et al., 1995, Zha et al., 1996). The requirement of the BH3 domain to interact with anti-apoptotic BCL-2 family members in order for apoptosis to occur was subsequently studied in the yeast using the two-hybrid system. Mutations of the $\mathrm{BH} 3$ resulted in the absence of interactions of $\mathrm{BH} 3$-only proteins with antiapoptotic BCL-2 proteins and subsequent apoptosis further supporting a role for the BH3 domain in the induction of apoptosis (Sattler et al., 1997).

The in vivo contribution of the $\mathrm{BH} 3$ domain to apoptosis was confirmed in studies conducted on the C. elegans protein EGL-1, discussed above, and in knock-out mouse models for the $\mathrm{BH} 3$-only proteins $\mathrm{BH} 3$ interacting-domain death agonist (BID) and BCL-2-like protein 11 (BIM). Hepatocytes of knockout BID mice were shown to be resistant to apoptosis (Yin et al., 1999) as were lymphocytes of BIM-deficient mice (Bouillet et al., 1999). According to Bouillet and Strasser (2002) (Bouillet et al., 2002), this further supported the role of $\mathrm{BH} 3$ being essential during apoptosis and demonstrated the cell-type specific implication of $\mathrm{BH} 3$-only proteins. 


\subsection{CASPASES}

Caspases are a family of cysteine-aspartate proteases which play an integral role in apoptosis. The elegant study conducted by Thornberry and her team in 1992 (Thornberry et al., 1992) would allow the authors to identify ICE, an enzyme responsible for the cleavage of the membrane-bound precursor of interleukin-1 $\beta$ into its active cytokine form (Kostura et al., 1989, Black et al., 1989), as the first caspase. Thornberry et al. (1992) purified ICE using RPHPLC and subjected peak fractions to SDS-PAGE revealing one protein of 22 $\mathrm{kDa}$ and one of $10 \mathrm{kDa}$. Mass spectral analysis determined the actual molecular masses of these proteins to be 19,866 and 10,248 Da which were designated p20 and p10, respectively. Affinity chromatography purification of ICE revealed the presence of p20 and p10 in an equimolar ratio suggesting both subunits are required for the catalytic activity of ICE (Thornberry et al., 1992).

As cleavage by ICE occurred at $\mathrm{Asp}_{116}-\mathrm{Ala}_{117}$ to yield mature IL-1 $\beta$ and at $\mathrm{Asp}_{27}-\mathrm{Gly}_{28}$ to produce a $28 \mathrm{kDa}$ protein, it seemed that the preferred cleavage site of ICE begins with an aspartic acid residue (Kostura et al., 1989, Black et al., 1989). Indeed, any substitution of the aspartic acid residue in the precursor of IL-1 $\beta$ results in a sharp reduction in the catalysis rate of ICE (Howard et al., 1991). Peptides spanning the cleavage site of the precursor of IL-1 $\beta$ were used to demonstrate ICE's minimum recognition sequence revealing Ac-Tyr- 
Val-Ala-Asp- $\mathrm{NH}-\mathrm{CH}_{3}$ (Ac: acetyl) to be this sequence. These findings suggested the requirement of at least four amino acids to the left of the cleavage site with aspartic acid being the last residue followed by the presence of at least one amino acid after the aspartic acid residue.

Amino acid sequencing revealed ICE is not homologous to any other known cellular cysteine proteases. The inhibition of ICE by diazomethylketones and iodoacetate (Rich, 1986), as well as peptide aldehydes (Wolfenden, 1969), potent inhibitors of cysteine proteases, was verified. In the presence of each these inhibitors, ICE was unable to cleave the sequence identified in the current study. The inhibition of ICE by cysteine protease inhibitors coupled with the catalytic mechanism of ICE allowed Thornberry et al. (1992) to definitely class ICE as a cysteine protease in spite of ICE not being homologous to other cysteine proteases known at the time. As cysteine proteases possess the common characteristic of cleaving substrates after specific aspartate residues, they were named caspases (cysteine-aspartate protease) (Alnemri et al., 1996). ICE, being the first identified caspase, was therefore renamed caspase-1.

Subsequently identified caspases were either classed as initiator or effectors caspases based on the substrate they cleave. Initiator caspases-8 and -9 demonstrate a preference for the substrate LExD, with $\mathrm{x}$ being a $\mathrm{T}$ or $\mathrm{H}$ residue recognized by caspases- 8 or -9 , respectively. These types of caspases are 
responsible for the activation of effector caspases such as caspases-3 and -7 which cleave the substrate DEVD (Thornberry et al., 1997). Both initiator and effector caspases are composed of a prodomain in the amino terminal region and the two catalytic units. The size of the prodomain, however, will vary according to the type of caspase: initiator caspases possess a long prodomain while effector caspases possess a short prodomain. The long prodomain of initiator caspases contains the Caspase Activation and Recruitment Domain (CARD), the domain which is responsible for the activation of the initiator caspase and the recruitment of adapter molecules (Fink et al., 2005).

The role of caspases in apoptosis was confirmed by studies using knock-out mice for different caspases. Caspase- 8 deficient mice result in embryonic lethality and developmental abnormalities in cardiac tissues characterized by thin ventricular myocardium. Knock-out mice for caspase- 8 also demonstrate hyperaemia in the abdominal cavity and blood vessels coupled with pronounced erythrocytosis in the liver (Varfolomeev et al., 1998). Mice which do not express either caspase-9 or -3 demonstrate abnormal development of the central nervous system resulting from a lack of apoptosis which is characterized by ectopic cell masses, defects in neural tube closure, and protrusion of cranial brain tissue (Kuida et al., 1996, Kuida et al., 1998). Caspase-3 remains inactivated in caspase-9 deficient mice (Kuida et al., 1998). Taken together, these results clearly demonstrate the implication of caspases in apoptosis in vivo. 


\subsection{EXTRINSIC APOPTOSIS}

Extrinsic apoptosis is triggered following the interaction of ligands such as Tumour Necrosis Factor Ligands (TNFL) or Fas Ligand (FasL) with their respective transmembrane Tumour Necrosis Factor Receptors (TNFR) or Fas Receptor (FasR) (Figure 7). TNFR are composed of cysteine-rich extracellular domains and a cytoplasmic death domain that is responsible for the transmission of signals from the cell surface to signaling pathways (Duprez et al., 2009). The interaction between a ligand and its TNFR results in the recruitment of cytoplasmic adaptor proteins TNF Receptor-Associated Death Domain (TRADD) and Fas Associated Death Domain (FADD) to the death domain of the receptor. This is followed by the recruitment of procaspase- 8 to FADD via CARD of procaspase-8 to form the Death-Inducing Signaling Complex (DISC) (Elmore, 2007). Procaspase-8 is then cleaved resulting in the generation of caspase-8, the initiator caspase of the extrinsic pathway, which is responsible for the activation of downstream targets procaspase-3 and BID. Caspase-3 will then activate caspases- 6 and -7, DNA Fragmentation Factor (DFF), and inactivate Poly [ADP-ribose] polymerase 1 (PARP-1). Caspase-8 cleaves BID to yield truncated BID (tBID), a BH3-only protein capable of activating BAX and BAK, pro-apoptotic members of the BCL-2 family, responsible for the permeabilization of the mitochondrion outer membrane during apoptosis. The activation of BAX and BAK is also observed during 
intrinsic apoptosis and thus, represents a convergence point between intrinsic and extrinsic apoptosis (Rudel et al., 2010).

\subsection{INTRINSIC APOPTOSIS}

Contrary to extrinsic apoptosis which results from the interaction of a ligand and its receptor, intrinsic apoptosis is mediated by the mitochondrion following intracellular stress (Elmore, 2007) (Figure 7). This form of apoptosis is regulated by the pro-apoptotic proteins of the BCL-2 family. Intracellular stress will activate $\mathrm{BH} 3$-only effector proteins which will interact with the $\mathrm{BH} 3$ domains of $\mathrm{BAX}$ and $\mathrm{BAK}$. This will cause the recruitment of cytosolic BAX to the outer membrane of the mitochondrion and the stimulation the pore-forming ability of BAK, a protein anchored in the mitochondrial outer membrane. Oligomerization of BAX and BAK follows and results in the permeabilization of the mitochondrial membrane which causes a change in mitochondrial potential and release of pro-apoptotic proteins such as cytochrome $\mathrm{C}$ and second-mitochondrion derived activator of caspase (SMAC/Diablo) (Rudel et al., 2010). The amino acid residue Lys $_{72}$ of the cytochrome $\mathrm{C}$ will interact with the WD40 domain of the cytosolic protein apoptosis protease activating factor 1 (APAF-1) thus exposing the oligomerization $\mathrm{AAA}^{+}$domain of APAF-1. APAF-1 also contains a CARD, which following oligomerization of APAF-1, interacts with the CARD of procaspase-9. The complex comprised of the cytochrome C, oligomerized 
APAF-1, and procaspase- 9 is called the apoptosome. The formation of the apoptosome results in the activation of caspase-9, the initiator caspase of the intrinsic pathway, which in turn, cleaves procaspase-3 (Ow et al., 2008). Caspase-3 will then activate downstream targets resulting in cell death. SMAC is also capable of activating caspases- 9 and -8 by relieving the inhibitory effect of inhibitor of apoptosis protein (IAP) on them (Rudel et al., 2010). Caspases- 9 and -8 are both capable of cleaving procaspase- 3 into its active form, thus, the activation of caspase- 3 represents a convergence point between the intrinsic and extrinsic pathway. 


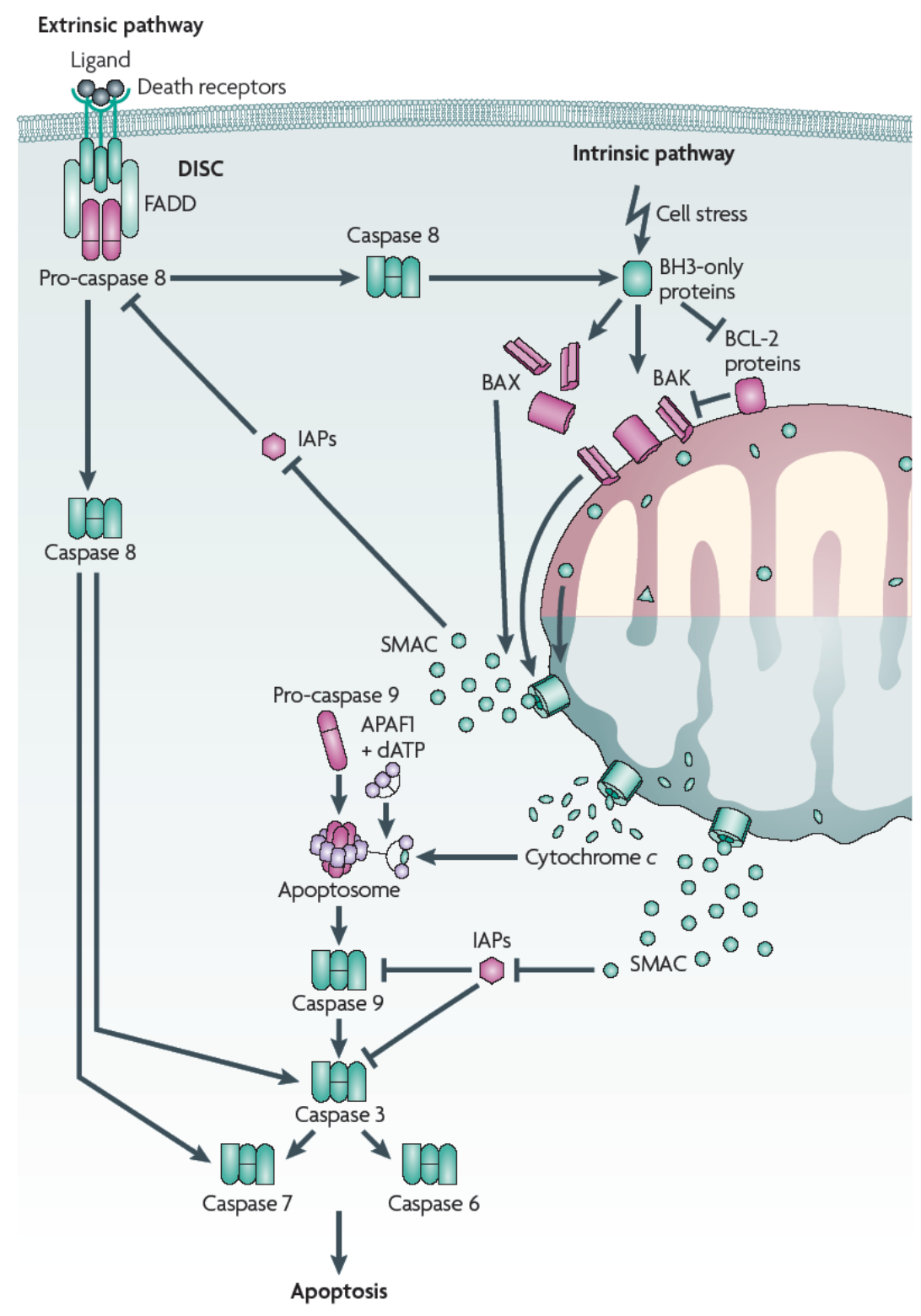

Figure 7: Extrinsic and intrinsic apoptotic pathways. Extrinsic apoptosis is stimulated following the interaction of a ligand and a receptor of the TNFR family leading to the formation of DISC. Caspase- 8 is then activated and activates downstream targets such as caspases-3 and -7. Intrinsic apoptosis is triggered as a result of intracellular stress activating $\mathrm{BH}$-only proteins such as $\mathrm{BAX}$ and BAK who in turn permeabilize the mitochondrion. Released cytochrome $\mathrm{C}$ binds with APAF-1 leading to the formation of the apoptosome and activation of caspase-9. Caspase-9 activates caspase- 3 resulting in the activation of downstream targets and eventual cell death. Extrinsic and intrinsic apoptosis converge at different points. Caspase- 8 can activate BH3only proteins responsible for mitochondrion membrane permeabilization. The 
mitochondrial pro-apoptotic protein SMAC relieves the inhibition of IAP allowing caspase- 8 activation. (Rudel et al., 2010)

\section{IMPLICATION OF IONS IN APOPTOSIS}

\subsection{Potassium}

Apoptotic volume decrease (AVD) is the term used to describe cell shrinkage occurring during apoptosis resulting from ion and water efflux (Maeno et al., 2000). Potassium was the ion first shown to be involved in AVD by Bortner et al. (1997) (Figure 8). The authors verified the implication of potassium in apoptosis following the observation made by Beauvais et al. (1995) that cytokine withdrawal from cultured eosinophils resulted in cell shrinkage which could be blocked by the potassium channel inhibitor 4-aminopyridime (Beauvais et al., 1995). However, the entire cell population, which consisted of mainly non-apoptotic cells, was examined by Beauvais et al. (1995), leading to a possible underestimation of the actual ion content change occurring in the apoptotic population. In order to circumvent this situation, Bortner et al (1997). investigated the change in potassium levels specifically in apoptotic cells using a fluorescent ion probe and flow cytometry. Apoptotic cells demonstrated a marked decrease in fluorescence compared to their nonapoptotic counterparts which indicated an important decrease in potassium levels in apoptotic cells. These shrunken cells also revealed caspase activation and DNA fragmentation when analyzed by flow cytometry. Treatment of cells 
with anti-Fas antibody, an inducer of apoptosis, in the presence of a potassium channel inhibitor abolished the occurrence of apoptosis indicating potassium efflux plays a role in the cell death.

Bortner and his team (1997) continued by determining if potassium efflux alone is sufficient to induce apoptosis. Cells were subjected to hypotonic conditions in the absence or presence of anti-Fas antibody. A lack of apoptosis was observed in cells exposed to hypotonic conditions in the absence of the anti-Fas antibody. On the other hand, cells exposed to hypotonic conditions and the anti-Fas antibody underwent apoptosis suggesting that potassium depletion alone does not induce apoptosis. However, cells subjected to hypotonic conditions and the anti-Fas antibody revealed higher levels of DNA fragmentation than cells treated with the anti-Fas antibody alone. According to the authors, this suggested that, in the presence of an apoptosis inducer, potassium efflux contributes to the progression of apoptosis (Bortner et al., 1997).

The role of potassium ions in apoptosis was demonstrated by Cain et al. (2001) who evaluated the effect potassium ions had on apoptosome formation and caspase activation. Physiological concentrations of potassium ions during non-apoptotic conditions have an inhibitory effect on caspase activation (Hughes et al., 1997). To verify this fact, cell lysates were incubated with dATP to trigger the activation of effector caspases-3 and -7 which was 
followed by exposure to increasing concentrations of potassium ions. Activation levels decreased sharply in the presence of increasing potassium ions indicating that potassium negatively impacts caspase activation. In order to determine if decreased activation levels was a result of structural changes in the caspases or a result of upstream molecules being inactivated, Western blots were conducted to determine the presence or absence of APAF-1 in cell lysates exposed to potassium ions. Western blots revealed a lack of APAF-1 in cell lysates exposed to potassium ions. This pointed to the possibility of inhibition of the formation of the apoptosome in the presence of elevated potassium levels (Cain et al., 2001). The authors verified this hypothesis by examining the oligomerization of purified APAF-1 in the presence of potassium ions and observed a lack of oligomerization. The inhibition of the formation of the apoptosome and lack of caspase activation in the presence of potassium ions observed by Cain et al. (2001) was also observed in a subsequent study (Beem et al., 2004). Taken together, the results obtained by Bortner et al. (1997), Cain et al. (2001), and Beem et al. (2004) demonstrate the involvement of potassium ions in apoptosis.

\subsection{CHLORIDE}

As potassium is the most abundant cation in cells and whose role in apoptosis has been described, speculation about the possible implication of chloride, the most abundant anion in cells, in cell death arose. Maeno et al. (2000) were 
interested in determining the involvement of chloride in cell death as a previous study revealed stimulation of Fas receptors resulted in the activation of chloride channels causing chloride efflux (Szabo et al., 1998). Cells treated with staurosporine demonstrated a decrease of intracellular levels of chloride ions measured using a fluorescent dyes specific to this ion resulting in cell shrinkage as determined by a Coutler-type cell size analyzer. The use of chloride channel inhibitors prevented the efflux of chloride ions as well as cell shrinkage, suggesting chloride efflux contributed to cell shrinkage. As cell shrinkage is a characteristic of apoptosis, Maeno et al. (2000) next verified the occurrence of apoptosis of cells exposed to staurosporine in the presence or absence of chloride channel inhibitors. Cells exposed to chloride channel inhibitors in the presence of staurosporine demonstrated a lack of apoptosis, characterized by the absence of caspase activation, whereas cells exposed to staurosporine but not to the channel inhibitors underwent apoptosis (Maeno et al., 2000). These results revealed for the first time that chloride efflux, like the potassium efflux observed by Bortner et al. (1997), is involved in cell death (Figure 8).

The time frame of cell shrinkage and apoptosis was then assessed by treating cells with staurosporine for different amounts of time and then examining cells for the occurrence of these events. Maeno et al. (2000) observed apoptotic volume decrease but not apoptosis after a two-hour treatment of cells with staurosporine. Caspase activation, accompanied by extensive cell shrinkage, 
was only detected after a six-hour treatment. These findings suggest that apoptotic volume decrease is an event occurring upstream of apoptosis and indicates that apoptotic volume decrease could be a requirement in the induction of apoptosis. Indeed, the studies conducted by Cain et al. (2001) and Beem et al. (2004) both demonstrated the requirement of the reduction of potassium levels in order for apoptosome formation and caspase activation to occur, suggested that cell shrinkage occurs first and is followed by the induction of apoptosis.

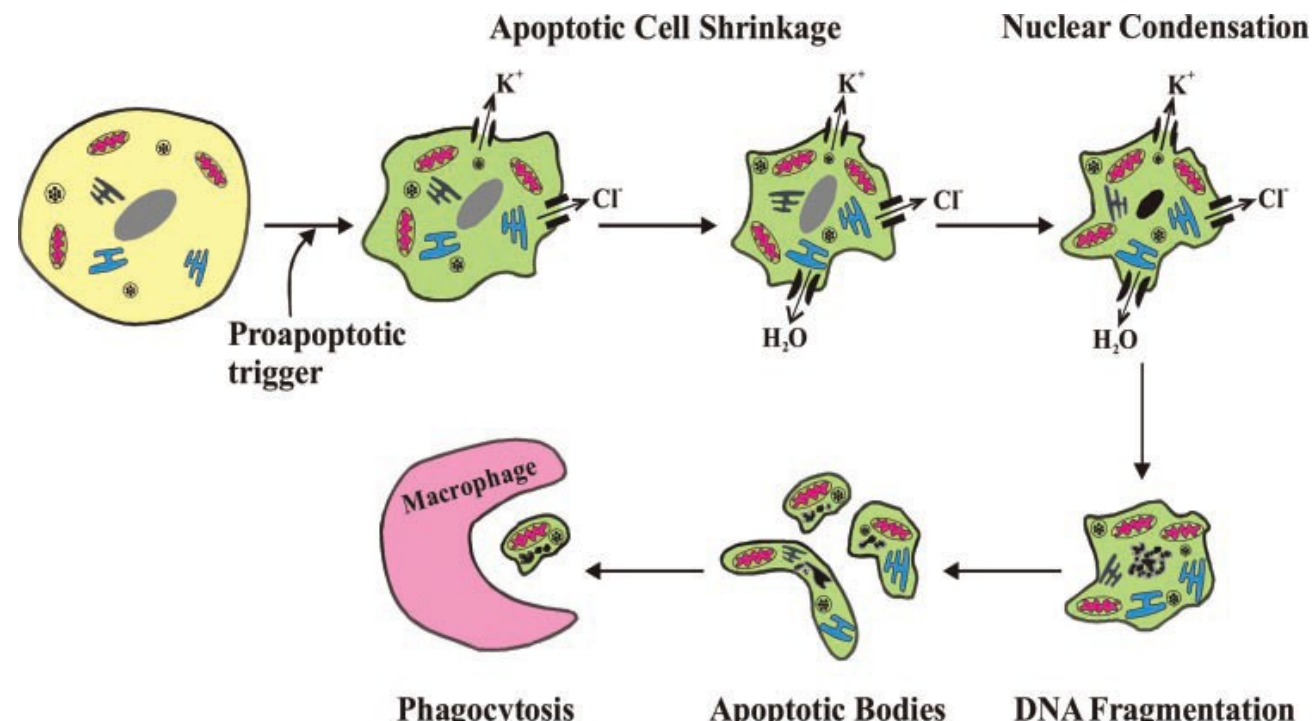

Figure 8: Cell shrinkage during apoptosis. Apoptotic cell shrinkage is the result of potassium, chloride, and water effluxes occurring following apoptotic stimuli. Cell shrinkage occurs upstream of nuclear condensation, DNA fragmentation, and apoptosis. Apoptotic bodies are eliminated via phagocytosis by macrophages. (Remillard et al., 2004) 


\subsection{CAlCiUm}

Calcium is a secondary messenger essential to the survival of eukaryotes implicated in the regulation of processes such as apoptosis and autophagy (Harr et al., 2010). Intracellular homeostasis of calcium is maintained by storing calcium ions in the endoplasmic reticulum and mitochondria (Rizzuto et al., 2006) as increases in intracellular calcium levels are detrimental to cell survival (Orrenius et al., 2003). A study conducted by Choi (1985) demonstrated that elevated intracellular calcium levels result in neurotoxicity. Neurons treated with glutamate, an amino acid capable of stimulating neuronal death, and placed in an extracellular medium void of calcium resulted in the absence of cell death. On the other hand, neurons treated with glutamate and placed in an extracellular medium containing calcium entered cell death. According to the author, these observations suggested that glutamate toxicity is dependent on the influx of calcium (Choi, 1985). These findings were confirmed in a subsequent study demonstrating that the N-methyl-d-aspartate (NMDA) class of receptors is responsible for the calcium influx leading to the toxicity of neurons causing their death (Choi, 1988).

Elevated intracellular levels leading to apoptosis has also been reported in prostate cancer cells (Martikainen et al., 1991) and in breast cancer cells (Jackisch et al., 2000) suggesting that programmed cell death arising from increased calcium levels occurs independently of cell type. Martikainen et al. 
(1991) observed that increases in cytosolic calcium levels in prostate cancer cells induced by a treatment with ionomycin, a calcium ionophore, led to the activation of an endonuclease resulting in DNA fragmentation and eventual cell death. Moreover, Jackish et al. (2000) also observed endonuclease activation in breast cancer cells treated with thapsigargin, an inhibitor of the endoplasmic reticulum Ca-ATPase pump which causes increases in cytosolic calcium levels, resulting in apoptosis. According to Jackish et al. (2000), this suggested that endonuclease activation is a result of increases in intracellular calcium levels. The activation of endonucleases following increases in intracellular levels of calcium observed by Martikainen et al. (1991) and by Jackish et al. (2000) demonstrated a role for calcium in programmed cell death.

Aside from activating endonucleases, calcium is also implicated in the permeabilization of the outer mitochondrial membrane (OMM) (Orrenius et al., 2003). Opening of the permeability transition pore (PTP) of the mitochondria was observed in hepatocytes treated with thapsigargin and resulted in changes in the permeabilization of the OMM (Hoek et al., 1997). The involvement of the PTP during apoptosis was demonstrated in a study by Petronilli et al. (2001). The authors revealed that the treatment of hepatocytes with cyclosporin A, an inhibitor of the PTP, prevented the release of proapoptotic proteins such as the cytochrome $\mathrm{C}$ and $\mathrm{AIF}$ from the mitochondrion, thus inhibiting programmed cell death (Petronilli et al., 2001). A subsequent 
study also demonstrated the role of PTP in the release of cytochrome C leading to mitochondrion-mediated apoptosis in hepatocytes (Morin et al., 2004).

\section{TOXINS INDUCING APOPTOSIS}

The ability of different types of toxins to induce apoptosis of eukaryotic cells has been documented by numerous studies in the literature. As STb is an enterotoxin and a pore-forming toxin, examples cited below will pertain to these types of toxins.

\subsection{ENTEROTOXINS}

\subsubsection{CLOSTRIDIUM DIFFICILE TOXIN A}

Apoptosis modulated by toxin A (TxA) was investigated in a study by Brito et al. (2002) which revealed that TxA is capable of inducing cell death in T-84 cells. The involvement of caspases in the apoptosis mediated by TxA was verified with the use of fluorescent substrates specific to caspases- $3,-6,-8$, and -9. All of these caspases were activated by TxA suggesting this toxin modulates apoptosis by more than one pathway. The implication of caspases was confirmed by the lack of apoptosis observed in cells treated with the pan caspase inhibitor, an inhibitor of all caspases, prior to being treated with TxA. Apoptosis induced by TxA also resulted in DNA fragmentation, cytochrome C 
release, and changes in mitochondrial membrane potential. The activation of caspase-9, cytochrome $\mathrm{C}$ release, and changes in mitochondrial membrane potential indicate TxA stimulates the intrinsic pathway of apoptosis. The implication of the extrinsic pathway was also confirmed by the activation of caspase- 8 and BID (Brito et al., 2002). The findings obtained by Brito et al. (2002) were subsequently confirmed by Carneiro et al. (2006) under both in vitro and in vivo conditions.

\subsubsection{ESCHERICHIA COLI LT TOXIN}

LT toxin has been reported to induce apoptosis in lymphocytes in a mouse model by Tamayo et al. (2009). The implication of the extrinsic pathway was confirmed with the use of mice expressing Fas-deficient lymphocytes which were treated with LT toxin and failed to undergo apoptosis. Lymphocytes expressing Fas, on the other hand, entered extrinsic apoptosis following exposure to LT toxin. Activation of the intrinsic pathway was verified by evaluating the involvement of caspase-3, PARP-1 cleavage, and annexin-V. Indeed, lymphocytes intoxicated with LT toxin demonstrated activation of caspase-3, cleavage of PARP-1, and positive binding of annexin-V, which according to the authors, suggested the involvement of the intrinsic pathway (Tamayo et al., 2009). The findings obtained by Tamayo et al. (2009) confirm the results obtained in a previous study (Tamayo et al., 2005). 


\subsection{PORE-FORMING ENTEROTOXINS}

\subsubsection{VIBRIO CHOLERAE CYTOLYSIN}

The apoptogenic potential of the pore-forming enterotoxin cytolysin was first demonstrated by Saka et al. (2008) in Caco-2 cells and in rabbit ileal loops. The activation of caspase-3 and DNA fragmentation, determined with the use of a fluorescent substrate and by agarose gel electrophoresis, respectively, was reported in Caco-2 cells treated with Vibrio cholerae strains positive for cytolysin (VCC) but negative for cholera toxin and with purified toxin. Caco-2 cells treated with VCC and pure cytolysin displayed morphological changes associated with apoptosis such as chromatin condensation, nuclear fragmentation, and membrane blebbing when observed by transmission electron microscopy. Rabbit intestines treated with VCC revealed DNA fragmentation as determined by TUNEL assay further confirming the ability of cytolysin to stimulate cell death (Saka et al., 2008)

\subsubsection{CLOSTRIDIUM PERFRINGENS ENTEROTOXIN}

The capacity of Clostridium perfringens enterotoxin (CPE) to mediate apoptosis of Caco-2 cells was evaluated by Chakrabarti and McClane (2005). Treatment of Caco-2 cells with pure CPE resulted in monolayer disruption, cell rounding, and membrane blebbing, when observed by electron 
microscopy, these morphological changes being associated with apoptosis. Intoxication of Caco-2 cells with enterotoxin also resulted in DNA laddering and activation of caspases -3 and -7 , as revealed by gel electrophoresis and the use of fluorescent substrates, respectively, hence, demonstrating the apoptotic potential of CPE. Changes in mitochondrial membrane potential of Caco-2 cells were also detected using flow cytometry, indicating apoptosis occurs through the intrinsic pathway (Chakrabarti et al., 2005).

\subsection{PORE-FORMING TOXINS}

\subsubsection{STAPHYLOCOCCUS AUREUS $\alpha$-TOXIN}

Bantel et al. (2001) demonstrated the ability of $\alpha$-toxin to induce apoptosis in Jurkat cells. Cell treatment of Jurkat cells with $\alpha$-toxin resulted in the activation of caspase-3 and DNA laddering determined with the use of a fluorescent substrate and by gel electrophoresis, respectively. The activation of caspase-9 and release of cytochrome $\mathrm{C}$ was also reported following intoxication of Jurkat cells with $\alpha$-toxin indicating the activation of the intrinsic pathway of apoptosis. The involvement of caspase-8 was also verified revealing a lack of activation of this caspase suggesting the extrinsic pathway is not implicated in the cell death modulated by $\alpha$-toxin (Bantel et al., 2001). The findings obtained by Bantel et al. (2001) would later be confirmed 
in another study demonstrating the involvement of the intrinsic pathway in the cell death of monocytes and Jurkat cells (Haslinger et al., 2003).

\subsubsection{HELICOBACTER PYLORI VACA}

The ability of VacA to modulate apoptosis in AGS cells was assessed in a study undertaken by Manente et al. (2008). AGS cells treated with pure VacA revealed activation of caspases-9, -8 , and -3 determined with the use fluorescent substrates indicating VacA stimulates the extrinsic and intrinsic apoptotic pathways. Activation of caspase-3 was also verified by Western blot as was cleavage of Retinoblatoma $(\mathrm{Rb})$. Flow cytometry analysis of cells treated with VacA toxin revealed cell cycle inhibition at the G1/S phases (Manente et al., 2008).

\section{PROJECT DESCRIPTION}

As stated above, some toxins possess the ability to kill eukaryotic cells via apoptosis. A previous study conducted in our laboratory by Goncalves et al. (2009) on the internalization process of STb toxin demonstrated that cultured cells having internalized STb displayed apoptotic-like morphology. Indeed, cell shrinkage, an alteration in the mitochondrial membrane potential, and membrane blebbing were the effects observed following STb uptake. 
However, DNA fragmentation was not observed by Goncalves et al. (2009) under the conditions tested.

The alteration of the mitochondrial membrane potential is a characteristic associated with the induction of the intrinsic pathway of apoptosis (Rudel et al., 2010). Moreover, Goncalves et al. (2009) observed colocalization of STb toxin with the mitochondrion in cells having internalized STb (Goncalves et al., 2009). Colocalization with the mitochondrion has also been reported for other toxins stimulating intrinsic apoptosis such as VacA of Helicobacter pylori (Galmiche et al., 2000) and PorB of Neisseria gonorrhoeae (Muller et al., 2000).

The colocalization of STb with the mitochondrion and the subsequent change in mitochondrial membrane potential and apoptotic-like morphology observed by Goncalves et al. (2009) allowed us to formulate the hypothesis that STb toxin could induce apoptosis via the intrinsic pathway. Our research objective, thus, consisted of verifying the ability of STb to induce intrinsic apoptosis. As $\mathrm{STb}$ is an enterotoxin, we selected the intestinal epithelial cells, HRT-18 and IEC-18 cells, as our cellular models of study. HRT-18 cells are human colon cancer cells used in apoptosis studies (Din et al., 2004). IEC-18 cells are rat ileum epithelial cells and were chosen since in vivo studies on STb are conducted in a rat model (Labrie et al., 2002). The results obtained during our study are presented in the next section. 
METHODOLOGY AND RESULTS 


\section{ARTiCLE}

Escherichia coli STb toxin induces apoptosis in intestinal epithelial cell lines

H. Claudia Syed and J. Daniel Dubreuil*

Groupe de recherche sur les maladies infectieuses du porc, Faculté de médecine vétérinaire, Université de Montréal, St-Hyacinthe, Québec, Canada.

*Corresponding author 
Abstract

A previous study conducted in our laboratory demonstrated that cells having internalized Escherichia coli heat stable toxin b (STb) toxin display apoptoticlike morphology. We therefore investigated if STb induces programmed cell death in both a human and an animal intestinal epithelial cell lines. HRT-18 (Human Colon Tumour) and IEC-18 (Rat Ileum Epithelial Cells) cell lines were used. As STb is frequently tested in a rat model, the IEC-18 cell line was most relevant to our work. The cell lines were treated with various amounts of purified STb (nanomole range) for a period of 24 hours after which cells were harvested and examined for apoptotic characteristics. Caspase-9, the initiator of mitochondrion-mediated apoptosis, and caspase-3, an effector of caspase-9, were both activated following STb intoxication of HRT-18 and IEC-18 cells whereas caspase-8, the initiator caspase of the extrinsic pathway, was not activated. For both cell lines, agarose gel electrophoresis of the cell DNA content reveals laddering of DNA, resulting from DNA fragmentation, a characteristic of apoptosis. Hoechst 33342-stained DNA of STb-treated cell lines, observed using fluorescence microscopy, revealed condensation and fragmentation of the nuclei. Apoptotic indexes calculated from fragmented nuclei of Hoechst 33342-stained DNA for HRT-18 and IEC-18 cells showed a $\mathrm{STb}$ dose-dependent response. Overall, these data indicate that STb toxin induces a mitochondrion-mediated caspase-dependent apoptotic pathway. 
Keywords: Apoptosis, caspase, DNA fragmentation, ETEC, STb toxin

\section{Highlights}

- $\quad$ Cell death induced by STb was revealed by DNA and nuclear fragmentation.

- $\quad$ STb-mediated death involves caspases-9 and -3, but not caspase-8.

- Intoxication of human and rat cells with STb results in cell death.

\section{Introduction}

Enterotoxigenic Escherichia coli (ETEC) represents an important cause of watery diarrhea in animals and in Man following the ingestion of contaminated food and water. ETEC is a common cause of travellers' diarrhea and can be fatal for children younger than 5 years old residing in developing countries [1]. Neonatal and suckling piglets less than one week old are particularly susceptible to diarrhea caused by ETEC bacteria [2]. ETEC-mediated diarrhea in young piglets is often sudden and severe, frequently resulting in death. Expression of both colonization factors and toxins is required for diarrhea to occur [3]. Heat-stable enterotoxin b (STb) is one of the toxins produced by ETEC strains responsible for the induction of diarrhea and is most commonly associated with post-weaning diarrhea in piglets aged over one week $[3,4]$. $\mathrm{STb}$ is synthesized as a pre-polypeptide of 71 amino acids $[5,6]$ which is 
cleaved in the periplasmic space to yield a mature peptide of 48 amino acids with a molecular weight of $5.2 \mathrm{kDa}$ [7]. Mature $\mathrm{STb}$ is comprised of two $\alpha-$ helices [8] joined by two disulfide bonds [9], a glycine-rich extended coil region [10], and a C-terminal oligomerization domain [11].

$\mathrm{STb}$-mediated diarrhea begins by $\mathrm{STb}$ binding to its receptor, sulfatide, an acidic glycosphingolipid found at the surface of intestinal epithelial cells [12]. $\mathrm{STb}$ is then internalized by cells resulting in the stimulation of a pertussis toxin-sensitive GTP-binding regulatory protein [13]. This causes an influx of extracellular calcium ions [13] through a receptor-dependent ligand-gated calcium channel activating calmodulin-dependent kinase II [14]. The increased calcium level is believed to stimulate the activities of phospholipases $\mathrm{A}_{2}$ and $\mathrm{C}$ and cause the release of arachidonic acid from membrane phospholipids leading to the formation of $\mathrm{PGE}_{2}$ and 5-HT. These molecules are responsible for the secretion of electrolytes such as $\mathrm{HCO}^{-}, \mathrm{Na}^{+}$, and $\mathrm{Cl}^{-}$, and water from enterocytes resulting in watery diarrhea [15-17].

Diarrhea mediated by STb was shown to be accompanied by histological damages of the intestine characterized by shortening and atrophy of the villi and reduced mucosal surface [18-20]. According to Rose et al. [20], these damages are responsible for fluid and water secretion and have been attributed to a diminished absorptive ability of the small intestine. As STb enterotoxin has been shown to induce the formation of non-specific pores in brush border 
membrane vesicles, STb could also be considered a pore-forming toxin [21]. Moreover, a previous study conducted in our laboratory demonstrated that cells in culture having internalized STb displayed apoptotic-like morphology such as cell shrinkage and a change in mitochondrial membrane potential [22] suggesting STb could have the capacity of inducing apoptosis. Indeed, the ability of enterotoxins [23] and pore-forming toxins [24] to induce apoptosis is well documented.

Apoptosis is a form of programmed cellular death characterized by cell shrinkage, preserved membrane integrity, caspase activation, and DNA fragmentation, which can be activated either through the extrinsic or intrinsic pathways [25]. Extrinsic apoptosis is triggered by the interaction of death ligands Fas Ligand (FasL) and Tumour Necrosis Factor Alpha (TNF- $\alpha$ ) with their respective death receptors, Fas Receptor (FasR) and Tumor Necrosis Factor Receptor (TNFR), members of the TNF receptor family [26]. The binding of TNF- $\alpha$ to TNFR results in the binding of TNF receptor-associated death domain (TRADD) which in turn recruits Fas Associated Death Domain (FADD) [25]. FADD associates with the Caspase Activation and Recruitment Domain (CARD) of procaspase-8, leading to the recruitment of this procaspase which results in the formation of Death-Inducing Signaling Complex (DISC). Proteolytic cleavage of procaspase- 8 then occurs giving way to caspase- 8 , the executioner caspase of extrinsic apoptosis. Caspase- 8 then cleaves 
procaspase-3 into caspase-3, which activates downstream targets leading to cell death $[26,27]$.

Intrinsic apoptosis occurs independently of the binding between a ligand and its transmembrane receptor [25]. This form of apoptosis is initiated by apoptotic stimuli activating $\mathrm{BH}$-only proteins which relieve the inhibition of proteins BCL-2-associated $\mathrm{X}$ protein (BAX) and BCL-2 homologous antagonist/killer (BAX) and allow their oligomerization. BAX and BAK then induce mitochondrial outer membrane permeabilization (MOMP) resulting in the release of the cytochrome $\mathrm{C}$ and other mitochondrial proteins [28]. Cytochrome $\mathrm{C}$ will associate with the WD40 domain of monomeric Apoptosis Protease Activating Factor-1 (APAF-1) exposing its $\mathrm{AAA}^{+}$oligomerization domain. APAF-1 oligomerizes into heptamers and then recruits procaspase-9 through its CARD, resulting in the formation of the apoptosome, the signalling platform of intrinsic apoptosis [27]. Procaspase-9, the initiator caspase of the mitochondrion pathway, is cleaved into caspase-9, which activates procaspase3. Caspase-3 will activate endonucleases responsible for DNA degradation leading to eventual cell death [26].

In this study, we sought to determine if STb toxin induces apoptosis in human and animal intestinal epithelial cell lines. As STb induced an alteration in mitochondrial membrane potential [22], our efforts were focused on determining if STb induced a mitochondrion-mediated apoptosis. 
Materials and Methods

Culture Media and Reagents. Roswell Park Memorial Institute (RPMI) medium, Dulbecco's Modified Eagle Medium (DMEM), Phosphate Buffered Saline (PBS), Fetal Bovine Serum (FBS), Penicillin/Streptomycin (Pen/Strep) and Trypan Blue were all purchased from Invitrogen (Burlington, Ontario, Canada). Bovine insulin was purchased from Alpha Diagnostics International (San Antonio, TX). Staurosporine was obtained from Sigma Aldrich (Oakville, Ontario, Canada). Caspases-9, -8 and-3 fluorescent substrates were purchased from Enzo Life Sciences (Farmingdale, NY).

Cell Lines. HRT-18 (Human Colon Tumour) cells were a kind gift from Dr. Carl Gagnon, Université de Montréal, and maintained in high-glutamine RPMI 1640 supplemented with $10 \%$ FBS and $1 \%$ Pen/Strep. IEC-18 (Rat Ileum Epithelial Cells) cells were purchased from ATCC (American Type Culture Collection) and cultivated in high-glucose and high-glutamine DMEM 12430 supplemented with 5\% FBS and $0.1 \%$ insulin. HRT-18 and IEC-18 cells were grown in T-75 culture flasks at $37^{\circ} \mathrm{C}, 5 \% \mathrm{CO}_{2}$ in a humidified incubator. Cell viability of both cell lines was measured using Trypan Blue. Tissue culture flasks (T-25 and T-75) were obtained from Sarstedt (St-Léonard, Québec, Canada). 
Production and purification of STb toxin. Recombinant STb toxin was produced using a HB101 strain harboring the plasmid pMAL-STb which codes for the fusion protein MBP-STb and is under the control of the promoter $\mathrm{P}_{\text {tac }}$ [29]. Ampicillin, at a final concentration of $50 \mu \mathrm{g} / \mathrm{ml}$, was used as the selection agent for bacteria carrying the plasmid pMAL-STb. Bacteria were grown in Rich Medium (10 g tryptone, $5 \mathrm{~g}$ yeast extract, $5 \mathrm{~g} \mathrm{NaCl}, 2 \mathrm{~g}$ dextrose per liter, containing $50 \mu \mathrm{g} / \mathrm{ml}$ of ampicillin) for 18 hours in an orbital shaker set at $37^{\circ} \mathrm{C}, 180 \mathrm{rpm}$. A volume of $5 \mathrm{ml}$ of an overnight bacterial culture was transferred to $500 \mathrm{ml}$ of fresh Rich Medium and returned to the orbital shaker for 2.5 hours. At a $\mathrm{DO}_{600}$ of $0.5, \mathrm{P}_{\text {tac }}$ promoter was induced by the addition of the lactose analogue, IPTG, at a final concentration of $0.3 \mathrm{mM}$. The induction was allowed to proceed for 3 hours in the orbital shaker. Bacteria were then harvested by centrifugation at $4000 \mathrm{xg}$ for 15 minutes at $4^{\circ} \mathrm{C}$. Cells were washed in a volume of $250 \mathrm{ml}$ of $30 \mathrm{mM}$ Tris- $\mathrm{HCl},(\mathrm{pH} 8), 20 \%$ sucrose, and 1 $\mathrm{mM}$ EDTA and were then centrifuged at $8000 \mathrm{x} g$ for 20 minutes at $4^{\circ} \mathrm{C}$. An osmotic shock of bacteria was induced using a solution of $5 \mathrm{mM} \mathrm{MgSO} 4$ containing $0.4 \mathrm{mM}$ PMSF and then centrifuged at $8000 \mathrm{x} g$ for 20 minutes at $4^{\circ} \mathrm{C}$. The $250 \mathrm{ml}$ supernatant, called osmotic shock fluid, was filter sterilized using a $0.22 \mu \mathrm{m}$ tangential flow filter (VacuCap, Pall Life Sciences, Port Washington, NY) and then loaded onto a $30 \mathrm{ml}$ amylose chromatography affinity column (NewEngland BioLabs, Pickering, Ontario, Canada) for 15 hours at a flow rate of $0.2 \mathrm{ml} / \mathrm{min}$ at $4^{\circ} \mathrm{C}$. A solution of $10 \mathrm{mM}$ maltose was used to elute the fusion protein which was then dialyzed against MilliQ water 
using a 12,000-14,000 Da membrane (Spectrum, Rancho Dominguez, CA). Dialyzed material was then concentrated and cleaved using the Xa enzyme in a cleavage buffer consisting of $100 \mathrm{mM} \mathrm{NaCl}, 50 \mathrm{mM}$ Tris- $\mathrm{HCl}, 1 \mathrm{mM} \mathrm{CaCl}$, ( $\mathrm{pH}$ 8). Cleaved material was separated using reverse-phase high performance liquid chromatography with a $\mathrm{C}_{8}$ microbore column (Perkin Elmer, Montréal, Québec, Canada) and an AKTA-10 purifier system (GE Healthcare, Baie d'Urfé, Québec, Canada). The purity of the STb recombinant toxin was verified with SDS-PAGE and the identity of the toxin was confirmed by protein dot blots.

Apoptosis assays. Cells were seeded in T25 culture flasks and grown to $70 \%$ confluence prior to treatment with various amounts of pure STb toxin ranging from 0.05 to $1 \mathrm{nmol}$ (nanomoles). Cells treated with $2 \mu \mathrm{M}$ of staurosporine were our positive control for apoptosis whereas our negative control consisted of untreated cells. For gel electrophoresis experiments, cells treated with $1 \mathrm{mM}$ of hydrogen peroxide served as a positive control for necrosis. Following treatment, cells were washed with PBS, trypsinized, centrifuged at $6000 \mathrm{xg}$ for 10 minutes, and used for the experiments described below.

Gel Electrophoresis. Electrophoresis was carried out according to a modified version of McGahon's method [30]. Briefly, cells were harvested and lysed in $2 \mathrm{mM}$ EDTA, $100 \mathrm{mM}$ Tris-HCl, (pH 8.0), and 0.8\% SDS. Samples were then treated with $50 \mathrm{mg} / \mathrm{ml} \mathrm{RNase} \mathrm{A} \mathrm{for} 1$ hour at $37^{\circ} \mathrm{C}$ and then with $20 \mathrm{mg} / \mathrm{ml}$ 
Proteinase $\mathrm{K}$ for 1.5 hours at $50^{\circ} \mathrm{C}$. A DNA loading buffer (4X TBE buffer containing $40 \%$ sucrose and $0.25 \%$ bromophenol blue) was added to samples to a final concentration of $1 \mathrm{X}$ which were loaded onto $1.8 \%$ agarose gels prepared in $1 \mathrm{X}$ TBE buffer $(89 \mathrm{mM}$ tris base, $89 \mathrm{mM}$ boric acid, and $2 \mathrm{mM}$ trisodium EDTA) and were then pre-stained with $10 \mathrm{mg} / \mathrm{ml}$ ethidium bromide. Migration of samples was carried out at $100 \mathrm{~V}$ for 75 minutes using a GNC100 apparatus (Pharmacia Biotech Piscataway, NJ). Gels were then visualized under a UV lamp at $260 \mathrm{~nm}$.

Hoechst Staining. Treated cells were harvested and fixed in 4\% paraformaldehyde prepared in PBS, $(\mathrm{pH} 7.4)$. Samples were transferred onto microscope slides and allowed to air dry. A $10 \mu \mathrm{g} / \mathrm{ml}$ working solution of Hoechst 33342 was used to stain samples. Staining was allowed to proceed for 10 minutes at room temperature in the dark. Slides were washed with water and allowed to air dry in the dark at room temperature. Samples were rehydrated in PBS and visualized by fluorescence microscopy at $460 \mathrm{~nm}$.

Dose-Response Assay. Cells were treated with 0.05, 0.1, 0.25, 0.5 and $1 \mathrm{nmol}$ of pure STb toxin for 24 hours. Harvested cells were then fixed, stained, and visualized as described in the Hoechst 33342 staining procedure. Fragmented nuclei were counted and divided by total number of nuclei and then multiplied by 100 to obtain the apoptotic indexes. 
Fluorometric Assay of Caspase Activation. Enzymatic activity of caspases-9, 8 , and -3 was measured using fluorescent substrates specific for each of these caspases. Following cell treatment, cells were harvested and lysed in ice-cold buffer (50 mM HEPES, $100 \mathrm{mM} \mathrm{NaCl}, 0.1 \%$ CHAPS, 1 mM DTT, (pH 7.4)) for 15 minutes and then pulse-sonicated with a microtip for 10 seconds (Branson Sonifier 450, Danbury, CT) until cells were lysed. Samples were then centrifuged at $5800 \times \mathrm{g}$ for 15 minutes. Protein content of the supernatant was dosed using the Bradford method (BioRad, Hercules, CA) with bovine serum albumin (BSA) as the reference protein. A total of $50 \mu \mathrm{g}$ of protein was loaded into a well of a 96-well flat-bottomed microplate (Linbro, McLean, VA) in assay buffer (50 mM HEPES, $100 \mathrm{mM} \mathrm{NaCl}, 0.1 \%$ CHAPS, $10 \%$ glycerol, $(\mathrm{pH} 7.4))$. The substrate was added at a final concentration of $200 \mu \mathrm{M}$. The final volume in the wells was adjusted to $100 \mu 1$ by adding the appropriate volume of assay buffer. The enzymatic reaction was allowed to proceed for 3 hours at room temperature in the dark. The fluorescence emitted from the cleaved substrates was then measured using a fluorescence microplate reader (Biotek, Winooski, VT) and the Gen5 program using 400 $\mathrm{nm}$ and $500 \mathrm{~nm}$ excitation and emission filters, respectively.

Statistical Analysis. A one-way ANOVA with dose as the factor was done. A priori contrasts were used to compare dose means with respect to the lowest dose. Comparisonwise error rates were calculated using the sequential 
Bonferroni procedure. The familywise error rate was set at 0.05 . SAS v 9.2 (Cary, NC) was used for the statistical analyses.

Results

Activation of caspases-9 and -3 but not -8 is involved in STb-mediated apoptosis

Caspases-8 and -9 are initiator caspases associated with the extrinsic and mitochondrion-mediated apoptotic pathways, respectively, and are responsible for the activation of caspase-3 [31]. Thus, the evaluation of the activation of initiator caspases can be used to determine the apoptotic pathway(s) involved. HRT-18 cells and IEC-18 cells treated with 0.05 and $0.5 \mathrm{nmol}$ of STb toxin revealed activation of caspases-9 and -3 , as well as staurosporine, our positive control for apoptosis (Fig. 1 and 2). On the other hand, levels of caspase-8 observed were similar to our negative control which consisted of untreated cells indicating the lack of activation of caspase- 8 in both cell lines (Fig. 1 and 2).

$\mathrm{STb}$ induces DNA fragmentation

DNA Fragmentation Factor (DFF) is a key endonuclease activated by caspase3 during apoptosis responsible for the degradation of internucleosomal DNA 
[32] into fragments multiples of 180 to $200 \mathrm{bp}$ [33]. The DNA extracted from HRT-18 and IEC-18 cells following treatment with STb revealed DNA laddering when migrated in agarose gel as observed with staurosporine, our positive control for apoptosis (Fig. 3). The DNA fragments observed ranged in sizes from 500 to $1000 \mathrm{bp}$, these being approximate multiples of 180 to 200 bp, and appeared evenly distributed in the gel. These results were confirmed using fluorescence microscopy. In fact, cells stained with the DNA-specific Hoechst 33342 stain revealed condensed and fragmented nuclei while the negative control, consisting of untreated cells, showed normal nuclei morphology (Fig. 4).

Dose-dependent effect of STb

Treatment of cells with increasing amounts of STb toxin ranging from 0.05 to 1 nanomol revealed a dose-dependent response as determined by the apoptotic indexes recorded (Fig. 5). The apoptotic indexes of HRT-18 cells treated with $\mathrm{STb}$ toxin increased and leveled to approximately $14 \%(\mathrm{p}<0.001)$. For IEC-18 cells, indexes leveled at $13 \%(\mathrm{p}<0.001)$. Although the apoptotic indexes attained with both cell lines are similar, HRT-18 cells seemed more responsive to lower amounts of STb toxin than IEC-18 cells. 


\section{Discussion}

The results presented in the current study show the ability of STb toxin to induce apoptosis in both a human and an animal intestinal epithelial cell lines. The ability of enterotoxins to cause apoptosis using the mitochondrionmediated pathway has been shown with LT of Escherichia coli [34] and toxin A of Clostridium difficile [23]. Aside from enterotoxins, pore-forming toxins such as Staphylococcus aureus $\alpha$-toxin [35] and PorB of Neisseria gonorrhoeae [36] also induce intrinsic apoptosis. HRT-18 cells were chosen as they are extensively used in apoptosis studies [37, 38]. IEC-18 cells, on the other hand, were chosen since in vivo studies conducted on STb are often undertaken using a rat model as an alternative to the pig. The use of two cell lines also allowed us to verify if the ability of STb to induce apoptosis is a cell type-specific phenomenon and to demonstrate that human cell lines could also possibly respond to $\mathrm{STb}$.

The activation of caspase-9 in cellular extracts of HRT-18 and IEC-18 cells treated with $\mathrm{STb}$ (Fig. 1 and 2) and the alteration of the mitochondrion membrane potential observed by Gonçalves et al. [22] in cells treated with STb were strong indications of $\mathrm{STb}$ targeting the mitochondrion-mediated death pathway. The activation of caspase- 9 and -3 observed in HRT-18 and IEC-18 cells indicates that $0.05 \mathrm{nmol}$ is sufficient for caspase activation by STb. The activation of both the extrinsic and intrinsic pathways by Helicobacter pylori 
VacA has been reported [39] prompting us to verify the implication of the extrinsic pathway in STb-mediated apoptosis. Both cell lines treated with STb toxin revealed a lack of caspase- 8 activation (Fig. 1 and 2), thus excluding the involvement of the extrinsic pathway for STb. Taken together, the activation of caspase- 9 but lack of caspase- 8 activation implies that STb mediates apoptosis solely through the intrinsic pathway.

Caspase- 3 is the first effector caspase activated by initiator caspases during apoptosis, hence, its activation following $\mathrm{STb}$ treatment confirms the implication of caspases during STb-mediated apoptosis. Caspase-3 is a key caspase activated during caspase-dependent apoptosis which possesses multiple targets such as DFF, Ca-ATPase [40], Poly (ADP-ribose) polymerase (PARP), and proteins of the cytoskeleton [41].

DNA extracted from STb-treated human and rat cell lines revealed fragments multiples of 180 to 200 bp (Fig. 3). The even distribution of fragments suggests cleavage is occurring at regular intervals. Indeed, the endonuclease DFF cleaves internucleosomal DNA yielding evenly distributed fragments. Thus, it appears that the fragmented DNA observed by gel electrophoresis during STb-mediated apoptosis is the result of cleavage by DFF. Supporting this observation, Hoecsht 33342-stained DNA of STb-treated cells revealed fragmented nuclei (Fig. 4). Overall, the DNA laddering and the condensation 
and fragmentation of nuclei observed support that DNA damage occurs as a result of STb-mediated apoptosis.

Maximal apoptotic indexes of $14 \%$ and $13 \%$ were obtained for HRT-18 and IEC-18 cells, respectively (Fig. 5). However, the smaller quantity of toxin required for the induction and the attainment of a plateau in HRT-18 cells suggests that these cells could be more susceptible to apoptosis. A dosedependent response towards STb was observed in both cell lines.

As previously stated, caspase-3 cleaves the Ca-ATPase pump during apoptosis causing a deregulation of calcium homeostasis manifested by an influx of calcium ions [41, 42]. The activation of caspase-3 observed in our study could therefore be partially responsible for the influx of calcium observed during STb-mediated diarrhea [13] suggesting a link between the diarrheagenic and apoptotic pathways stimulated by $\mathrm{STb}$. Indeed, studies conducted on Clostridium perfringens enterotoxin revealed that this toxin is capable of increasing intracellular calcium levels during both diarrhea [43] and apoptosis [44] and of inducing histological damages to the intestine [43] similar to the ones observed for $\mathrm{STb}$ [20]. Contrary to calcium levels which rise during apoptosis, chloride levels decrease. Chloride efflux has been shown to be essential for caspase activation to occur during intrinsic apoptosis [45]. Thus, the chloride secretion characteristic of STb-induced diarrhea could play a role in the activation of caspases observed in the current study. Cytolysin of Vibrio 
cholerae, like enterotoxin, possesses the capacity of inducing apoptosis and histological damages during diarrhea [46]. Furthermore, the inhibition of the apoptosis mediated by toxin A of Clostridium difficile resulted in reduced fluid accumulation and mucosal disruption of rabbit intestinal loops [23] providing additional evidence of diarrhea and apoptosis relationship. Thus, the apoptosis described in this study could be partially responsible for the loss of absorptive capacity of intestinal cells following STb treatment.

\section{Conclusions}

We have shown, for the first time, that STb induces intrinsic apoptosis in both a human and an animal epithelial cell lines. This indicates that in vivo rat cells, our model, as well as human cell lines can be intoxicated by STb, thus representing a new argument to consider STb as a toxic molecule responsible for diarrhea in humans [47]. The cell death reported here can be partially responsible for the loss of absorptive capacity and fluid accumulation observed in ligated intestinal loops during diarrhea indicating that diarrhea and apoptosis could be linked. 


\section{References}

[1] Kaper JB, Nataro JP, Mobley HL. Pathogenic Escherichia coli. Nat Rev Microbiol 2004;2:123-40.

[2] Nagy B, Fekete PZ. Enterotoxigenic Escherichia coli (ETEC) in farm animals. Vet Res 1999;30:259-84.

[3] Dubreuil JD. Escherichia coli STb enterotoxin. Microbiology $1997 ; 143: 1783-95$.

[4] Fairbrother JM, Nadeau E, Gyles CL. Escherichia coli in postweaning diarrhea in pigs: an update on bacterial types, pathogenesis, and prevention strategies. Anim Health Res Rev 2005;6:17-39.

[5] Lee CH, Moseley SL, Moon HW, Whipp SC, Gyles CL, So M. Characterization of the gene encoding heat-stable toxin II and preliminary molecular epidemiological studies of enterotoxigenic Escherichia coli heatstable toxin II producers. Infect Immun 1983;42:264-8.

[6] Picken RN, Mazaitis AJ, Maas WK, Rey M, Heyneker H. Nucleotide sequence of the gene for heat-stable enterotoxin II of Escherichia coli. Infect Immun 1983;42:269-75.

[7] Kupersztoch YM, Tachias K, Moomaw CR, Dreyfus LA, Urban R, Slaughter C, et al. Secretion of methanol-insoluble heat-stable enterotoxin (STB): energy- and secA-dependent conversion of pre-STB to an intermediate indistinguishable from the extracellular toxin. J Bacteriol 1990;172:2427-32. 
[8] Sukumar M, Rizo J, Wall M, Dreyfus LA, Kupersztoch YM, Gierasch LM. The structure of Escherichia coli heat-stable enterotoxin b by nuclear magnetic resonance and circular dichroism. Protein Sci 1995;4:1718-29.

[9] Fujii Y, Hayashi M, Hitotsubashi S, Fuke Y, Yamanaka H, Okamoto K. Purification and characterization of Escherichia coli heat-stable enterotoxin II. J Bacteriol 1991;173:5516-22.

[10] Dreyfus LA, Urban RG, Whipp SC, Slaughter C, Tachias K, Kupersztoch YM. Purification of the STB enterotoxin of Escherichia coli and the role of selected amino acids on its secretion, stability and toxicity. Mol Microbiol 1992;6:2397-406.

[11] Labrie V, Harel J, Dubreuil JD. Oligomerization of Escherichia coli enterotoxin $b$ through its $\mathrm{C}$-terminal hydrophobic $\alpha$-helix. Biochim Biophys Acta $2001 ; 1535: 128-33$.

[12] Rousset E, Harel J, Dubreuil JD. Binding characteristics of Escherichia coli enterotoxin $\mathrm{b}(\mathrm{STb})$ to the pig jejunum and partial characterization of the molecule involved. Microb Pathog 1998;24:277-88.

[13] Dreyfus LA, Harville B, Howard DE, Shaban R, Beatty DM, Morris SJ. Calcium influx mediated by the Escherichia coli heat-stable enterotoxin B (STB). Proc Natl Acad Sci U S A 1993;90:3202-6.

[14] Fujii Y, Nomura T, Yamanaka H, Okamoto K. Involvement of $\left.\mathrm{Ca}^{2+}\right)$ calmodulin-dependent protein kinase II in the intestinal secretory action of Escherichia coli heat-stable enterotoxin II. Microbiol Immunol 1997;41:633-6. 
[15] Harville BA, Dreyfus LA. Involvement of 5-hydroxytryptamine and prostaglandin $\mathrm{E}_{2}$ in the intestinal secretory action of Escherichia coli heatstable enterotoxin B. Infect Immun 1995;63:745-50.

[16] Hitotsubashi S, Fujii Y, Yamanaka H, Okamoto K. Some properties of purified Escherichia coli heat-stable enterotoxin II. Infect Immun $1992 ; 60: 4468-74$.

[17] Peterson JW, Whipp SC. Comparison of the mechanisms of action of cholera toxin and the heat-stable enterotoxins of Escherichia coli. Infect Immun 1995;63:1452-61.

[18] Whipp SC, Moseley SL, Moon HW. Microscopic alterations in jejunal epithelium of 3-week-old pigs induced by pig-specific, mouse-negative, heatstable Escherichia coli enterotoxin. Am J Vet Res 1986;47:615-8.

[19] Whipp SC, Kokue E, Morgan RW, Rose R, Moon HW. Functional significance of histologic alterations induced by Escherichia coli pig-specific, mouse-negative, heat-stable enterotoxin (STb). Vet Res Commun 1987;11:4155.

[20] Rose R, Whipp SC, Moon HW. Effects of Escherichia coli heat-stable enterotoxin b on small intestinal villi in pigs, rabbits, and lambs. Vet Pathol $1987 ; 24: 71-9$

[21] Goncalves C, Vachon V, Schwartz JL, Dubreuil JD. The Escherichia coli enterotoxin STb permeabilizes piglet jejunal brush border membrane vesicles. Infect Immun 2007;75:2208-13. 
[22] Goncalves C, Dubreuil JD. Effect of Escherichia coli STb toxin on NIH3 T3 cells. FEMS Immunol Med Microbiol 2009;55:432-41.

[23] Carneiro BA, Fujii J, Brito GA, Alcantara C, Oria RB, Lima AA, et al. Caspase and bid involvement in Clostridium difficile toxin A-induced apoptosis and modulation of toxin A effects by glutamine and alanylglutamine in vivo and in vitro. Infect Immun 2006;74:81-7.

[24] Carrero JA, Calderon B, Unanue ER. Listeriolysin O from Listeria monocytogenes is a lymphocyte apoptogenic molecule. J Immunol 2004;172:4866-74.

[25] Elmore S. Apoptosis: a review of programmed cell death. Toxicol Pathol 2007;35:495-516.

[26] Duprez L, Wirawan E, Vanden Berghe T, Vandenabeele P. Major cell death pathways at a glance. Microbes Infect 2009;11:1050-62.

[27] Ow YP, Green DR, Hao Z, Mak TW. Cytochrome C: functions beyond respiration. Nat Rev Mol Cell Biol 2008;9:532-42.

[28] Youle RJ, Strasser A. The BCL-2 protein family: opposing activities that mediate cell death. Nat Rev Mol Cell Biol 2008;9:47-59.

[29] Bosse M, Handl CE, Lortie LA, Harel J, Dubreuil JD. Fusion of the genes encoding Escherichia coli heat-stable enterotoxin b (STb) and the maltosebinding protein to obtain mature STb enterotoxin. J Gen Microbiol. $1993 ; 139: 631-8$. 
[30] McGahon AJ, Martin SJ, Bissonnette RP, Mahboubi A, Shi Y, Mogil RJ, et al. The end of the (cell) line: methods for the study of apoptosis in vitro. Methods Cell Biol 1995;46:153-85.

[31] Fink SL, Cookson BT. Apoptosis, pyroptosis, and necrosis: mechanistic description of dead and dying eukaryotic cells. Infect Immun 2005;73 190716.

[32] Widlak P, Garrard WT. Roles of the major apoptotic nuclease-DNA fragmentation factor-in biology and disease. Cell Mol Life Sci 2009;66:26374.

[33] Liu X, Zou H, Slaughter C, Wang X. DFF, a heterodimeric protein that functions downstream of caspase-3 to trigger DNA fragmentation during apoptosis. Cell 1997;89:175-84.

[34] Tamayo E, Postigo J, Del Giudice G, Rappuoli R, Benito A, Yagita H, et al. Involvement of the intrinsic and extrinsic cell-death pathways in the induction of apoptosis of mature lymphocytes by the Escherichia coli heatlabile enterotoxin. Eur J Immunol 2009;39:439-46.

[35] Bantel H, Sinha B, Domschke W, Peters G, Schulze-Osthoff K, Janicke RU. $\alpha$-toxin is a mediator of Staphylococcus aureus-induced cell death and activates caspases via the intrinsic death pathway independently of death receptor signaling. J Cell Biol 2001;155:637-48.

[36] Kozjak-Pavlovic V, Dian-Lothrop EA, Meinecke M, Kepp O, Ross K, Rajalingam $\mathrm{K}$, et al. Bacterial porin disrupts mitochondrial membrane potential and sensitizes host cells to apoptosis. PLoS Pathog 2009;5:e1000629. 
[37] Din FV, Dunlop MG, Stark LA. Evidence for colorectal cancer cell specificity of aspirin effects on NF kappa B signalling and apoptosis. $\mathrm{Br} \mathrm{J}$ Cancer 2004;91:381-8.

[38] Tao GZ, Rott LS, Lowe AW, Omary MB. Hyposmotic stress induces cell growth arrest via proteasome activation and cyclin/cyclin-dependent kinase degradation. J Biol Chem 2002;277:19295-303.

[39] Manente L, Perna A, Buommino E, Altucci L, Lucariello A, Citro G, et al. The Helicobacter pylori's protein VacA has direct effects on the regulation of cell cycle and apoptosis in gastric epithelial cells. J Cell Physiol 2008;214:582-7.

[40] Schwab BL, Guerini D, Didszun C, Bano D, Ferrando-May E, Fava E, et al. Cleavage of plasma membrane calcium pumps by caspases: a link between apoptosis and necrosis. Cell Death Differ 2002;9:818-31.

[41] Rudel T, Kepp O, Kozjak-Pavlovic V. Interactions between bacterial pathogens and mitochondrial cell death pathways. Nat Rev Microbiol 2010;8:693-705.

[42] Paszty K, Antalffy G, Hegedus L, Padanyi R, Penheiter AR, Filoteo AG, et al. Cleavage of the plasma membrane $\mathrm{Ca}^{+}$ATPase during apoptosis. Ann $\mathrm{N}$ Y Acad Sci 2007;1099:440-50.

[43] McClane BA, Hanna PC, Wnek AP. Clostridium perfringens enterotoxin. Microb Pathog 1988;4:317-23. 
[44] Chakrabarti G, McClane BA. The importance of calcium influx, calpain and calmodulin for the activation of $\mathrm{CaCo}-2$ cell death pathways by Clostridium perfringens enterotoxin. Cell Microbiol 2005;7:129-46.

[45] Heimlich G, Cidlowski JA. Selective role of intracellular chloride in the regulation of the intrinsic but not extrinsic pathway of apoptosis in Jurkat Tcells. J Biol Chem 2006;281:2232-41.

[46] Saka HA, Bidinost C, Sola C, Carranza P, Collino C, Ortiz S, et al. Vibrio cholerae cytolysin is essential for high enterotoxicity and apoptosis induction produced by a cholera toxin gene-negative $V$. cholerae non-O1, non-O139 strain. Microb Pathog 2008;44:118-28.

[47] Albert MA, Dubreuil JD. Nouvelles observations appuyant le rôle de la toxine STb d'Escherichia coli dans la diarrhée chez l'Homme. In: Benoit E, Goudey-Perriere F, Marchot P, Servent D. Toxines et fonctions choloinergiques neuronales et non neuronales, Paris: Société Française pour l'Etude des Toxines; 2008, p. 101-4.

Acknowledgments

This work was funded by a grant from the National Science and Engineering Research Council of Canada (NSERC) to JDD. HCS would like to thank Marco Langlois for assistance in preparing the figures. 


\section{Figure Legends}

Figure 1: Caspase activation in HRT-18 cells treated with STb. Activation of caspases-9 and -3 , but not -8 , was observed in HRT-18 cells treated with 0.05 and $0.5 \mathrm{nmol}$ of pure STb for 24 hours. The negative control consisted of untreated cells while the positive control consisted of cells treated with $2 \mu \mathrm{M}$ of staurosporine. Mean \pm standard error of 2 independent experiments.

Figure 2: Caspase activation in IEC-18 cells treated with STb. Activation of caspases- 9 and -3 , but not -8 , was observed in IEC-18 cells treated with 0.05 and $0.5 \mathrm{nmol}$ of pure STb for 24 hours. The negative control consisted of untreated cells while the positive control consisted of cells treated with $2 \mu \mathrm{M}$ of staurosporine. Mean \pm standard error of 2 independent experiments.

Figure 3: Gel electrophoresis of DNA extracted from HRT-18 (A) and IEC-18 (B) cells treated with STb for 24 hours demonstrates DNA laddering. A: untreated cells (negative control) (lane 1), cells treated with staurosporine (apoptosis control) (lane 2), 1 nmol of STb (lane 3), and hydrogen peroxide (necrosis control) (lane 4), respectively. B: untreated cells (lane 1), cells treated to 0.25 and $0.5 \mathrm{nmol}$ of STb, respectively, (lanes 2 and 3), and cells treated with staurosporine (lane 4). M denotes the molecular weight markers for both gels. Their size is shown in bp at the left of the gels. The band 
506,517 in the molecular weight markers denotes a band composed of two bands, one of $506 \mathrm{bp}$ and the other of $517 \mathrm{bp}$.

Figure 4: Condensed and fragmented nuclei are observed in HRT-18 cells (B) and IEC-18 cells (D) treated with 1 and 0.5 nmol of STb, respectively. Nuclei of untreated HRT-18 cells (A) and IEC-18 cells (C) are also shown. Pictures were taken at $40 \mathrm{x}$.

Figure 5: STb induces dose-dependent apoptosis in HRT-18 cells $(p<0.001$; one-way ANOVA) and IEC-18 cells ( $<<0.001$; one-way ANOVA). Apoptotic index is expressed as percentages of the number of fragmented nuclei divided by the total number of nuclei. Mean \pm standard error of 2 independent experiments. 
Figures

Figure 1
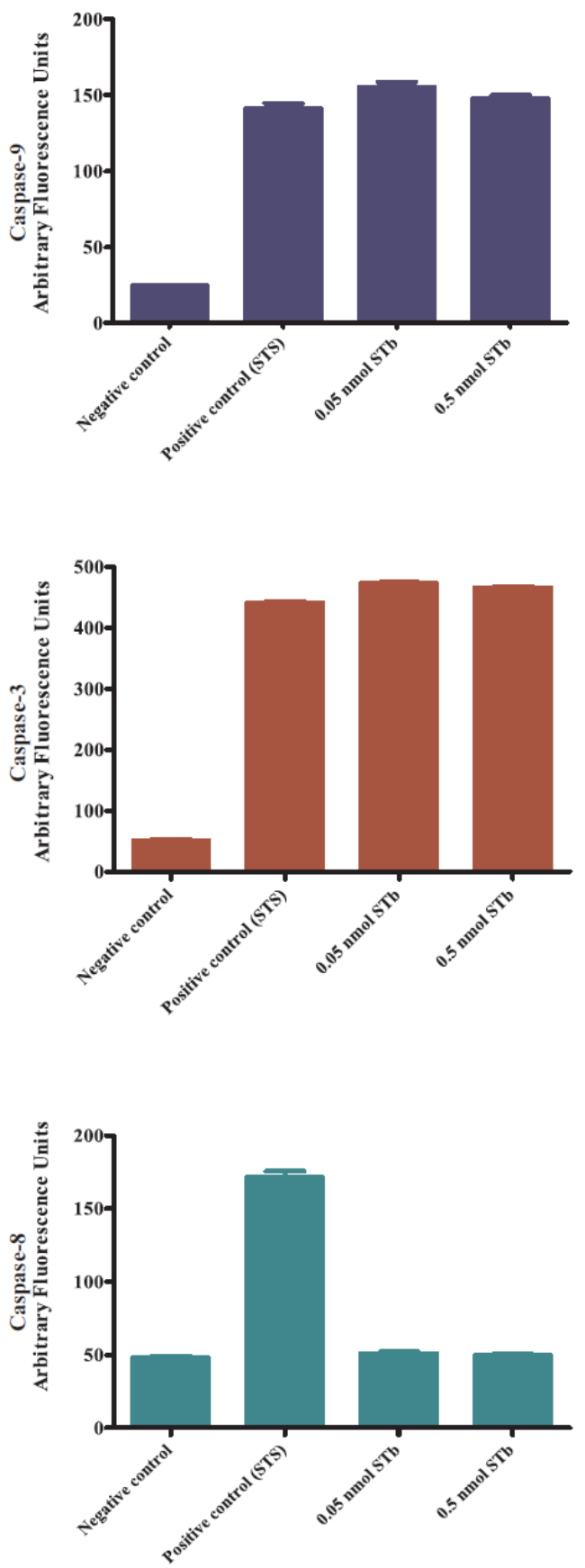
Figure 2
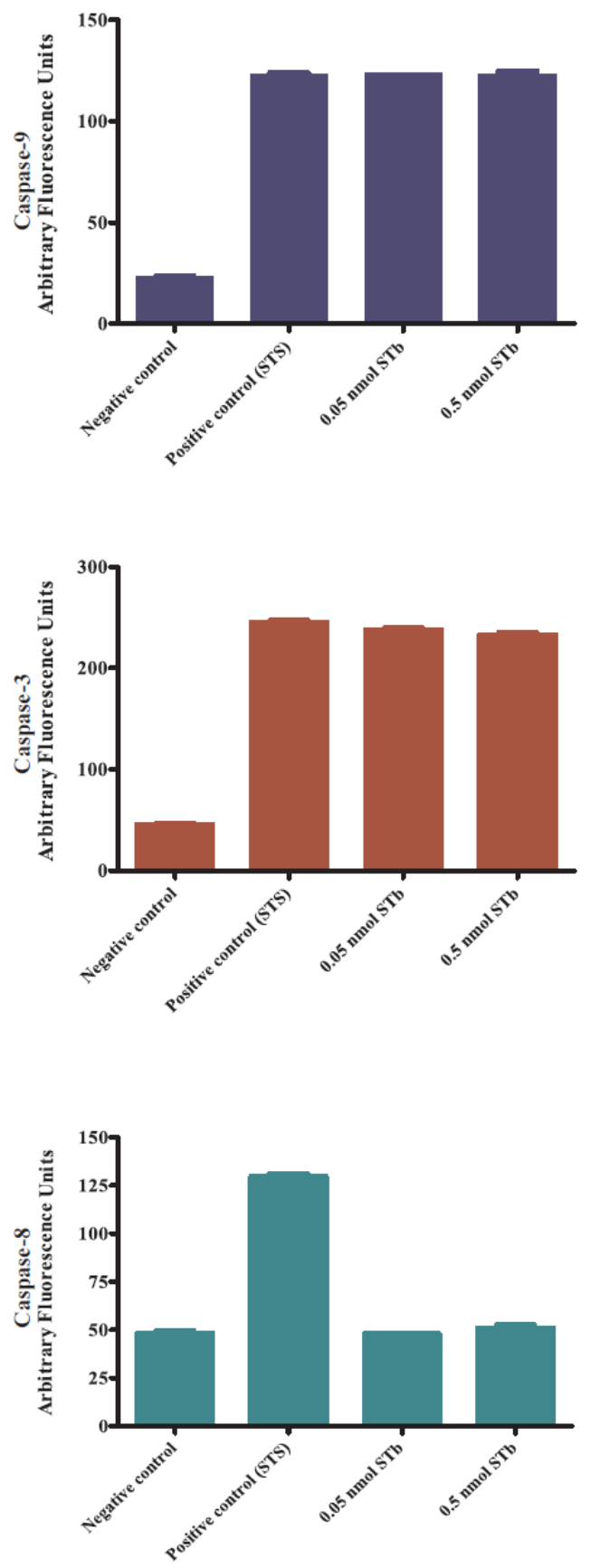
Figure 3
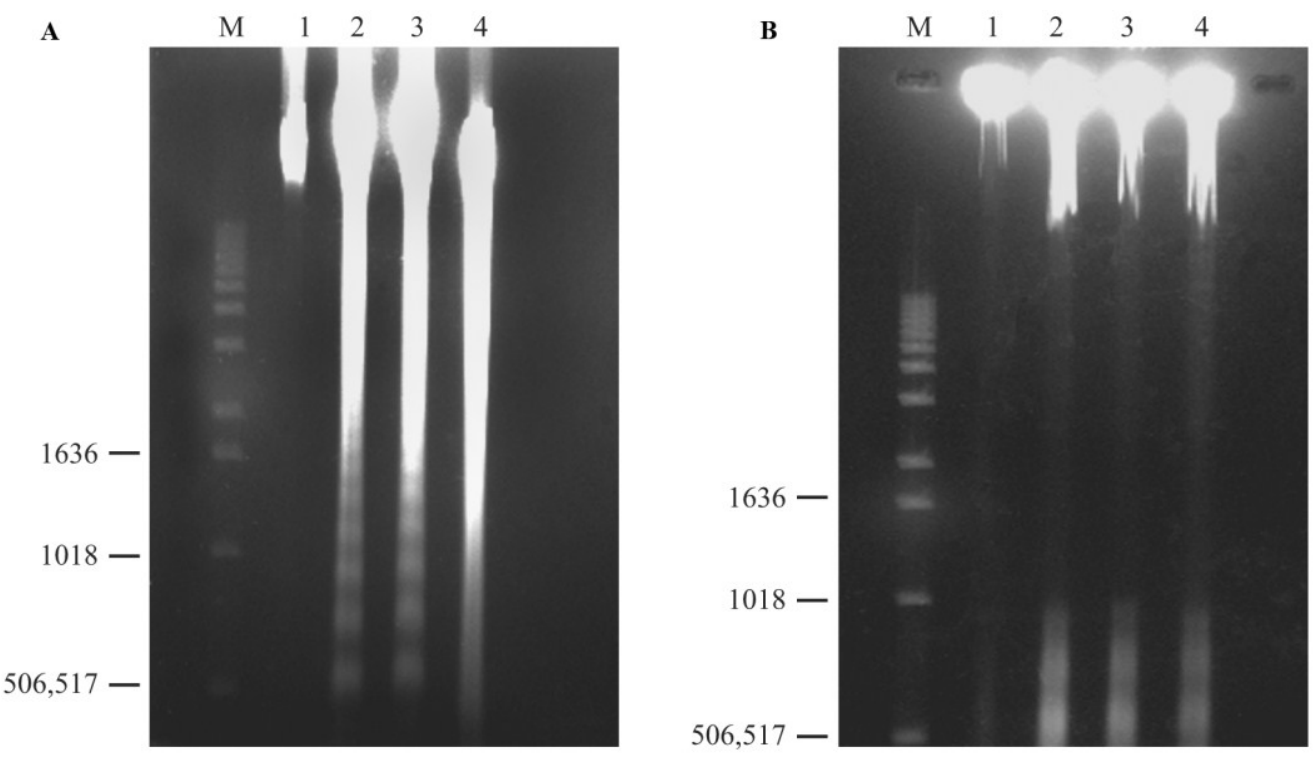
Figure 4

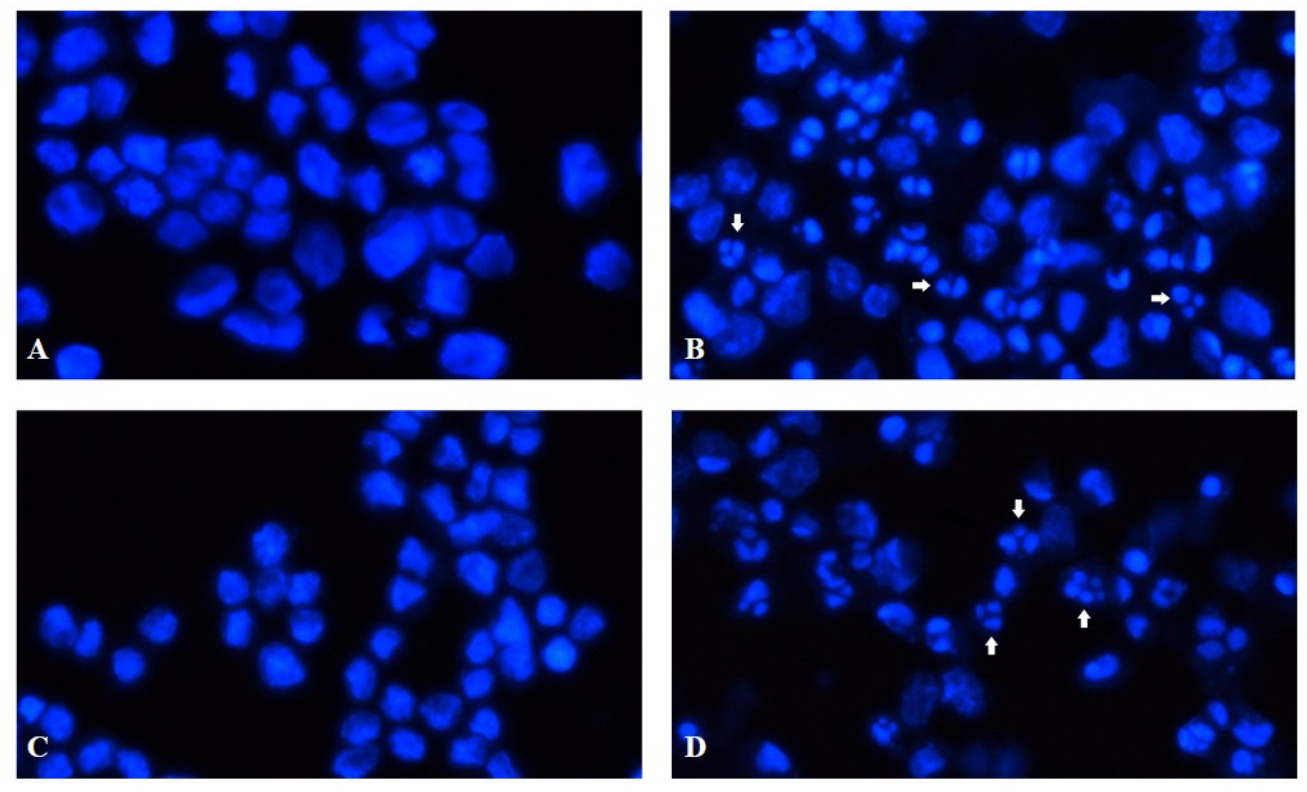


Figure 5
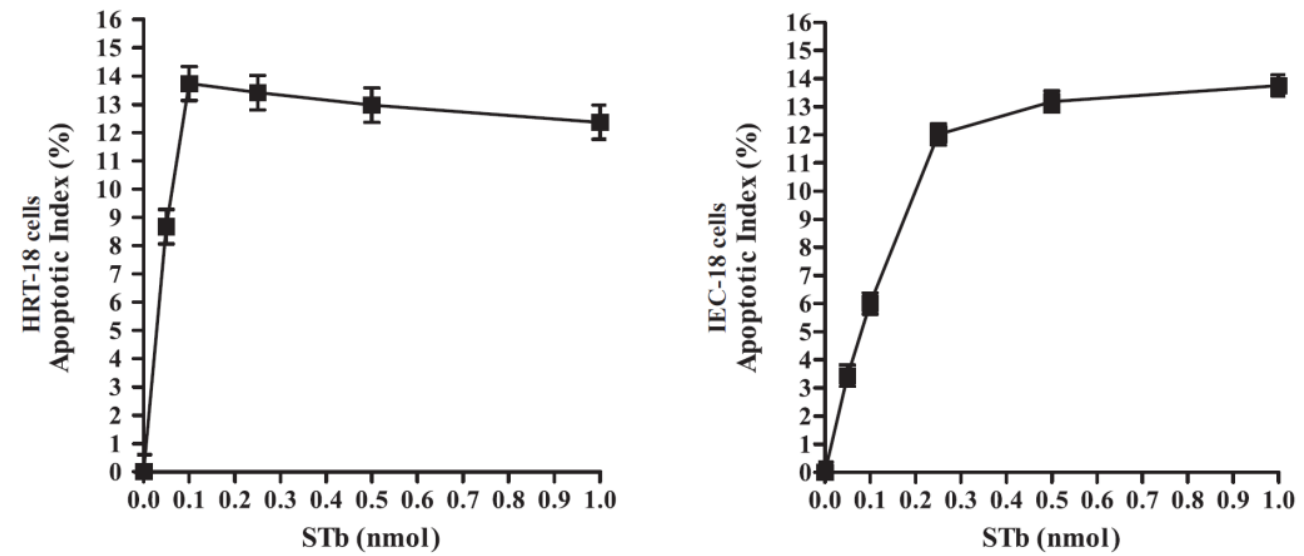
DISCUSSION 


\section{Cell Type ANd Apoptosis}

The goal of this study consisted in evaluating the ability of STb toxin to induce apoptosis in HRT-18 and IEC-18 cell lines. The HRT-18 cell line is a human colon carcinoma cell which is extensively used in apoptosis studies (Din et al., 2004). The IEC-18 cell line is a rat ileum epithelial cell line which has been used in previous studies in our laboratory, hence, this cell line was selected due to its susceptibility to STb toxin. The results obtained in this study clearly demonstrate the induction of apoptosis in HRT-18 and IEC-18 cells indicating that apoptosis mediated by STb occurs independently of the cell type used. In addition, this indicates that human intestinal epithelial cells respond in the same way as rat cells, our model for carrying out in vivo studies on STb.

The induction of intrinsic apoptosis requires the internalization of the virulence factors or intracellular pathogens and the interaction with the mitochondrion in order for this cell death pathway to be triggered (Rudel et al., 2010). A study evaluating the internalization process of STb in NIH-3T3 cells, demonstrated that cells having internalized STb displayed apoptotic-like morphology characterized by an alteration of the mitochondrial membrane potential, cell shrinkage, and membrane blebbing (Goncalves et al., 2009). The lack of DNA fragmentation observed by Goncalves et al. (2009) could be attributed to NIH-3T3 cells being less susceptible to STb than HRT-18 and IEC-18 cells. NIH-3T3 cells are murine fibroblasts and therefore do not 
represent the natural target of STb toxin, the intestine, as do the HRT-18 and IEC-18, intestinal epithelial cell lines. Moreover, the decreased susceptibility of murine cells to $\mathrm{STb}$ compared to rat cells has been observed in a previous study (Whipp, 1990) and could partially explain the occurrence of apoptosis in IEC-18 cells but not in NIH-3T3 cells.

The apoptosis of HRT-18 cells induced by STb toxin predicts a greater role for $\mathrm{STb}$ than previously assumed in the virulence of ETEC bacteria. As previously shown, strains expressing STb do not necessarily cause diarrhea in humans (Echeverria et al., 1985). The lack of diarrhea has been attributed to the lack of presence of fimbriae required for adhesion to the intestinal mucosa (Lortie et al., 1991, Gaastra et al., 1996). The role of STb in swine diarrhea was demonstrated in a study by Berberov et al. (2004) who revealed that $60 \%$ of piglets inoculated with an ETEC $\mathrm{STb}^{+} \mathrm{EAST1}^{+} \mathrm{LT}^{-}$strain developed diarrhea (Berberov et al., 2004). This finding was confirmed by Zhang et al. (2006) who observed fluid accumulation in piglets injected with $\mathrm{F}^{+} \mathrm{STb}^{+}$positive strains. Fluid accumulation decreased substantially in piglets injected with $\mathrm{F}^{+}$ $\mathrm{STb}^{-}$negative strains. According to the authors, this proved that $\mathrm{STb}$ contributes to the virulence associated with ETEC bacteria (Zhang et al., 2006). Taken together, the findings obtained by Berberov et al. (2004) (Berberov et al., 2004) and Zhang et al. (2006) as well as the cell death of HRT-18 cells reported here shed new light on the contribution of STb to ETEC pathogenesis. 


\section{CASPASE INVOLVEMENT IN STb-MEDIATED APOPTOSIS}

The implication of caspases in the apoptosis induced by STb in HRT-18 and IEC-18 cells was verified as caspase activation is a key event in cell death. Caspases-9 and -3 were both activated in these cells following treatment with $\mathrm{STb}$ toxin. The activation of caspase- 9 we observed as well as the change in mitochondrial potential observed by Goncalves et al. (2009) are indications of $\mathrm{STb}$ mediating apoptosis via the intrinsic pathway. Studies conducted on the pore-forming $\alpha$-toxin of Staphylococcus aureus (Bantel et al., 2001) and on toxin A of Clostridium difficile (Carneiro et al., 2006) have demonstrated changes in mitochondrion membrane potential and activation of caspase-9. Thus, STb appears to trigger apoptosis in a similar way. The implication of extrinsic apoptosis by VacA of Helicobacter pylori (Manente et al., 2008) and LT of Escherichia coli (Tamayo et al., 2009) has been reported prompting us to verify the involvement of this pathway following STb intoxication. The lack of caspase- 8 activation observed in these cell lines demonstrates that the extrinsic pathway is not involved in the apoptosis induced by STb under our experimental conditions.

The activation of caspases during intrinsic apoptosis depends on the reduction of the intracellular level of chloride ions. Chloride secretion and histological damages of the intestines have been observed in the diarrhea caused by CPE (McDonel, 1974) and VCC (Debellis et al., 2009) as is observed during STb- 
mediated diarrhea (Dreyfus et al., 1993). Moreover, both CPE (Chakrabarti et al., 2005) and VCC (Saka et al., 2008) have the capacity to activate the caspase cascade during intrinsic apoptosis. Thus, the chloride secretion observed during diarrhea caused by STb could be partially responsible for the caspase activation obtained in this study indicating a link between diarrhea and apoptosis.

Aside from chloride secretion, the processes of diarrhea and apoptosis can be linked through increases in the levels of intracellular calcium. Indeed, caspase-3 is a key effector caspase activated during apoptosis responsible for the cleavage of the Ca-ATPase pump resulting in an influx of calcium ions (Schwab et al., 2002). Increased calcium intracellular levels is observed during diarrhea and apoptosis mediated by CPE (Chakrabarti et al., 2005). Thus, the increases in intracellular calcium levels observed during diarrhea stimulated by STb (Dreyfus et al., 1993) could be another link between diarrhea and apoptosis.

Increased intracellular calcium levels during apoptosis can lead to the activation of the protease calpain (Orrenius et al., 2003). The study conducted by Chakrabarti and McClane (2005) evaluating the apoptogenic potential of CPE also demonstrated the implication of calpain in the cell death modulated by this toxin. Similarly, the involvement of calpain has been reported in the cell death stimulated by Shiga toxin, a toxin known to increase intracellular 
calcium levels during apoptosis (Johannes et al., 2010). Though not verified in the present study, the cell death mediated by STb could also be the result of calpain activation following augmentation in intracellular calcium levels during diarrhea, again implying the processes of diarrhea and apoptosis could be linked.

\section{FRAGMENTATION OF DNA AND NUCLEI BY STb}

DNA extracted from HRT-18 and IEC-18 cells following STb treatment revealed laddering as observed by gel electrophoresis. DNA fragmentation is a distinctive feature associated with the process of apoptosis and is the result of the cleavage of internucleosomal DNA by DFF, an endonuclease activated by caspase-3 which generates fragments multiples of $180 \mathrm{bp}-200 \mathrm{bp}$ (Liu et al., 1997). The fragments observed by gel electrophoresis are approximate multiples of $180 \mathrm{bp}-200 \mathrm{bp}$ and are evenly distributed on the gels. Hence, fragmentation of DNA occurs at regularly spaced intervals and appears to be the result of cleavage by DFF. Hoechst 33342-stained DNA of HRT-18 and IEC-18 cells treated with STb revealed condensed and fragmented nuclei when observed by fluorescence microscopy confirming the results observed by gel electrophoresis. Taken together, these results confirm that apoptosis is mediated by STb. Indeed, DNA laddering has also been observed in apoptosis stimulated by VCC (Saka et al., 2008). 


\section{APOPTOSIS INDUCED BY STb IS DOSE-DEPENDENT}

Apoptotic indexes based on fragmented nuclei of HRT-18 and IEC-18 cells treated with increasing amounts of STb toxin revealed cell death occurs in a dose-dependent manner. An apoptotic index of 14\% was obtained for HRT-18 cells treated with $0.1 \mathrm{nmol}$ of STb whereas a $13 \%$ index was reported for IEC18 cells treated with $0.25 \mathrm{nmol}$ of toxin. This suggests that 0.1 and $0.25 \mathrm{nmol}$ of $\mathrm{STb}$ are sufficient quantities to saturate HRT-18 and IEC-18 cells, respectively. The dose-dependent response obtained in the current study is in accordance with previous studies conducted by Goncalves et al. $(2007 ; 2009)$ demonstrating STb induces changes in mitochondrial membrane potential in a dose-dependent manner. Moreover, the quantities of 0.1 and $0.25 \mathrm{nmol}$ of STb used in our study to attain a plateau of apoptosis occurrence, are higher than the $0.8 \mathrm{nmol}$ used in a previous study to demonstrate $\mathrm{CHO}$ cells remain viable after intoxication by STb (Beausoleil et al., 2002a). We believe the viability of $\mathrm{CHO}$ cells following $\mathrm{STb}$ treatment results from the short duration of the treatment, a period of 2 hours, compared to the 24-hour treatment of HRT-18 and IEC-18 cells used in our study.

The apoptotic indexes of HRT-18 and IEC-18 cells obtained in our study, though similar, indicate HRT-18 cells are slightly more susceptible to STb toxin than IEC-18 cells which represent our in vivo model. These observations contrast with the findings obtained by Beausoleil et al. (2002a) who had 
evaluated the susceptibility of various cell lines to STb and demonstrated that IEC-18 cells were more susceptible to STb than HT-29 cells, the human cell line tested by the authors. The receptor for STb toxin, sulfatide, is an ubiquitous molecule present at the surface of many different cell types. It is tempting to speculate about the possibility that HRT-18 cells express a greater number of sulfatide molecules at their surface than IEC-18 cells which could render them more susceptible to STb. However, a study by Albert et al. (2011) demonstrated that the presence of sulfatide at the cell surface has no effect on the internalization of STb by different cell types (Albert et al., 2011), an essential step in STb pathogenesis. As such, the presumed differences in the presence of sulfatide molecules at the cell surface of HRT-18 and IEC-18 cells could not explain the greater susceptibility of HRT-18 cells to STb toxin.

\section{APOPTOSIS INDUCTION BY ENTERIC PATHOGENS}

Infection of intestinal epithelial cells with enteric pathogens, either invasive or noninvasive, results in these cells undergoing apoptosis. The reasons for the occurrence of apoptosis following bacterial infection of epithelial cells are currently being debated. Nonetheless, one of two divergent reasons for cell death have been purposed: 1) elimination of infected cells by the host or 2) gaining deeper access to the mucosa to prolong colonization by pathogens (Hausmann, 2010). In the first case, programmed cell death is a strategy employed by the host to eliminate cells infected with invasive enteric 
pathogens. Apoptosis limits the intracellular replication of such pathogens thus inferring with the pathogenesis of invasive enteric pathogens (Kim et al., 1998). As ETEC bacteria are not invasive, it seems unlikely that the apoptosis of intestinal epithelial cells induced by STb is an attempt of the host to eliminate infected cells.

As stated above, apoptosis of intestinal epithelial cells has also been suggested as a way of enteric pathogens of gaining deeper access to the mucosa (Hausmann, 2010). Indeed, intestinal epithelial cells produce mucin (McGuckin et al., 2011) and express Toll-Like Receptors 4 (TLR-4) (Gribar et al., 2008), both of which are implicated in the prevention of the spread of infections caused by enteric pathogens. As such, the apoptosis of these cells abolishes the prevention of the spread of enteric pathogenic and results in these pathogens gaining a deeper access to underlying mucosa. The gut mucosa is considered an attractive target for enteric pathogens as infection of the mucosa results in the induction of an inflammatory response. This inflammatory response renders colonization of the mucosa by commensal strains difficult (Stecher et al., 2011) and leads to increased colonization by pathogenic Enterobacteriae contributing to the pathogenesis of these microorganisms (Lupp et al., 2007).

Furthermore, the replacement of columnar intestinal epithelial cells by cuboidal or squamous cells following STb action (Rose et al., 1987) seems to 
support the idea of $\mathrm{STb}^{+}$ETEC strains gaining access to the mucosa. Columnar cells are implicated in the secretion of mucin (McGuckin et al., 2011) which has been shown to possess the capacity of binding enteric pathogens such as Citrobacter rodentium to limit their spread (Linden et al., 2008). The replacement of columnar cells with cuboidal or squamous cells results in reduced mucin secretion as these cell types do not produce mucin (McGuckin et al., 2011). Mucin depletion confers an advantage to pathogens seeking access to the mucosa. Thus, it seems that the apoptosis of intestinal epithelial cells caused by STb as well as the replacement of columnar cells with cuboidal or squamous cells could be a strategy used by $\mathrm{STb}^{+}$ETEC strains to gain access to the mucosa. 
CONCLUSION 
The results presented in this thesis demonstrate the ability of STb toxin to induce apoptosis in human and rat intestinal epithelial cells. The apoptosis modulated by $\mathrm{STb}$ is a caspase-dependent phenomenon as activation of caspases-9 and -3 were observed in HRT-18 and IEC-18 cells. The implication of caspase- 9 demonstrates the stimulation of the intrinsic pathway as has been observed by other enterotoxins and pore-forming toxins indicating that $\mathrm{STb}$ induces cell death similarly to other toxins. DNA laddering and nuclear condensation and fragmentation were also observed in HRT-18 and IEC-18 cells following STb treatment implying STb causes DNA damage responsible for cell death. Apoptotic indexes revealed dose-dependent responses.

The apoptosis observed in HRT-18 cells is an exciting finding as it indicates human cells can be intoxicated by STb and respond in a similar way to STb as rat cells, our in vivo model for studying STb. Thus, this result represents a new argument to consider $\mathrm{STb}$ as a toxic molecule responsible for the development of diarrhea in humans and demonstrates a more important role for $\mathrm{STb}$ in the pathogenesis of ETEC in humans than previously assumed (Albert et al., 2008). As well, the apoptosis in HRT-18 cells induced by STb encourages the assessment of the effects of STb in other human cell lines and in human tissues. 
The results presented here demonstrated the apoptogenic potential of $\mathrm{STb}$ toxin in both human and rat intestinal epithelial cells in in vitro conditions. This constitutes an important limitation of our study as in vitro conditions do not fully mimic in vivo conditions. However, the use of in vitro conditions simplified data interpretation and allowed us to verify our hypothesis before proceeding to the more complicated step of using in vivo models.

The programmed cell death presented here could be partially responsible for the fluid accumulation observed in ligated intestinal loops as well as the loss of absorptive capacity associated with diarrhea induced by STb. Thus, the evaluation of the apoptosis mediated by STb in in vivo conditions would allow us to determine a link between the diarrhea and apoptosis caused by STb. 
FUTURE DIRECTIONS 


\section{Cell CyCle anAlysis}

The processes of apoptosis and cell cycle progression are linked by mechanisms which currently remain elusive (Clarke et al., 2009). Bacterial toxins and effectors capable of modulating cell cycle progression are known as cyclomodulins (Nougayrede et al., 2005). Helicobacter pylori VacA toxin (Manente et al., 2008) and TxA (Carneiro et al., 2006, Nottrott et al., 2007) are toxins which cause intrinsic apoptosis and interfere with cell cycle progression. Moreover, Goncalves et al. (2009) reported the observation of enlarged nuclei in NIH-3T3 cells treated with $\mathrm{STb}$, a characteristic associated with cell cycle inhibition at the G2/M phases (Lin et al., 2004). However, interference with cell cycle progression by STb was not evaluated in the study conducted by Goncalves et al. (2009). Hence, the ability of STb to act as a cyclomodulin requires further investigation.

Indeed, both EHEC and EPEC produce a cyclomodulin known as cycle inhibiting factor (Cif) which arrests the process of mitosis thus resulting in the inhibition of the cell cycle progression at the G2/M phases (Marches et al., 2003). Additionally, the cytolethal distending toxin produced by pathogenic E. coli has been shown to interfere with cell cycle progression also at the G2/M phases (Elwell et al., 2001). Cell cycle inhibition at the G2/M phases has been proposed as a mechanism which disrupts cell renewal and developmental processes of the intestinal epithelium. Consequently, cell 
shedding fails to occur therefore allowing prolonged colonization and invasion by pathogenic bacteria (Nougayrede et al., 2005). Furthermore, subsequent studies revealed the induction of apoptosis by both Cif (Samba-Louaka et al., 2009) and cytolethal distending toxin (Jinadasa et al., 2011). Thus, it seems that the induction of apoptosis and the interference with the progression of the cell cycle appear to be linked in their contribution to the pathogenesis of enteric bacteria as both promote colonization and are executed by the same virulence factors.

\section{INVOLVEMENT OF OLIGOMERIZATION IN APOPTOSIS INDUCTION}

The capacity to form oligomers is a common characteristic shared by poreforming toxins mediating apoptosis through the intrinsic pathway such as Staphylococcus aureus $\alpha$-toxin (Bhakdi et al., 1991) and Helicobacter pylori VacA (Adrian et al., 2002). Indeed, Labrie et al. (2002) demonstrated STb mutants in the C-terminal region, the domain responsible for oligomer formation, exhibited reduced enterotoxicity. Thus, the implication of oligomer

formation in the modulation of cell death by STb could be evaluated in a future study and would permit a greater understanding of the structurefunction relationship required for STb toxicity. 


\section{APOPTOSIS IN IN VIVO CONDITIONS}

The induction of apoptosis by $\mathrm{STb}$ toxin was studied here in in vitro conditions. Fluid accumulation and histological damages occurring during diarrhea mediated by $\mathrm{STb}$, on the other hand, have been observed in in vivo conditions with the use of ligated animal intestines. CPE (Chakrabarti et al., 2005, McDonel, 1974) and VCC (Saka et al., 2008) are enterotoxins capable of modulating apoptosis and of causing histological damages similar to the ones observed during STb-mediated diarrhea. Additionally, the inhibition of apoptosis modulated by TxA resulted in decreased fluid accumulation (Carneiro et al., 2006), suggesting a link between diarrhea and apoptosis. The evaluation of apoptosis in in vivo conditions would permit to establish and/or confirm a link between diarrhea and apoptosis.

\section{DEVELOPMENT OF A LOCAL APOPTOSIS INHIBITOR}

Glutamine is considered essential to the maintenance of the proper development and functioning of the intestinal epithelial cells in the gut. Indeed, glutamine has been shown to be implicated in acid-base homeostasis, gluconeogenesis, nitrogen transport, and synthesis of proteins and nucleic acids of intestinal epithelial cells (Roth et al., 2002). Moreover, glutamine has also been shown to exert a beneficial effect on gut mucosa by reducing apoptosis of intestinal epithelial cells (Ban et al., 2010) induced by oxidants 
(Jones, 2002). Glutamine is also beneficial to the improvement of gut barrier function and gut immune responses (Roth et al., 1996). Glutamine starvation, on the other hand, is associated with the occurrence of apoptosis of intestinal epithelial cells (Larson et al., 2007), villous atrophy and mucosal ulcerations (Labow et al., 2000).

As glutamine has been shown to protect intestinal epithelial cells from oxidant-induced apoptosis, Carneiro et al. (2006) investigated the ability of glutamine to inhibit apoptosis induced by TxA. Indeed, glutamine treatment of intestinal epithelial cells prior to intoxication with TxA resulted in the lack of caspase activation both in vitro and in vivo. Fluid secretion and mucosal disruption associated with TxA were also reduced by glutamine treatment (Carneiro et al., 2006) indicating glutamine inhibits apoptosis and reduces the effects of diarrhea mediated by TxA. As STb toxin induces apoptosis of intestinal epithelial cells as well as fluid secretion and reduction in mucosal surfaces during diarrhea, glutamine could represent a potential prophylactic treatment for the prevention of apoptosis and the resulting histopathologies caused by STb. 
REFERENCES 
Adrian, M., Cover, T.L., Dubochet, J. and Heuser, J.E. (2002). Multiple oligomeric states of the Helicobacter pylori vacuolating toxin demonstrated by cryo-electron microscopy. J Mol Biol 318, 121-133.

Albert MA, Dubreuil JD. Nouvelles observations appuyant le rôle de la toxine STb d'Escherichia coli dans la diarrhée chez l'Homme. (2008). In: Benoit E, Goudey-Perriere F, Marchot P, Servent D. Toxines et fonctions choloinergiques neuronales et non neuronales, Paris: Société Française pour l'Etude des Toxines. p. 101-4.

Albert, M.A., Kojic, L.D., Nabi, I.R. and Dubreuil, J.D. (2011). Cell typedependent internalization of the Escherichia coli STb enterotoxin. FEMS Immunol Med Microbiol 61, 205-217.

Alnemri, E.S., Livingston, D.J., Nicholson, D.W., Salvesen, G., Thornberry, N.A., Wong, W.W. and Yuan, J. (1996). Human ICE/CED-3 protease nomenclature. Cell 87, 171.

Arriaga, Y.L., Harville, B.A. and Dreyfus, L.A. (1995). Contribution of individual disulfide bonds to biological action of Escherichia coli heatstable enterotoxin B. Infect Immun 63, 4715-4720.

Ban, K. and Kozar, R.A. (2010). Glutamine protects against apoptosis via downregulation of Sp3 in intestinal epithelial cells. Am J Physiol Gastrointest Liver Physiol 299, G1344-1353.

Bantel, H., Sinha, B., Domschke, W., Peters, G., Schulze-Osthoff, K. and Janicke, R.U. (2001). $\alpha$-toxin is a mediator of Staphylococcus aureus- 
induced cell death and activates caspases via the intrinsic death pathway independently of death receptor signaling. J Cell Biol 155, 637-648.

Beausoleil, H.E. and Dubreuil, J.D. (2001). In vitro binding characteristics and affinity for sulfatide of Escherichia coli $\mathrm{STb}$ enterotoxin. Receptors Channels 7, 401-411.

Beausoleil, H.E., Labrie, V. and Dubreuil, J.D. (2002a). Trypan blue uptake by chinese hamster ovary cultured epithelial cells: a cellular model to study Escherichia coli STb enterotoxin. Toxicon 40, 185-191.

Beausoleil, H.E., Lepine, F. and Dubreuil, J.D. (2002b). LC-MS analysis of pig intestine sulfatides: interaction with Escherichia coli STb enterotoxin and characterization of molecular species present. FEMS Microbiol Lett 209, 183-188.

Beauvais, F., Michel, L. and Dubertret, L. (1995). Human eosinophils in culture undergo a striking and rapid shrinkage during apoptosis. Role of $\mathrm{K}^{+}$channels. J Leukoc Biol 57, 851-855.

Beem, E., Holliday, L.S. and Segal, M.S. (2004). The 1.4-MDa apoptosome is a critical intermediate in apoptosome maturation. Am J Physiol Cell Physiol 287, C664-672.

Benz, I. and Schmidt, M.A. (1989). Cloning and expression of an adhesin (AIDA-I) involved in diffuse adherence of enteropathogenic Escherichia coli. Infect Immun 57, 1506-1511. 
Benz, I. and Schmidt, M.A. (1992). Isolation and serologic characterization of AIDA-I, the adhesin mediating the diffuse adherence phenotype of the diarrhea-associated Escherichia coli strain 2787 (O126:H27). Infect Immun 60, 13-18.

Berberov, E.M., Zhou, Y., Francis, D.H., Scott, M.A., Kachman, S.D. and Moxley, R.A. (2004). Relative importance of heat-labile enterotoxin in the causation of severe diarrheal disease in the gnotobiotic piglet model by a strain of enterotoxigenic Escherichia coli that produces multiple enterotoxins. Infect Immun 72, 3914-3924.

Bhakdi, S. and Tranum-Jensen, J. (1991). $\alpha$-toxin of Staphylococcus aureus. Microbiol Rev 55, 733-751.

Black, R.A., Kronheim, S.R., Merriam, J.E., March, C.J. and Hopp, T.P. (1989). A pre-aspartate-specific protease from human leukocytes that cleaves pro-interleukin-1 beta. J Biol Chem 264, 5323-5326.

Bortner, C.D., Hughes, F.M., Jr. and Cidlowski, J.A. (1997). A primary role for $\mathrm{K}^{+}$and $\mathrm{Na}^{+}$efflux in the activation of apoptosis. J Biol Chem 272, 32436-32442.

Bouillet, P., Metcalf, D., Huang, D.C., Tarlinton, D.M., Kay, T.W., Kontgen, F., et al. (1999). Proapoptotic Bcl-2 relative Bim required for certain apoptotic responses, leukocyte homeostasis, and to preclude autoimmunity. Science 286, 1735-1738. 
Bouillet, P. and Strasser, A. (2002). BH3-only proteins - evolutionarily conserved proapoptotic Bcl-2 family members essential for initiating programmed cell death. $J$ Cell Sci 115, 1567-1574.

Boyd, J.M., Gallo, G.J., Elangovan, B., Houghton, A.B., Malstrom, S., Avery, B.J., et al. (1995). Bik, a novel death-inducing protein shares a distinct sequence motif with Bcl-2 family proteins and interacts with viral and cellular survival-promoting proteins. Oncogene 11, 1921-1928.

Brito, G.A., Fujji, J., Carneiro-Filho, B.A., Lima, A.A., Obrig, T. and Guerrant, R.L. (2002). Mechanism of Clostridium difficile toxin Ainduced apoptosis in T84 cells. J Infect Dis 186, 1438-1447.

Burgess, M.N., Bywater, R.J., Cowley, C.M., Mullan, N.A. and Newsome, P.M. (1978). Biological evaluation of a methanol-soluble, heat-stable Escherichia coli enterotoxin in infant mice, pigs, rabbits, and calves. Infect Immun 21, 526-531.

Cain, K., Langlais, C., Sun, X.M., Brown, D.G. and Cohen, G.M. (2001). Physiological concentrations of $\mathrm{K}^{+}$inhibit cytochrome c-dependent formation of the apoptosome. $J$ Biol Chem 276, 41985-41990.

Carneiro, B.A., Fujii, J., Brito, G.A., Alcantara, C., Oria, R.B., Lima, A.A., et al. (2006). Caspase and bid involvement in Clostridium difficile toxin A-induced apoptosis and modulation of toxin A effects by glutamine and alanyl-glutamine in vivo and in vitro. Infect Immun 74 81-87.

Chakrabarti, G. and McClane, B.A. (2005). The importance of calcium influx, calpain and calmodulin for the activation of $\mathrm{CaCo}-2$ cell death 
pathways by Clostridium perfringens enterotoxin. Cell Microbiol 7 129-146.

Chao, K.L. and Dreyfus, L.A. (1997). Interaction of Escherichia coli heatstable enterotoxin B with cultured human intestinal epithelial cells. Infect Immun 65, 3209-3217.

Choi, C., Cho, W., Chung, H., Jung, T., Kim, J. and Chae, C. (2001). Prevalence of the enteroaggregative Escherichia coli heat-stable enterotoxin 1 (EAST1) gene in isolates in weaned pigs with diarrhea and/or edema disease. Vet Microbiol 81, 65-71.

Choi, D.W. (1985). Glutamate neurotoxicity in cortical cell culture is calcium dependent. Neurosci Lett 58, 293-297.

Choi, D.W. (1988). Calcium-mediated neurotoxicity: relationship to specific channel types and role in ischemic damage. Trends Neurosci 11, 465469.

Clarke, P.R. and Allan, L.A. (2009). Cell-cycle control in the face of damage-a matter of life or death. Trends Cell Biol 19, 89-98.

Conradt, B. and Horvitz, H.R. (1998). The C. elegans protein EGL-1 is required for programmed cell death and interacts with the Bcl-2-like protein CED-9. Cell 93, 519-529.

Croxen, M.A. and Finlay, B.B. (2010). Molecular mechanisms of Escherichia coli pathogenicity. Nat Rev Microbiol 8, 26-38. 
Debellis, L., Diana, A., Arcidiacono, D., Fiorotto, R., Portincasa, P., Altomare, D.F., et al. (2009). The Vibrio cholerae cytolysin promotes chloride secretion from intact human intestinal mucosa. PLoS One 4, e5074.

Degterev, A. and Yuan, J. (2008) Expansion and evolution of cell death programmes. In Nat Rev Mol Cell Biol, 2008/04/17 edn., pp. 378-390.

Din, F.V., Dunlop, M.G. and Stark, L.A. (2004). Evidence for colorectal cancer cell specificity of aspirin effects on NF kappa B signalling and apoptosis. Br J Cancer 91 381-388.

Dreyfus, L.A., Harville, B., Howard, D.E., Shaban, R., Beatty, D.M. and Morris, S.J. (1993). Calcium influx mediated by the Escherichia coli heat-stable enterotoxin B (STB). Proc Natl Acad Sci U S A $903202-$ 3206.

Dreyfus, L.A., Urban, R.G., Whipp, S.C., Slaughter, C., Tachias, K. and Kupersztoch, Y.M. (1992). Purification of the STB enterotoxin of Escherichia coli and the role of selected amino acids on its secretion, stability and toxicity. Mol Microbiol 6 2397-2406.

Dubreuil, J.D. (2008). Escherichia coli STb toxin and colibacillosis: knowing is half the battle. FEMS Microbiol Lett 278, 137-145.

Dubreuil, J.D., Fairbrother, J.M., Lallier, R. and Lariviere, S. (1991). Production and purification of heat-stable enterotoxin $b$ from a porcine Escherichia coli strain. Infect Immun 59, 198-203. 
Dubreuil, J.D., Letellier, A. and Harel, J. (1996). A recombinant Escherichia coli heat-stable enterotoxin $\mathrm{b}(\mathrm{STb})$ fusion protein eliciting neutralizing antibodies. FEMS Immunol Med Microbiol 13, 317-323.

Duprez, L., Wirawan, E., Vanden Berghe, T. and Vandenabeele, P. (2009). Major cell death pathways at a glance. Microbes Infect 11 1050-1062.

Echeverria, P., Seriwatana, J., Taylor, D.N., Tirapat, C., Chaicumpa, W. and Rowe, B. (1985). Identification by DNA hybridization of enterotoxigenic Escherichia coli in a longitudinal study of villages in Thailand. J Infect Dis 151, 124-130.

Elmore, S. (2007). Apoptosis: a review of programmed cell death. Toxicol Pathol 35 495-516.

Elwell, C., Chao, K., Patel, K. and Dreyfus, L. (2001). Escherichia coli CdtB mediates cytolethal distending toxin cell cycle arrest. Infect Immun 69, 3418-3422.

Fairbrother, J.M., Nadeau, E. and Gyles, C.L. (2005). Escherichia coli in postweaning diarrhea in pigs: an update on bacterial types, pathogenesis, and prevention strategies. Anim Health Res Rev 6 17-39.

Fink, S.L. and Cookson, B.T. (2005). Apoptosis, pyroptosis, and necrosis: mechanistic description of dead and dying eukaryotic cells. Infect Immun 73 1907-1916.

Foreman, D.T., Martinez, Y., Coombs, G., Torres, A. and Kupersztoch, Y.M. (1995). TolC and DsbA are needed for the secretion of STB, a heatstable enterotoxin of Escherichia coli. Mol Microbiol 18, 237-245. 
Fujii, Y., Kondo, Y. and Okamoto, K. (1995). Involvement of prostaglandin $\mathrm{E}_{2}$ synthesis in the intestinal secretory action of Escherichia coli heatstable enterotoxin II. FEMS Microbiol Lett 130, 259-265.

Fujii, Y., Nomura, T., Yamanaka, H. and Okamoto, K. (1997). Involvement of $\mathrm{Ca}\left({ }^{2+}\right)$-calmodulin-dependent protein kinase II in the intestinal secretory action of Escherichia coli heat-stable enterotoxin II. Microbiol Immunol 41 633-636.

Gaastra, W. and Svennerholm, A.M. (1996). Colonization factors of human enterotoxigenic Escherichia coli (ETEC). Trends Microbiol 4, 444452.

Galmiche, A., Rassow, J., Doye, A., Cagnol, S., Chambard, J.C., Contamin, S., et al. (2000). The N-terminal $34 \mathrm{kDa}$ fragment of Helicobacter pylori vacuolating cytotoxin targets mitochondria and induces cytochrome c release. EMBO J 19, 6361-6370.

Garmendia, J., Frankel, G. and Crepin, V.F. (2005). Enteropathogenic and enterohemorrhagic Escherichia coli infections: translocation, translocation, translocation. Infect Immun 73, 2573-2585.

Giannella, R.A. (1995). Escherichia coli heat-stable enterotoxins, guanylins, and their receptors: what are they and what do they do? J Lab Clin Med 125, 173-181.

Goncalves, C., Berthiaume, F., Mourez, M. and Dubreuil, J.D. (2008). Escherichia coli $\mathrm{STb}$ toxin binding to sulfatide and its inhibition by carragenan. FEMS Microbiol Lett 281, 30-35. 
Goncalves, C. and Dubreuil, J.D. (2009). Effect of Escherichia coli STb toxin on NIH-3T3 cells. FEMS Immunol Med Microbiol 55 432-441.

Goncalves, C., Vachon, V., Schwartz, J.L. and Dubreuil, J.D. (2007). The Escherichia coli enterotoxin STb permeabilizes piglet jejunal brush border membrane vesicles. Infect Immun 75 2208-2213.

Gribar, S.C., Richardson, W.M., Sodhi, C.P. and Hackam, D.J. (2008). No longer an innocent bystander: epithelial toll-like receptor signaling in the development of mucosal inflammation. Mol Med 14, 645-659.

Griffiths, S.L., Finkelstein, R.A. and Critchley, D.R. (1986). Characterization of the receptor for cholera toxin and Escherichia coli heat-labile toxin in rabbit intestinal brush borders. Biochem J 238, 313-322.

Gyles, C.L. and Barnum, D.A. (1969). A heat-labile enterotoxin from strains of Eschericha coli enteropathogenic for pigs. J Infect Dis 120, 419426.

Harnett, N.M. and Gyles, C.L. (1985). Enterotoxin plasmids in bovine and porcine enterotoxigenic Escherichia coli of O groups 9, 20, 64 and 101. Can J Comp Med 49, 79-87.

Harr, M.W. and Distelhorst, C.W. (2010). Apoptosis and autophagy: decoding calcium signals that mediate life or death. Cold Spring Harb Perspect Biol 2, a005579.

Harrington, S.M., Dudley, E.G. and Nataro, J.P. (2006). Pathogenesis of enteroaggregative Escherichia coli infection. FEMS Microbiol Lett 254, 12-18. 
Harville, B.A. and Dreyfus, L.A. (1995). Involvement of 5-hydroxytryptamine and prostaglandin $\mathrm{E}_{2}$ in the intestinal secretory action of Escherichia coli heat-stable enterotoxin B. Infect Immun 63 745-750.

Haslinger, B., Strangfeld, K., Peters, G., Schulze-Osthoff, K. and Sinha, B. (2003). Staphylococcus aureus $\alpha$-toxin induces apoptosis in peripheral blood mononuclear cells: role of endogenous tumour necrosis factoralpha and the mitochondrial death pathway. Cell Microbiol 5, 729-741.

Hausmann, M. (2010). How bacteria-induced apoptosis of intestinal epithelial cells contributes to mucosal inflammation. Int J Inflam 2010, 574568.

Hengartner, M.O., Ellis, R.E. and Horvitz, H.R. (1992). Caenorhabditis elegans gene ced-9 protects cells from programmed cell death. Nature 356, 494-499.

Hengartner, M.O. and Horvitz, H.R. (1994). C. elegans cell survival gene ced9 encodes a functional homolog of the mammalian proto-oncogene bcl2. Cell 76, 665-676.

Hitotsubashi, S., Fujii, Y., Yamanaka, H. and Okamoto, K. (1992). Some properties of purified Escherichia coli heat-stable enterotoxin II. Infect Immun $604468-4474$.

Hoek, J.B., Walajtys-Rode, E. and Wang, X. (1997). Hormonal stimulation, mitochondrial $\mathrm{Ca}^{2+}$ accumulation, and the control of the mitochondrial permeability transition in intact hepatocytes. Mol Cell Biochem 174, 173-179. 
Howard, A.D., Kostura, M.J., Thornberry, N., Ding, G.J., Limjuco, G., Weidner, J., et al. (1991). IL-1-converting enzyme requires aspartic acid residues for processing of the IL-1 beta precursor at two distinct sites and does not cleave 31-kDa IL-1 alpha. J Immunol 147, 29642969.

$\mathrm{Hu}, \mathrm{S} . \mathrm{T}$. and Lee, C.H. (1988). Characterization of the transposon carrying the STII gene of enterotoxigenic Escherichia coli. Mol Gen Genet 214, 490-495.

Hu, S.T., Yang, M.K., Spandau, D.F. and Lee, C.H. (1987). Characterization of the terminal sequences flanking the transposon that carries the Escherichia coli enterotoxin STII gene. Gene 55, 157-167.

Hughes, F.M., Jr., Bortner, C.D., Purdy, G.D. and Cidlowski, J.A. (1997). Intracellular $\mathrm{K}^{+}$suppresses the activation of apoptosis in lymphocytes. J Biol Chem 272, 30567-30576.

Jackisch, C., Hahm, H.A., Tombal, B., McCloskey, D., Butash, K., Davidson, N.E. and Denmeade, S.R. (2000). Delayed micromolar elevation in intracellular calcium precedes induction of apoptosis in thapsigargintreated breast cancer cells. Clin Cancer Res 6, 2844-2850.

Jinadasa, R.N., Bloom, S.E., Weiss, R.S. and Duhamel, G.E. (2011). Cytolethal distending toxin: a conserved bacterial genotoxin that blocks cell cycle progression, leading to apoptosis of a broad range of mammalian cell lineages. Microbiology 157, 1851-1875. 
Johannes, L. and Romer, W. (2010). Shiga toxins--from cell biology to biomedical applications. Nat Rev Microbiol 8, 105-116.

Johnson, T.J. and Nolan, L.K. (2009). Pathogenomics of the virulence plasmids of Escherichia coli. Microbiol Mol Biol Rev 73, 750-774.

Jones, D.P. (2002). Redox potential of GSH/GSSG couple: assay and biological significance. Methods Enzymol 348, 93-112.

Kaper, J.B., Nataro, J.P. and Mobley, H.L. (2004). Pathogenic Escherichia coli. Nat Rev Microbiol 2 123-140.

Kerr, J.F. (1971). Shrinkage necrosis: a distinct mode of cellular death. $J$ Pathol 105, 13-20.

Kerr, J.F. (1972). Shrinkage necrosis of adrenal cortical cells. J Pathol 107, 217-219.

Kerr, J.F., Wyllie, A.H. and Currie, A.R. (1972). Apoptosis: a basic biological phenomenon with wide-ranging implications in tissue kinetics. $\mathrm{Br} J$ Cancer 26, 239-257.

Kim, J.M., Eckmann, L., Savidge, T.C., Lowe, D.C., Witthoft, T. and Kagnoff, M.F. (1998). Apoptosis of human intestinal epithelial cells after bacterial invasion. J Clin Invest 102, 1815-1823.

Kostura, M.J., Tocci, M.J., Limjuco, G., Chin, J., Cameron, P., Hillman, A.G., et al. (1989). Identification of a monocyte specific pre-interleukin 1 beta convertase activity. Proc Natl Acad Sci U S A 86, 5227-5231. 
Kuida, K., Haydar, T.F., Kuan, C.Y., Gu, Y., Taya, C., Karasuyama, H., et al. (1998). Reduced apoptosis and cytochrome c-mediated caspase activation in mice lacking caspase 9. Cell 94, 325-337.

Kuida, K., Zheng, T.S., Na, S., Kuan, C., Yang, D., Karasuyama, H., et al. (1996). Decreased apoptosis in the brain and premature lethality in CPP32-deficient mice. Nature 384, 368-372.

Kupersztoch, Y.M., Tachias, K., Moomaw, C.R., Dreyfus, L.A., Urban, R., Slaughter, C. and Whipp, S. (1990). Secretion of methanol-insoluble heat-stable enterotoxin (STB): energy- and secA-dependent conversion of pre-STB to an intermediate indistinguishable from the extracellular toxin. J Bacteriol 172 2427-2432.

Labow, B.I. and Souba, W.W. (2000). Glutamine. World J Surg 24, 15031513.

Labrie, V., Beausoleil, H.E., Harel, J. and Dubreuil, J.D. (2001a). Binding to sulfatide and enterotoxicity of various Escherichia coli STb mutants. Microbiology 147, 3141-3148.

Labrie, V., Harel, J. and Dubreuil, J.D. (2001b). Oligomerization of Escherichia coli enterotoxin b through its C-terminal hydrophobic $\alpha$ helix. Biochim Biophys Acta 1535 128-133.

Labrie, V., Harel, J. and Dubreuil, J.D. (2002). Escherichia coli heat-stable enterotoxin $\mathrm{b}(\mathrm{STb})$ in vivo internalization within rat intestinal epithelial cells. Vet Res 33, 223-228. 
Larson, S.D., Li, J., Chung, D.H. and Evers, B.M. (2007). Molecular mechanisms contributing to glutamine-mediated intestinal cell survival. Am J Physiol Gastrointest Liver Physiol 293, G1262-1271.

Lawrence, R.M., Huang, P.T., Glick, J., Oppenheim, J.D. and Maas, W.K. (1990). Expression of the cloned gene for enterotoxin STb of Escherichia coli. Infect Immun 58, 970-977.

Lee, C.H., Hu, S.T., Swiatek, P.J., Moseley, S.L., Allen, S.D. and So, M. (1985). Isolation of a novel transposon which carries the Escherichia coli enterotoxin STII gene. J Bacteriol 162, 615-620.

Lee, C.H., Moseley, S.L., Moon, H.W., Whipp, S.C., Gyles, C.L. and So, M. (1983). Characterization of the gene encoding heat-stable toxin II and preliminary molecular epidemiological studies of enterotoxigenic Escherichia coli heat-stable toxin II producers. Infect Immun 42 264268.

Lencer, W.I., Constable, C., Moe, S., Rufo, P.A., Wolf, A., Jobling, M.G., et al. (1997). Proteolytic activation of cholera toxin and Escherichia coli labile toxin by entry into host epithelial cells. Signal transduction by a protease-resistant toxin variant. J Biol Chem 272, 15562-15568.

Lin, S.H., Nishino, M., Luo, W., Aumais, J.P., Galfione, M., Kuang, J. and Yu-Lee, L.Y. (2004). Inhibition of prostate tumor growth by overexpression of NudC, a microtubule motor-associated protein. Oncogene 23, 2499-2506. 
Linden, S.K., Florin, T.H. and McGuckin, M.A. (2008). Mucin dynamics in intestinal bacterial infection. PLoS One 3, e3952.

Liu, X., Zou, H., Slaughter, C. and Wang, X. (1997). DFF, a heterodimeric protein that functions downstream of caspase-3 to trigger DNA fragmentation during apoptosis. Cell 89 175-184.

Lomonosova, E. and Chinnadurai, G. (2008). BH3-only proteins in apoptosis and beyond: an overview. Oncogene 27 Suppl 1, S2-19.

Lortie, L.A., Dubreuil, J.D. and Harel, J. (1991). Characterization of Escherichia coli strains producing heat-stable enterotoxin b (STb) isolated from humans with diarrhea. J Clin Microbiol 29, 656-659.

Lupp, C., Robertson, M.L., Wickham, M.E., Sekirov, I., Champion, O.L., Gaynor, E.C. and Finlay, B.B. (2007). Host-mediated inflammation disrupts the intestinal microbiota and promotes the overgrowth of Enterobacteriaceae. Cell Host Microbe 2, 119-129.

Maeno, E., Ishizaki, Y., Kanaseki, T., Hazama, A. and Okada, Y. (2000). Normotonic cell shrinkage because of disordered volume regulation is an early prerequisite to apoptosis. Proc Natl Acad Sci U S A 97, 94879492.

Manente, L., Perna, A., Buommino, E., Altucci, L., Lucariello, A., Citro, G., et al. (2008). The Helicobacter pylori's protein VacA has direct effects on the regulation of cell cycle and apoptosis in gastric epithelial cells. $J$ Cell Physiol 214 582-587. 
Marches, O., Ledger, T.N., Boury, M., Ohara, M., Tu, X., Goffaux, F., et al. (2003). Enteropathogenic and enterohaemorrhagic Escherichia coli deliver a novel effector called Cif, which blocks cell cycle G2/M transition. Mol Microbiol 50, 1553-1567.

Martikainen, P., Kyprianou, N., Tucker, R.W. and Isaacs, J.T. (1991). Programmed death of nonproliferating androgen-independent prostatic cancer cells. Cancer Res 51, 4693-4700.

McDonel, J.L. (1974). In Vivo Effects of Clostridium perfringens Enteropathogenic Factors on the Rat Ileum. Infect Immun 10, 11561162.

McDonnell, T.J., Deane, N., Platt, F.M., Nunez, G., Jaeger, U., McKearn, J.P. and Korsmeyer, S.J. (1989). bcl-2-immunoglobulin transgenic mice demonstrate extended $\mathrm{B}$ cell survival and follicular lymphoproliferation. Cell 57, 79-88.

McGuckin, M.A., Linden, S.K., Sutton, P. and Florin, T.H. (2011). Mucin dynamics and enteric pathogens. Nat Rev Microbiol 9, 265-278.

Morin, D., Pires, F., Plin, C. and Tillement, J.P. (2004). Role of the permeability transition pore in cytochrome $\mathrm{C}$ release from mitochondria during ischemia-reperfusion in rat liver. Biochem Pharmacol 68, 2065-2073.

Muller, A., Gunther, D., Brinkmann, V., Hurwitz, R., Meyer, T.F. and Rudel, T. (2000). Targeting of the pro-apoptotic VDAC-like porin (PorB) of 
Neisseria gonorrhoeae to mitochondria of infected cells. EMBO J 19, $5332-5343$.

Nagy, B. and Fekete, P.Z. (1999). Enterotoxigenic Escherichia coli (ETEC) in farm animals. Vet Res 30, 259-284.

Nagy, B. and Fekete, P.Z. (2005). Enterotoxigenic Escherichia coli in veterinary medicine. Int J Med Microbiol 295, 443-454.

Nataro, J.P. and Kaper, J.B. (1998). Diarrheagenic Escherichia coli. Clin Microbiol Rev 11, 142-201.

Nataro, J.P., Kaper, J.B., Robins-Browne, R., Prado, V., Vial, P. and Levine, M.M. (1987). Patterns of adherence of diarrheagenic Escherichia coli to HEp-2 cells. Pediatr Infect Dis J 6, 829-831.

Ngeleka, M., Pritchard, J., Appleyard, G., Middleton, D.M. and Fairbrother, J.M. (2003). Isolation and association of Escherichia coli AIDA-I/STb, rather than EAST1 pathotype, with diarrhea in piglets and antibiotic sensitivity of isolates. J Vet Diagn Invest 15, 242-252.

Niewerth, U., Frey, A., Voss, T., Le Bouguenec, C., Baljer, G., Franke, S. and Schmidt, M.A. (2001). The AIDA autotransporter system is associated with F18 and stx2e in Escherichia coli isolates from pigs diagnosed with edema disease and postweaning diarrhea. Clin Diagn Lab Immunol 8, 143-149.

Nottrott, S., Schoentaube, J., Genth, H., Just, I. and Gerhard, R. (2007). Clostridium difficile toxin A-induced apoptosis is p53-independent but depends on glucosylation of Rho GTPases. Apoptosis 12, 1443-1453. 
Nougayrede, J.P., Taieb, F., De Rycke, J. and Oswald, E. (2005). Cyclomodulins: bacterial effectors that modulate the eukaryotic cell cycle. Trends Microbiol 13, 103-110.

Okamoto, K., Baba, T., Yamanaka, H., Akashi, N. and Fujii, Y. (1995). Disulfide bond formation and secretion of Escherichia coli heat-stable enterotoxin II. J Bacteriol 177, 4579-4586.

Okamoto, K. and Takahara, M. (1990). Synthesis of Escherichia coli heatstable enterotoxin STp as a pre-pro form and role of the pro sequence in secretion. J Bacteriol 172, 5260-5265.

Okoh, A.I. and Osode, A.N. (2008). Enterotoxigenic Escherichia coli (ETEC): a recurring decimal in infants' and travelers' diarrhea. Rev Environ Health 23, 135-148.

Orrenius, S., Zhivotovsky, B. and Nicotera, P. (2003). Regulation of cell death: the calcium-apoptosis link. Nat Rev Mol Cell Biol 4, 552-565.

Ow, Y.P., Green, D.R., Hao, Z. and Mak, T.W. (2008). Cytochrome c: functions beyond respiration. Nat Rev Mol Cell Biol 9 532-542.

Parsot, C. (2005). Shigella spp. and enteroinvasive Escherichia coli pathogenicity factors. FEMS Microbiol Lett 252, 11-18.

Pennington, H. (2010). Escherichia coli O157. Lancet 376, 1428-1435.

Peterson, J.W. and Whipp, S.C. (1995). Comparison of the mechanisms of action of cholera toxin and the heat-stable enterotoxins of Escherichia coli. Infect Immun 63 1452-1461. 
Petronilli, V., Penzo, D., Scorrano, L., Bernardi, P. and Di Lisa, F. (2001). The mitochondrial permeability transition, release of cytochrome $\mathrm{c}$ and cell death. Correlation with the duration of pore openings in situ. $J$ Biol Chem 276, 12030-12034.

Pickett, C.L., Twiddy, E.M., Coker, C. and Holmes, R.K. (1989). Cloning, nucleotide sequence, and hybridization studies of the type IIb heatlabile enterotoxin gene of Escherichia coli. J Bacteriol 171, 49454952.

Pickett, C.L., Weinstein, D.L. and Holmes, R.K. (1987). Genetics of type IIa heat-labile enterotoxin of Escherichia coli: operon fusions, nucleotide sequence, and hybridization studies. J Bacteriol 169, 5180-5187.

Qadri, F., Svennerholm, A.M., Faruque, A.S. and Sack, R.B. (2005). Enterotoxigenic Escherichia coli in developing countries: epidemiology, microbiology, clinical features, treatment, and prevention. Clin Microbiol Rev 18, 465-483.

Rappuoli, R., Pizza, M., Douce, G. and Dougan, G. (1999). Structure and mucosal adjuvanticity of cholera and Escherichia coli heat-labile enterotoxins. Immunol Today 20, 493-500.

Rasheed, J.K., Guzman-Verduzco, L.M. and Kupersztoch, Y.M. (1990). Two precursors of the heat-stable enterotoxin of Escherichia coli: evidence of extracellular processing. Mol Microbiol 4, 265-273.

Ravi, M., Ngeleka, M., Kim, S.H., Gyles, C., Berthiaume, F., Mourez, M., et al. (2007). Contribution of AIDA-I to the pathogenicity of a porcine 
diarrheagenic Escherichia coli and to intestinal colonization through biofilm formation in pigs. Vet Microbiol 120, 308-319.

Remillard, C.V. and Yuan, J.X. (2004). Activation of $\mathrm{K}^{+}$channels: an essential pathway in programmed cell death. Am J Physiol Lung Cell Mol Physiol 286, L49-67.

Rizzuto, R. and Pozzan, T. (2006). Microdomains of intracellular $\mathrm{Ca}^{2+}$ : molecular determinants and functional consequences. Physiol Rev 86, $369-408$.

Rose, R., Whipp, S.C. and Moon, H.W. (1987). Effects of Escherichia coli heat-stable enterotoxin $\mathrm{b}$ on small intestinal villi in pigs, rabbits, and lambs. Vet Pathol 24 71-79.

Roth, E., Oehler, R., Manhart, N., Exner, R., Wessner, B., Strasser, E. and Spittler, A. (2002). Regulative potential of glutamine--relation to glutathione metabolism. Nutrition 18, 217-221.

Roth, E., Spittler, A. and Oehler, R. (1996). [Glutamine: effects on the immune system, protein balance and intestinal functions]. Wien Klin Wochenschr 108, 669-676.

Rousset, E. and Dubreuil, J.D. (1999). Evidence that Escherichia coli STb enterotoxin binds to lipidic components extracted from the pig jejunal mucosa. Toxicon 37, 1529-1537.

Rousset, E., Harel, J. and Dubreuil, J.D. (1998a). Binding characteristics of Escherichia coli enterotoxin b (STb) to the pig jejunum and partial characterization of the molecule involved. Microb Pathog 24 277-288. 
Rousset, E., Harel, J. and Dubreuil, J.D. (1998b). Sulfatide from the pig jejunum brush border epithelial cell surface is involved in binding of Escherichia coli enterotoxin b. Infect Immun 66, 5650-5658.

Rudel, T., Kepp, O. and Kozjak-Pavlovic, V. (2010). Interactions between bacterial pathogens and mitochondrial cell death pathways. Nat Rev Microbiol 8 693-705.

Saka, H.A., Bidinost, C., Sola, C., Carranza, P., Collino, C., Ortiz, S., et al. (2008). Vibrio cholerae cytolysin is essential for high enterotoxicity and apoptosis induction produced by a cholera toxin gene-negative $V$. cholerae non-O1, non-O139 strain. Microb Pathog 44, 118-128.

Samba-Louaka, A., Nougayrede, J.P., Watrin, C., Oswald, E. and Taieb, F. (2009). The enteropathogenic Escherichia coli effector Cif induces delayed apoptosis in epithelial cells. Infect Immun 77, 5471-5477.

Sattler, M., Liang, H., Nettesheim, D., Meadows, R.P., Harlan, J.E., Eberstadt, M., et al. (1997). Structure of Bcl-xL-Bak peptide complex: recognition between regulators of apoptosis. Science 275, 983-986.

Saunders, J.W., Jr. (1966). Death in embryonic systems. Science 154, 604-612.

Savarino, S.J., Fasano, A., Robertson, D.C. and Levine, M.M. (1991). Enteroaggregative Escherichia coli elaborate a heat-stable enterotoxin demonstrable in an in vitro rabbit intestinal model. $J$ Clin Invest $\mathbf{8 7}$, $1450-1455$.

Savarino, S.J., Fasano, A., Watson, J., Martin, B.M., Levine, M.M., Guandalini, S. and Guerry, P. (1993). Enteroaggregative Escherichia 
coli heat-stable enterotoxin 1 represents another subfamily of E. coli heat-stable toxin. Proc Natl Acad Sci U S A 90, 3093-3097.

Schmidt, M.A. (2010). LEEways: tales of EPEC, ATEC and EHEC. Cell Microbiol 12, 1544-1552.

Schwab, B.L., Guerini, D., Didszun, C., Bano, D., Ferrando-May, E., Fava, E., et al. (2002). Cleavage of plasma membrane calcium pumps by caspases: a link between apoptosis and necrosis. Cell Death Differ 9 818-831.

Sears, C.L. and Kaper, J.B. (1996). Enteric bacterial toxins: mechanisms of action and linkage to intestinal secretion. Microbiol Rev 60, 167-215.

Servin, A.L. (2005). Pathogenesis of Afa/Dr diffusely adhering Escherichia coli. Clin Microbiol Rev 18, 264-292.

Sixma, T.K., Kalk, K.H., van Zanten, B.A., Dauter, Z., Kingma, J., Witholt, B. and Hol, W.G. (1993). Refined structure of Escherichia coli heat-labile enterotoxin, a close relative of cholera toxin. J Mol Biol 230, 890-918.

Sixma, T.K., Pronk, S.E., Kalk, K.H., Wartna, E.S., van Zanten, B.A., Witholt, B. and Hol, W.G. (1991). Crystal structure of a cholera toxin-related heat-labile enterotoxin from E. coli. Nature 351, 371-377.

So, M. and McCarthy, B.J. (1980). Nucleotide sequence of the bacterial transposon Tn1681 encoding a heat-stable (ST) toxin and its identification in enterotoxigenic Escherichia coli strains. Proc Natl Acad Sci U S A 77, 4011-4015. 
Spandau, D.F. and Lee, C.H. (1987). Determination of the promoter strength of the gene encoding Escherichia coli heat-stable enterotoxin II. $J$ Bacteriol 169, 1740-1744.

Spangler, B.D. (1992). Structure and function of cholera toxin and the related Escherichia coli heat-labile enterotoxin. Microbiol Rev 56, 622-647.

Stecher, B. and Hardt, W.D. (2011). Mechanisms controlling pathogen colonization of the gut. Curr Opin Microbiol 14, 82-91.

Sukumar, M., Rizo, J., Wall, M., Dreyfus, L.A., Kupersztoch, Y.M. and Gierasch, L.M. (1995). The structure of Escherichia coli heat-stable enterotoxin $b$ by nuclear magnetic resonance and circular dichroism. Protein Sci 4 1718-1729.

Szabo, I., Lepple-Wienhues, A., Kaba, K.N., Zoratti, M., Gulbins, E. and Lang, F. (1998). Tyrosine kinase-dependent activation of a chloride channel in CD95-induced apoptosis in T lymphocytes. Proc Natl Acad Sci U S A 95, 6169-6174.

Tamayo, E., Merino, R., Gonzalez-Rojas, J., Marquina, R., Santiuste, I., Amado, J.A., et al. (2005). The Escherichia coli heat-labile enterotoxin induces apoptosis of immature lymphocytes in vivo via a glucocorticoid-dependent pathway. Eur J Immunol 35, 3505-3515.

Tamayo, E., Postigo, J., Del Giudice, G., Rappuoli, R., Benito, A., Yagita, H., et al. (2009). Involvement of the intrinsic and extrinsic cell-death pathways in the induction of apoptosis of mature lymphocytes by the Escherichia coli heat-labile enterotoxin. Eur J Immunol 39 439-446. 
Thornberry, N.A., Bull, H.G., Calaycay, J.R., Chapman, K.T., Howard, A.D., Kostura, M.J., et al. (1992). A novel heterodimeric cysteine protease is required for interleukin-1 beta processing in monocytes. Nature 356, 768-774.

Thornberry, N.A., Rano, T.A., Peterson, E.P., Rasper, D.M., Timkey, T., Garcia-Calvo, M., et al. (1997). A combinatorial approach defines specificities of members of the caspase family and granzyme B. Functional relationships established for key mediators of apoptosis. $J$ Biol Chem 272, 17907-17911.

Trump, B.F., Goldblatt, P.J. and Stowell, R.E. (1965). Studies on Necrosis of Mouse Liver in vitro. Ultrastructural Alterations in the Mitochondria of Hepatic Parenchymal Cells. Lab Invest 14, 343-371.

Tsuji, T., Honda, T., Miwatani, T., Wakabayashi, S. and Matsubara, H. (1985). Analysis of receptor-binding site in Escherichia coli enterotoxin. $J$ Biol Chem 260, 8552-8558.

Tsujimoto, Y., Cossman, J., Jaffe, E. and Croce, C.M. (1985). Involvement of the bcl-2 gene in human follicular lymphoma. Science 228, 1440-1443.

Turner, S.M., Scott-Tucker, A., Cooper, L.M. and Henderson, I.R. (2006). Weapons of mass destruction: virulence factors of the global killer enterotoxigenic Escherichia coli. FEMS Microbiol Lett 263, 10-20.

Urban, R.G., Pipper, E.M., Dreyfus, L.A. and Whipp, S.C. (1990). High-level production of Escherichia coli $\mathrm{STb}$ heat-stable enterotoxin and 
quantification by a direct enzyme-linked immunosorbent assay. J Clin Microbiol 28, 2383-2388.

Vaandrager, A.B. (2002). Structure and function of the heat-stable enterotoxin receptor/guanylyl cyclase C. Mol Cell Biochem 230, 73-83.

Varfolomeev, E.E., Schuchmann, M., Luria, V., Chiannilkulchai, N., Beckmann, J.S., Mett, I.L., et al. (1998). Targeted disruption of the mouse Caspase 8 gene ablates cell death induction by the TNF receptors, Fas/Apo1, and DR3 and is lethal prenatally. Immunity 9, $267-276$

Vaux, D.L., Cory, S. and Adams, J.M. (1988). Bcl-2 gene promotes haemopoietic cell survival and cooperates with c-myc to immortalize pre-B cells. Nature 335, 440-442.

Veilleux, S. and Dubreuil, J.D. (2006). Presence of Escherichia coli carrying the EAST1 toxin gene in farm animals. Vet Res 37, 3-13.

Whipp, S.C. (1990). Assay for enterotoxigenic Escherichia coli heat-stable toxin b in rats and mice. Infect Immun 58, 930-934.

Whipp, S.C., Kokue, E., Morgan, R.W., Rose, R. and Moon, H.W. (1987). Functional significance of histologic alterations induced by Escherichia coli pig-specific, mouse-negative, heat-stable enterotoxin (STb). Vet Res Commun 11 41-55.

Whipp, S.C., Moseley, S.L. and Moon, H.W. (1986). Microscopic alterations in jejunal epithelium of 3-week-old pigs induced by pig-specific, 
mouse-negative, heat-stable Escherichia coli enterotoxin. Am J Vet Res 47 615-618.

Wolfenden, R. (1969). Transition state analogues for enzyme catalysis. Nature 223, 704-705.

Yin, X.M., Wang, K., Gross, A., Zhao, Y., Zinkel, S., Klocke, B., et al. (1999). Bid-deficient mice are resistant to Fas-induced hepatocellular apoptosis. Nature 400, 886-891.

Youle, R.J. and Strasser, A. (2008). The BCL-2 protein family: opposing activities that mediate cell death. Nat Rev Mol Cell Biol 9 47-59.

Yuan, J. and Horvitz, H.R. (1992). The Caenorhabditis elegans cell death gene ced-4 encodes a novel protein and is expressed during the period of extensive programmed cell death. Development 116, 309-320.

Yuan, J., Shaham, S., Ledoux, S., Ellis, H.M. and Horvitz, H.R. (1993). The $C$. elegans cell death gene ced-3 encodes a protein similar to mammalian interleukin-1 beta-converting enzyme. Cell 75, 641-652.

Zha, H., Aime-Sempe, C., Sato, T. and Reed, J.C. (1996). Proapoptotic protein Bax heterodimerizes with Bcl-2 and homodimerizes with Bax via a novel domain (BH3) distinct from $\mathrm{BH} 1$ and $\mathrm{BH} 2 . J$ Biol Chem 271, $7440-7444$.

Zhang, W., Berberov, E.M., Freeling, J., He, D., Moxley, R.A. and Francis, D.H. (2006). Significance of heat-stable and heat-labile enterotoxins in porcine colibacillosis in an additive model for pathogenicity studies. Infect Immun 74, 3107-3114. 
http://www.ecl-lab.ca/en/ecoli/pathogenesis.asp\#etec 